\title{
Combined effects of water chemistry, canopy cover, and stream size on benthic macroinvertebrates along a Central Appalachian stream continuum
}

Jesse Adam Bopp

West Virginia University

Follow this and additional works at: https://researchrepository.wvu.edu/etd

\section{Recommended Citation}

Bopp, Jesse Adam, "Combined effects of water chemistry, canopy cover, and stream size on benthic macroinvertebrates along a Central Appalachian stream continuum" (2002). Graduate Theses, Dissertations, and Problem Reports. 1537.

https://researchrepository.wvu.edu/etd/1537

This Thesis is protected by copyright and/or related rights. It has been brought to you by the The Research Repository @ WVU with permission from the rights-holder(s). You are free to use this Thesis in any way that is permitted by the copyright and related rights legislation that applies to your use. For other uses you must obtain permission from the rights-holder(s) directly, unless additional rights are indicated by a Creative Commons license in the record and/ or on the work itself. This Thesis has been accepted for inclusion in WVU Graduate Theses, Dissertations, and Problem Reports collection by an authorized administrator of The Research Repository @ WVU. For more information, please contact researchrepository@mail.wvu.edu. 
Combined effects of water chemistry, canopy cover, and stream size on benthic macroinvertebrates along a Central Appalachian stream continuum

by

Jesse A. Bopp

A THESIS
Submitted to the Davis College of Agriculture, Forestry, and Consumer Sciences
at
West Virginia University
in partial fulfillment of the requirements
for the degree of
Master of Science
in
Wildlife and Fisheries Resources
J. Todd Petty, Chairperson
Patricia M. Mazik
Janet Clayton
Kyle J. Hartman

Keywords: acidity, alkalinity, Appalachian, benthic, canopy, function, macroinvertebrate, river continuum, stream size, structure 


\begin{abstract}
Combined effects of water chemistry, canopy cover, and stream size on benthic macroinvertebrates along a Central Appalachian stream continuum
\end{abstract}

\title{
Jesse Adam Bopp
}

I sampled benthic macroinvertebrates along a $25.2 \mathrm{~km}$ stream continuum (flow 0.01 to $2.36 \mathrm{~m}^{3} \mathrm{~s}^{-1}$ ) in the Central Appalachian Mountains of West Virginia from May - October 2000. Six components of macroinvertebrate structure and function were measured: density, biomass, richness, metric composition, community taxa similarity, and feeding group composition. I quantified these components to determine if general changes in macroinvertebrate communities associated with stream size were significantly altered by reach-scale variation in water chemistry and light. I specifically determined how sitespecific variation in alkalinity and canopy cover would modify the predictions of: (1) an increase in density, biomass, and richness with increasing stream size; (2) a decrease in community taxa similarity as distance between two sites increased; and (3) a shift in the percent and absolute biomass of feeding group composition as energy inputs shift from riparian leaf litter to instream algal growth. Site-specific changes in alkalinity and canopy cover significantly affected macroinvertebrate structure and function and modified stream continuum predictions. Results indicated that alkalinity was the primary determinant of macroinvertebreate structure and function, and that the effects of canopy cover and stream size were secondary and tertiary determinants, respectively. General findings were as follows: (1) alkalinity and canopy cover determined macroinvertebrate density, biomass, and metric composition along the continuum; (2) alkalinity and basin area determined family richness patterns; (3) basin area determined community similarity with local variation from alkalinity and canopy cover; and (4) alkalinity and canopy cover determined the percent biomass of feeding group composition whereas canopy cover and basin area determined the absolute biomass of feeding group composition. Evaluation of these results suggests that small-scale variation in the geology and riparian character of Central Appalachian watersheds can modify stream continuum predictions at a continuum-specific level. 


\section{DEDICATION}

I dedicate the efforts herein to my family whose love, support, and laughter is ingrained within the pages of this document.

"People hand in hand

Have I lived to see the milk and honey land?

Where hate's a dream and love forever stands

Or is this a vision in my mind"

- Stevie Wonder, Innervisions 


\section{ACKNOWLEDGMENTS}

I sincerely thank all committee members for their suggestions during the development, collection, analyses, and writing of this research. A special thanks is given to Todd Petty for mentoring a former terrestrial wildlifer through a stream ecology project. Of course, this project would not have been possible without funding from the West Virginia Division of Natural Resources, the Biological Resources Division of the United States Geological Survey, and the United States Fish and Wildlife Service. Finally, I wish to thank: Ryan Gaujot, Peter Lamothe, Dan Nulph, Brock Reggi, and Matt Varner for field assistance; Donna Hartman, Mike Kaller, Adam Kane, and Matt Kraycar for laboratory assistance; and Jason Freund and John Sweka for statistical assistance. Because if it truly were not for appearances such as the likes of "Danbo", the "Rail Fans", the "Ghost Gobbler", my "Private Tecky", the "Second Fork Iron Chefs", and the "Laboratory Groovers", I do not know if I would have kept sane. So thanks folks, as it was an honor to laugh, learn, and party with you all. 
Table of Contents

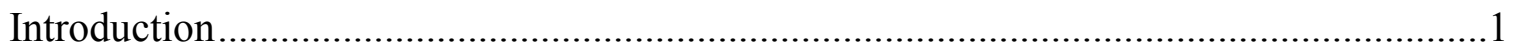

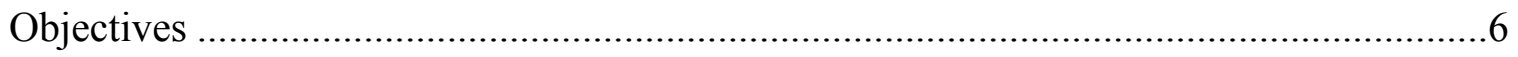

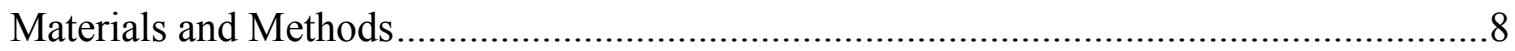

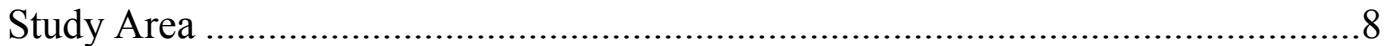

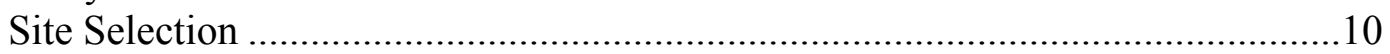

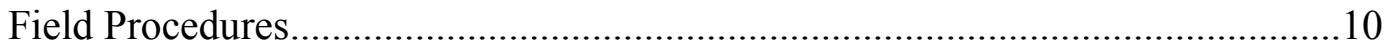

Laboratory Procedures .............................................................................. 13

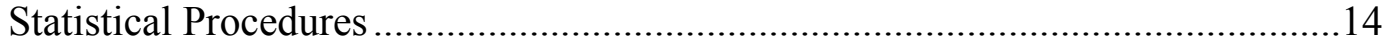

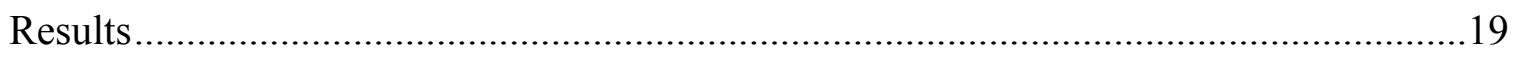

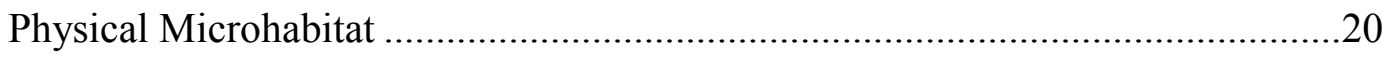

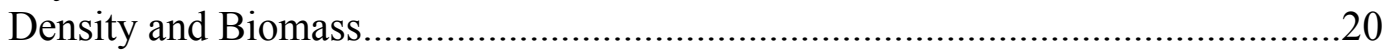

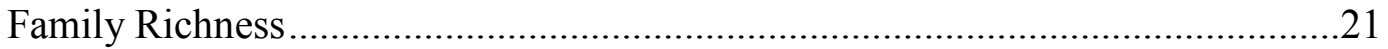

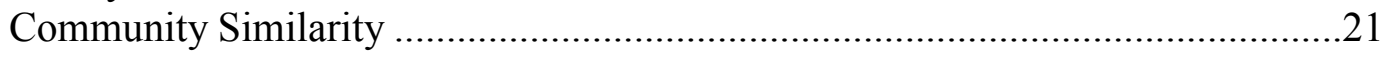

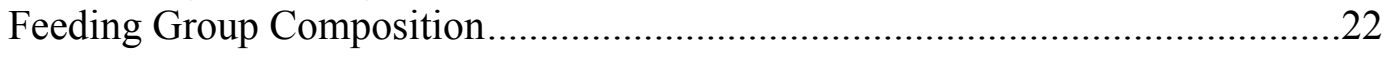

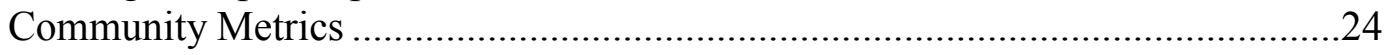

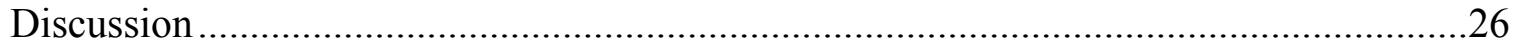

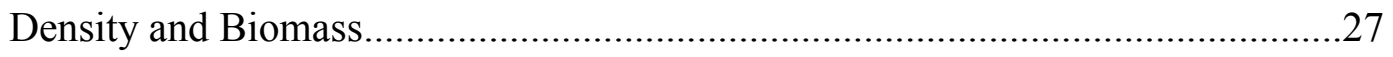

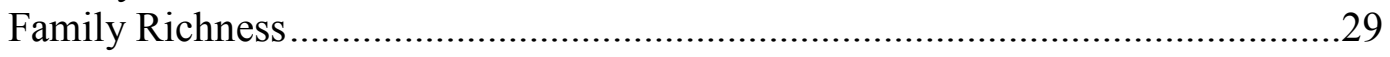

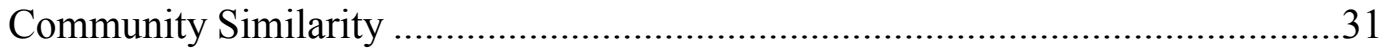

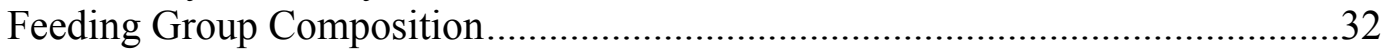

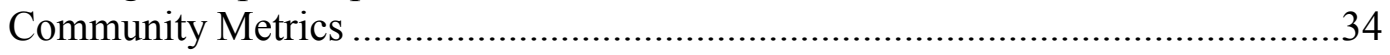

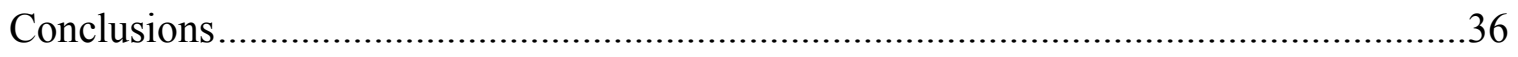

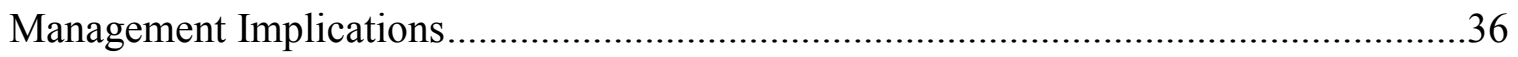

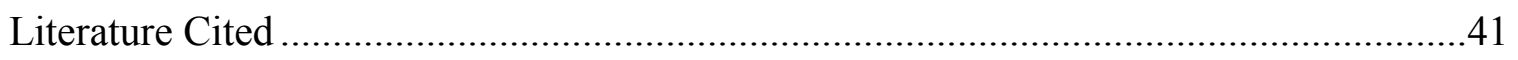


List of Tables

Table 1. Macroinvertebrate sampling sites and corresponding values for physical and chemical parameters along a $25.2 \mathrm{~km}$ continuum of the Upper Shavers Fork, WV, May - October, 2000

Table 2. Response of macroinvertebrate density and biomass to the effects of alkalinity, canopy cover, and basin area along a $25.2 \mathrm{~km}$ continuum of the Upper Shavers Fork, WV, May - October, 2000

Table 3. Response of macroinvertebrate family richness to the effects of alkalinity, canopy cover, and basin area along a $25.2 \mathrm{~km}$ continuum of the Upper Shavers Fork, WV, May - October, 2000

Table 4. Response of percent biomass of feeding groups to the effects of alkalinity, canopy cover, and basin area along a $25.2 \mathrm{~km}$ continuum of the Upper Shavers Fork, WV, May - October, 2000

Table 5. Contribution of individual families to the percent biomass of feeding group composition along a $25.2 \mathrm{~km}$ continuum of the Upper Shavers Fork, WV, May October, 2000

Table 6. Response of absolute biomass of feeding groups to the effects of alkalinity, canopy cover, and basin area along a $25.2 \mathrm{~km}$ continuum of the Upper Shavers Fork, WV, May - October, 2000.

Table 7. Annualized abundance of taxa in sites having the largest variation in alkalinity, canopy cover, and basin area along a $25.2 \mathrm{~km}$ continuum of the Upper Shavers Fork, WV, May - October, 2000.

Table 8. Comparison of the abundance of acid-sensitive taxa occurring in four headwater sites differing in alkalinity in the Upper Shavers Fork, WV, May - October 2000 


\section{List of Figures}

Figure 1. The river continuum concept with predicted changes in stream ecosystem communities along a hypothetical longitudinal gradient (From Vannote et al., 1980)

Figure 2. Hydrogen ion wet deposition across the Unites States, 2000. (From NADP, 2000)

Figure 3. The Shavers Fork watershed with the Upper Shavers Fork subsection, WV, 2000

Figure 4. The Upper Shavers Fork watershed with sampling sites along a $25.2 \mathrm{~km}$ stream size continuum, WV, May - October 2000

Figure 5. Relationship between basin area, canopy cover, and alkalinity along a $25.2 \mathrm{~km}$ continuum of the Upper Shavers Fork, WV, May - October, 2000

Figure 6. Mean density of benthic macroinvertebrates along a $25.2 \mathrm{~km}$ continuum of the Upper Shavers Fork, WV, May - October, 2000 .68

Figure 7. Mean biomass of benthic macroinvertebrates along a $25.2 \mathrm{~km}$ continuum of the Upper Shavers Fork, WV, May - October, 2000

Figure 8. Annualized mean density and biomass of benthic macroinvertebrates along a $25.2 \mathrm{~km}$ continuum of the Upper Shavers Fork, WV, May - October, 2000.........70

Figure 9. Annualized mean macroinvertebrate family richness along a $25.2 \mathrm{~km}$ continuum of the Upper Shavers Fork, WV, May - October, 2000

Figure 10. Annualized Jaccard coefficients for sites I, III, VI, VIII, and X along a 25.2 $\mathrm{km}$ continuum of the Upper Shavers Fork, WV, May - October, 2000.................72

Figure 11. Abundance of Ephemeroptera, Plecoptera, and Trichoptera along $25.2 \mathrm{~km}$ continuum of the Upper Shavers Fork, WV, May - October, 2000

Figure 12. Abundance of Leptophlebiidae to Ephemeroptera along a $25.2 \mathrm{~km}$ continuum of the Upper Shavers Fork, WV, May - October, 2000

Figure 13. Abundance of Parapsyche spp. to Hydropsychidae along a $25.2 \mathrm{~km}$ continuum of the Upper Shavers Fork, WV, May - October, 2000

Figure 14. Abundance of Eurylophella spp. to Ephemerellidae along $25.2 \mathrm{~km}$ continuum of the Upper Shavers Fork, WV, May - October, 2000 .76

Figure 15. Abundance of Epeorus spp. to Heptageniidae along a $25.2 \mathrm{~km}$ continuum of the Upper Shavers Fork, WV, May - October, 2000. 
List of Appendices

Appendix I. Macroinvertebrate orders and families collected along $25.2 \mathrm{~km}$ continuum of the Upper Shavers Fork, WV, May - October, 2000

Appendix II. Contribution of individual families to feeding group biomass in the Upper

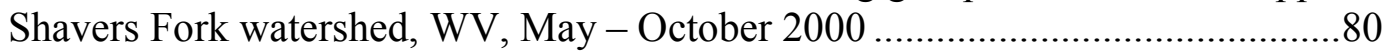




\section{Introduction}

The River Continuum Concept (RCC) is a working hypothesis that attempts to describe the spatial and temporal variation in stream ecosystem structure and function (Cushing, 1994). The RCC focuses on changes in energy inputs (i.e. allochthonous versus autochthonous) and aquatic metabolism (i.e. ratio of gross primary productivity to community respiration) with movement from small headwater streams to large basin area rivers (Vannote et al., 1980). For example, the ratio of productivity to respiration should be $<1$ in headwater reaches and $>1$ in downstream reaches due to an increase in light and gross primary productivity (GPP). The RCC also makes explicit predictions of how the benthic macroinvertebrate community, which is comprised of primary and secondary consumers, should change along a stream continuum (Figure 1). Specific predictions for macroinvertebrate communities are as follows: (1) shredders and gatherers should dominate percent $(\%)$ biomass composition in $1^{\text {st }}-2^{\text {nd }}$ order streams; (2) grazers, gatherers, and filterers should dominate $\%$ biomass composition in $3^{\text {rd }}-5^{\text {th }}$ order streams; (3) gatherers and filterers should dominate $\%$ biomass composition in $6^{\text {th }}$ or higher order streams; and (4) \% biomass composition of predators should remain relatively unchanged as stream size increases.

The RCC advanced stream ecosystem theory by providing a holistic outline for the testing of physical, chemical, and biological variables along a continuum (Minshall et al., 1985; Cushing, 1994). Yet immediately following publication, the RCC was criticized as being too general for most riverine ecosystems. For example, Winterbourne et al. (1981) contended that New Zealand streams do not experience a similar seasonality and 
temporal succession of taxa as do North American streams. Indeed, when several of the original authors conducted a large-scale North American test of several RCC predictions, their results determined that temporal variability and variability among regions often overwhelmed many observable changes along a stream continuum (Minshall et al., 1983). In particular, departures from RCC predictions occurred as a result of: (1) watershed elevation, latitude, and geography; (2) riparian condition; (3) tributary confluences; and (4) localized lithology and channel morhphology. Consequently, their findings questioned the ability of the RCC to explain patterns in the structure and function of many stream continua.

Since that time other researchers observed numerous deviations and proposed refinements. Hawkins et al. (1982) found that open canopy headwater conditions indiscriminately increased the abundance of all feeding groups, not just grazers. Bruns et al. (1984) assessed tributary effects and concluded that downstream of small tributaries functional composition approximated large stream reaches, while downstream of large tributaries functional composition approximated small stream reaches. Minshall et al. (1985) discussed how channel dredging, dams, and industry-related thermal inputs shifted, obscured, or eliminated expected responses. Statzner and Higler (1985) suggested that removing the postulates regarding: (1) continual downstream increases in kinetic (i.e. moving) energy; (2) seasonally induced species replacement; (3) absence of instream successional events; and (4) greatest variation in temperature, flow, and habitat type of mid-order reaches, would result in a more flexible application of the RCC. They contended that removing these postulates would reduce criticism yet still allow the testing of predictions concerning GPP, community respiration, organic matter processing, and 
structural and functional composition. Others suggested that a reach-level perspective based on local channel morphology is necessary to compliment entire longitudinal patterns (Brussock and Brown, 1991), since overall functional composition results from the relative contribution of each habitat type to total stream area (Huryn and Wallace, 1987). Meyer and Edwards (1990) determined that a south temperate, low gradient, blackwater river having extensive floodplain connectedness contained communities that were increasingly dependent upon allochthonous organic matter as stream size increased, despite concomitant increases in GPP in the central stream channel.

Concurrent to these modifications and refinements, several studies provided support for RCC predictions. In Oregon, Naiman and Sedell (1980) found that production to respiration ratios supported the postulate of a downstream increase in GPP. Also in Oregon, Hawkins and Sedell (1981) substantiated the hypothesis that functional group composition varies predictably along a stream continuum. Shredders dominated shaded upper reaches, scrapers peaked in mid-order reaches, gatherers and filterers increased downstream, and predator abundance remained relatively constant along a $1^{\text {st }}-7^{\text {th }}$ order continuum. In a boreal watershed of eastern Quebec, Canada, Naiman (1983) reported a production to respiration ratio of $<1$ in $1^{\text {st }}$ order reaches and $>4$ in $9^{\text {th }}$ order reaches. Indeed, streams of $4^{\text {th }}$ or higher order comprised $<13 \%$ of the watershed, but produced $>$ 86\% of the GPP. In southern Appalachian streams, Huryn and Wallace (1987) observed that functional group composition reflected the dominance of allochthonous energy inputs, an RCC expectation for forested headwater streams. Grubaugh et al. (1996) also concluded that, along a $65 \mathrm{~km}$ southern Appalachian stream gradient, the \% biomass of functional group composition conformed to RCC predictions. More recently, Carpenter 
(2000) demonstrated that a 77,000 ha continuum in western West Virginia and Pennsylvania compared closely to predictions for productivity/ respiration and macroinvertebrate community structure and function, and that outliers were explained through physical, chemical or ecological alterations linked to human influences.

Acid precipitation represents one such example of a human influence upon stream ecosystem communities. Potential impacts of stream acidification include a decrease in organic matter decomposition (Burton et al., 1985; Kimmel et al., 1985), a resulting decrease in sediment-nutrient exchange due to organic matter layering, an increase in acid-tolerant fungal growth (Wright et al., 1975), and a decrease in macroinvertebrate (e.g. Simpson et al., 1985) and fish (Lacroix, 1989; Carline et al., 1992; Fiss and Carline, 1993; Gagen et al., 1993; Marschall and Crowder, 1996; Kwak and Waters, 1997; Clayton et al., 1998) structure and function. The onsets of such impacts vary and depend upon the acute severity or chronic duration of $\mathrm{pH}$ reductions, as well as the buffering potential of the system; however, ecosystem alterations generally begin at a stream $\mathrm{pH}$ of 5.0 (Allan, 1995).

Given that acid precipitation occurs over much of the eastern United States (NADP, 2000) (Figure 2), numerous studies have described the effects of acidification on macroinvertebrate communities (Hall et al., 1982; Kimmel et al., 1985; Miller, 1985; Simpson et al., 1985; Hall and Ide, 1987; Feldman and Connor, 1992; Rosemond et al., 1992; Kobuszewski and Perry, 1993; Clayton and Menendez, 1996; Madarish and Kimmel, 1999). In particular, because effects on water chemistry are most severe in low order streams, the structure and function of headwater communities have received most of the attention. Withstanding variation in methodology (i.e. qualitative kicknet versus 
quantitative Surber and Hess collection, or sample and mesh size), acidification has been shown to consistently decrease macroinvertebrate biomass (Miller, 1985), production (Groom and Hildrew, 1989), species richness (Kimmel et al., 1985), evenness (Simpson et al., 1985), habit (Allard and Moreau, 1987), and feeding group composition (Rosemond et al., 1992). In contrast, density may be unaltered (Kobuszewski and Perry, 1993; Clarke and Scruton, 1997) or increase (Madarish and Kimmel, 1999) due to an increased abundance of acid-tolerant taxa. Indeed, taxa response to acidity is highly variable with particular orders (e.g. decrease of Ephemeroptera), families (e.g. increase of Rhyacophilidae:Trichoptera), genera (e.g. increase of Leuctra spp:Plecoptera), and species (e.g. increase of Ameletus lineatus:Ephemeroptera) exhibiting differential growth and survivorship (Bell, 1971; Simpson et al., 1985; Peterson and Eeckhaute, 1991; Rosemond et al., 1992).

In addition to descriptive studies, experimental research suggests that acidification negatively affects both macroinvertebrate physiology (Allard and Moreau, 1987; Hopkins et al., 1989; Kiffney and Clements, 1996) and organic matter processing (Burton et al., 1985; Kimmel et al., 1985; Groom and Hildrew, 1989). Increased concentrations of hydrogen ions catalyze the extraction of heavy metal precipitant. In particular, acidification increases aluminum, calcium, magnesium, potassium, manganese, iron, and cadmium (Hall et al., 1980), and significant, positive correlations between acute ( $8 \mathrm{~d}) \mathrm{pH}$ reductions (5.8 - 6.4 to $3.2-4.8$ ), and inorganic monomeric $\mathrm{Al}$ and $\mathrm{Ca}$ concentrations are reported (Hall, 1990). Furthermore, elevated concentrations occur during high discharge events (Madarish and Kimmel, 1999) and with progression downstream (Hall et al., 1980). Direct physiological effects include improper ion regulation, respiration, and 
acid/base balance (Havas, 1981; Hermann and Andersson, 1986; Rowe et al., 1989; Rockwood et al., 1990), with epi-benthic, external gill, emerging/immature, and comparatively small-sized macroinvertebrates primarily expressing higher sensitivity (Bell, 1971; Hall et al., 1980; Allan and Burton, 1986; Allard and Moreau, 1987; Hopkins et al., 1989; Kiffney and Clements; 1996). Delayed indirect effects include a reduction in the quality and processing of organic matter. Allochthonous matter is central to macroinvertebrate feeding and nutrition (Egglishaw, 1968; Minshall et al., 1983; Huryn and Wallace, 1987), and acidification slows decomposition via reductions in microbial activity and macroinvertebrate colonization (Burton et al., 1985; Kimmel et al., 1985; Garden and Davies, 1989). Individuals inhabiting such conditions exhibit hindered development, biomass, and fecundity (Soderstrom, 1988; Groom and Hildrew, 1989; Schell and Kerekes, 1989).

\section{Objectives}

Despite considerable efforts to test predictions of the RCC and to quantify the effects of acidification on stream macroinvertebrates, to my knowledge, no studies in this region have attempted to investigate the simultaneous effects of these processes on macroinvertebrates at a watershed scale. Thus my overall objective was to quantify the spatial and temporal variation in macroinvertebrate structure and function along a stream continuum in the Upper Shavers Fork watershed. I specifically quantified macroinvertebrate density, biomass, richness, relative abundance, among-site community taxa similarity, and feeding group composition.

The first objective was to compare observed patterns with those predicted by the RCC and its subsequent modifications. However, I did not measure energy inputs, 
primary production, or community respiration, rather I used RCC predictions for macroinvertebrate structure and function as a guiding framework for sampling and analyses. The second objective was to examine how reach-to-reach variability in water chemistry and canopy cover, not correlated to position along the continuum, influenced macroinvertebrate structure and function. Here, I intended to determine if general changes in macroinvertebrate communities associated with stream size were overwhelmed by small-scale changes in alkalinity or light.

Finally, my objectives are embedded within a larger, integrated study of aquatic ecosystem processes in the Upper shavers Fork watershed. The ultimate objective of the larger study is to identify factors potentially limiting biological productivity in this historically important watershed. Research herein will provide an indication of how water chemistry, canopy cover, and stream size affect macroinvertebrate communities. Furthermore, macroinvertebrate dynamics, along with physical habitat variables, influence the distribution patterns (Schlosser and Angermeier, 1995; Petty and Grossman, 1996) and productivity of fish communities (Elliot, 1976; Fausch, 1984; Hughes and Dill, 1990; Facey and Grossman, 1992; Hill and Grossman, 1993; Baker and Coon, 1997; Hughes, 1998; Nislow, 1999). Consequently, an understanding of the factors influencing macroinvertebrates may contribute to an understanding of the role that food availability has in limiting fish productivity at a watershed scale. 


\section{Materials and Methods}

\section{Study Area}

Shavers Fork is a major tributary of the Cheat River within the Ohio River basin. The Shavers Fork flows north, and its watershed (55,167 ha) comprises a part of Pocohontas, Randolph, and Tucker counties in the Eastern Allegheny Plateau of the Central Appalachian Mountains of West Virginia. The Eastern Allegheny Plateau is a primarily forested, high elevation $(\geq 900 \mathrm{~m}$ ) upland composed of sandstone, shale, conglomerate and coal (Waite et al., 2000). In particular, the Shavers Fork watershed is approximately $42 \%$ deciduous, $29 \%$ conifer, $26 \%$ mixed, $1 \%$ crop/hay pasture, $1 \%$ wetland, and 1\% low intensity human disturbance (WVDNR, 2000).

The Upper Shavers Fork watershed $\left(13,856\right.$ ha, $\left.38.5^{\circ} \mathrm{N} 79.9^{\circ} \mathrm{W}\right)$ is the southern section of the Shavers Fork (Figure 3). With exception to three kilometers of headwater stream, the Upper Shavers Fork flows entirely within the Monongahela National Forest. The mainstem lies in an elevated $(>1000 \mathrm{~m})$, low gradient basin with eastern and western confinement by Shavers and Cheat Mountains, respectively. The Upper Shavers Fork originates at nearly $1400 \mathrm{~m}$, flows north for $32 \mathrm{~km}$, and increases to fourth order. Tributaries enter at near perpendicular angles (i.e. trellised network pattern) (OSM, 1981), and their gradients are often stair-stepped with low-high-low gradient segments.

The watershed is primarily forested and, along the stream continuum, a minimum of eighty years separates prior riparian harvest (Clarkson, 1964). Remnant effects of harvest, however, include deficiencies in large ( $>15 \mathrm{~m})$ red spruce (Picea ruben) along the mainstem channel. In contrast, many headwater reaches have low gradient bogs that support naturally open canopies. A dense shrubby understory (e.g. 
Rhododenderon spp.) is generally absent, and a mixed deciduous-coniferous overstory primarily shades the stream continuum. In total, these riparian conditions provide variations in light that are not necessarily related to stream size. Headwater bogs, narrow and broad-leafed species composition, sparse shrubby understory, and downed overstory from ice and wind expose the stream to localized variations in canopy cover.

The watershed averages $122 \mathrm{~cm}$ to $152 \mathrm{~cm}$ of precipitation yearly (OSM, 1981; Clayton et al., 1998). Snow is common from November through April and thunderstorms occur about 50 days per year, mostly during June through August (WVU, 1965; OSM, 1981). Precipitation is acidic, averaging $\mathrm{pH} 4.1-4.5$, and reflects a common pattern throughout the northeastern United States (Cogbill, 1976; Carline et al., 1992; Clayton et al., 1998; Stribling et al., 1998; NADP, 2000).

Geology consists of the Pennsylvanian Pottsville Group and Mississippian Mauch Chunk Group (OSM, 1981; Clayton et al., 1998). The Pennsylvanian Pottsville Group includes sandstones, shales, and limited coal. The Mississippian Mauch Chunk Group includes sandstones, shales and limestone. Consequently, streams flowing through this latter group receive increased buffering potential. Superficial distributions of Mauch Chunk, however, are inconsistent (OSM, 1981; Gaujot, 2002) and, at best, provide short longitudinal sections of slightly buffered water with no correlation to stream size. Furthermore, when placed in the perspective of all geologic groups, the Pottsville and Mauch Chunk groups are minimally alkaline (USEPA, 1986) and provide low buffering potential for acidic input into stream waters (Reger, 1931; Galloway et al., 1976). 


\section{Site Selection}

I sampled a $25.2 \mathrm{~km}$ continuum (flow 0.01 to $2.36 \mathrm{~m}^{3} \mathrm{~s}^{-1}$ ) that incorporated a principal headwater tributary, Second Fork, and the mainstem of the Upper Shavers Fork (Figure 4). Ten sites were selected to investigate the effects of changes in basin area, canopy cover, alkalinity, and secondary parameters such as channel width and water temperature (Table 1). I was particularly interested in reach-scale variation in alkalinity and canopy cover occurring along the continuum (Figure 5). For instance, moving downstream, and thus as an overlay upon increasing stream size, selected sites had: high alkalinity and low canopy (site I), high alkalinity and high canopy (II), low alkalinity and high canopy (III, IV, and V), low alkalinity and low to high canopy (VI and VII), and high alkalinity and low canopy (VIII, IX, and X). Consequently, these sites allowed complete depiction of the relationship between spatio-temporal changes in physicochemical variables and macroinvertebrate structure and function.

\section{Field Procedures}

\section{Sampling Regime}

Benthic samples were collected from sites III $-X$ in spring (May $15^{\text {th }}-25^{\text {th }}$ ), summer (July $25^{\text {th }}-$ August $10^{\text {th }}$ ), and fall (October $\left.7^{\text {th }}-26^{\text {th }}\right) 2000$. Benthic samples for sites I and II were collected in fall (October $7^{\text {th }}-26^{\text {th }}$ ) 2000 only (see section on macroinvertebrates for explanation). I quantified microhabitat and measured $\mathrm{pH}$ immediately prior to sampling the benthos at each site each season. Additional $\mathrm{pH}$ measurements were collected whenever on site (May $15^{\text {th }} 2000$ to December $\left.5^{\text {th }} 2001\right)$. I quantified macrohabitat from May $10^{\text {th }}-25^{\text {th }} 2000$. Instream temperatures were recorded from April $1^{\text {st }}$ - October $26^{\text {th }} 2000$. I quantified percent canopy cover at each site on 
September $1^{\text {st }}-2^{\text {nd }} 2000$. Water samples for alkalinity estimates were collected on Nov. $6^{\text {th }}$ and Dec. $05^{\text {th }} 2001$.

\section{Physical Habitat}

Macrohabitat was quantified to assess the degree of change in macro-scale features with position along the stream continuum. Using Arcview 3.2, I estimated basin area, distance below headwater, and link number for each site. A link number indicates the number of $1^{\text {st }}$ order perennial streams upstream of a given site along the continuum. I used this descriptor because it represents stream size more accurately than Strahler's stream ordering system (Statzner and Higler, 1985; Childers, 2000). Channel width was measured by judging bank-full discharge (i.e. the maximum streamflow that can be incorporated within the channel without over topping the banks and spreading onto the floodplain) (Armantrout, 1998). I quantified channel width from transects spaced every one mean stream width (MSW) in the tributary (sites I-VII) and every two MSW's in the Shavers Fork mainstem (sites VIII-X). Dissimilarity between the spacing of tributary and mainstem transects was justified by the increased heterogeneity of tributary habitat versus the comparatively homogenous mainstem habitat. In addition, the increased spacing of transects in the mainstem allowed for accurate representation of the comparatively longer pool-riffle-glide habitat units. Following guidelines of Simonson et al. (1994), estimates of channel width are composites of twenty-one transects at each site.

Microhabitat was quantified to assess variation in micro-scale features among benthic sampling points. For a given sampling point, I measured bottom and average ( 0.6 total depth) current velocities with a Marsh-McBirney (model 201) electronic velocity 
meter. Substrate composition was then measured by placing a $40 \mathrm{~cm}^{2}$ viewing quadrat on the water's surface and visually estimating \% bedrock, boulder $(>256 \mathrm{~mm})$, cobble (6$256 \mathrm{~mm})$, gravel (2-64 mm), sand (1-2 mm), silt $(<1 \mathrm{~mm})$, and organic debris (Petty and Grossman, 1996). Particle classification followed a modified Wentworth scale (Minshall, 1984). Estimates of riffle microhabitat features are composites of five points from each site each season.

\section{Water Chemistry}

Alkalinity and $\mathrm{pH}$ were measured to assess the relationship between changes in water chemistry and macroinvertebrate structure and function along the stream continuum. I estimated alkalinity by sampling each site on two dates. On each date, I would triple dip and rinse 2-3 acid-bathed polyethylene bottles, then cap each below the water's surface. Samples were immediately placed in ice then titrated within $48 \mathrm{hr}$ to $\mathrm{pH}$ 4.5 using a $0.02 \mathrm{~N} \mathrm{H}_{2} \mathrm{SO}_{4}$ solution (USEPA, 1979). Estimates of alkalinity are composites of 4-6 water samples from each site.

Preceding macroinvertebrate collections, I measured $\mathrm{pH}$ with an Oakton (model 100) handheld meter. Additional measurements were collected whenever on-site (May $15^{\text {th }} 2000$ to Dec. $\left.5^{\text {th }} 2001\right)$. Estimates of $\mathrm{pH}$ are composites of 10 measurements from each site.

\section{Canopy Cover}

Canopy cover was measured to assess the relationship between changes in light and macroinvertebrate structure and function along the stream continuum. Using a 
spherical densiometer, measurements were conducted from the midstream point of transects spaced every $10 \mathrm{~m}$ immediately upstream of benthos sites. For a given point, four directional readings (i.e. upstream, downstream, left bank, right bank) were recorded from approximately $30 \mathrm{~cm}$ above the water's surface (Bain and Stevenson, 1999). Additionally at each midstream point, I visually estimated the $\%$ composition of the overstory as either deciduous or coniferous. Estimates of \% canopy cover are composites of ten points from $100 \mathrm{~m}$ of stream reach at each site.

\section{Macroinvertebrates}

Benthic samples were collected to assess the relationship among physicochemical variables and macroinvertebrate structure and function along the stream continuum. For a given sample, I hand-scoured cobble and stirred smaller substrate within a modified Hess sampler $\left(0.10 \mathrm{~m}^{2}, 250 \mu \mathrm{m}\right.$ mesh net). I preserved samples on-site with a 95\% ethanol and Rose Bengal solution (William and Williams, 1974). Estimates of macroinvertebrate communities are composites of five random samples from riffles within each site each season. I collected benthic samples from sites III-X in spring, summer, and fall 2000. However, because I was initially unaware of the presence of high

alkalinity tributaries in the headwaters of Second Fork, macroinvertebrates were collected from sites I and II in fall 2000 only.

\section{Laboratory Procedures}

Benthic samples were flushed with water and sorted into 1.0 and $0.25 \mathrm{~mm}$ sieves. All $1.0 \mathrm{~mm}$ sieve contents were separated from organic matter by dissecting microscope (Leica, model MZ6) and fully counted. I subsampled and counted $0.25 \mathrm{~mm}$ sieve contents 
by removing $100 \mathrm{ml}$ from $500 \mathrm{ml}$ of stirred, aerated water (Feminella, 1996; Angradi, 1999). Macroinvertebrates were identified to family, or genera of concern (i.e. Epeorus spp., Heptageniidae:Ephemeroptera; Eurylophella spp., Ephemerellidae:Ephemeroptera; and Parapysche spp., Hydropsychidae:Trichoptera), using Merrit and Cummins (1996), Peckarsky et al. (1990), and Wiggins (1998). Exceptions occurred for Oligocheata and Nematomorpha, which were identified to order only. Independent verifications (i.e. $<$ $10 \%$ of total collection) were performed by Janet Clayton (West Virginia Division of Natural Resources) and a verified reference collection (West Virginia University, Department of Wildlife \& Fisheries) was used for comparison. With an ocular micrometer, I measured head capsule width to the nearest $0.1 \mathrm{~mm}$ and then used regression equations (Smock, 1980; Benke et al., 1999) to convert size measurements to biomass $\left(\mathrm{mgDM} / \mathrm{m}^{2}\right)$.

\section{Statistical Analyses}

Analyses were conducted to determine whether macroinvertebrate structure and function depended more on position along the stream continuum or on site-specific changes in alkalinity and canopy cover. To measure if spatio-temporal variation in macroinvertebrate communities resulted from changes in alkalinity, canopy cover, or basin area, I performed stepwise multiple regressions, analyses of variance, coefficients of community similarity (i.e. Jaccard's coefficient), and metrics of relative and absolute abundance. In order to meet normality assumptions and reduce heteroskedasticity, I transformed density $\left(\log _{10}\right)$, biomass $\left[\log _{10}(x+1)\right]$, and percent (arcsine) data (Zar, 1996). Due to the high degree of variability inherent in macroinvertebrate distributions (Downes et al., 1993), a critical alpha ( $\alpha$ ) value of less than 0.10 was used in all multiple means 
comparison, whereas as a critical alpha $(\alpha)$ value of less than 0.15 was used in stepwise regression analyses.

Comparisons were conducted on five replicate benthic samples taken from each site each season. However, not all benthic macroinvertebrate larva and aquatic adults were included in analyses. Decapoda $(n=61)$, Oligocheata $(n=3,071)$, and Nematomorpha $(n=210)$ were removed. Such removals constituted $7 \%$ of the total macroinvertebrate community $(\mathrm{N}=47,737)$. I removed Decapoda because they can significantly increase the variance of biomass estimates (Miller, 1985). I removed Oligocheata and Nematomorpha because individuals were often in parts, and since I could not distinguish posterior and anterior regions, abundance was potentially overestimated, thereby increasing the variance of density estimates.

\section{Physical Microhabitat}

Depth $(\mathrm{m})$, bottom and average current velocities $(\mathrm{m} / \mathrm{s})$, and substrate composition $(\%)$ were measured at each benthos sampling point $\left(0.1 \mathrm{~m}^{2}\right)$. With exception to riparian debris, I expected all variables to remain consistent throughout riffles along the continuum. The amount of riparian debris should decrease as canopy cover decreases. To test for significant differences among sites along the continuum, I used one-way analysis of variance with a Tukey-Kramer Honestly Significant Difference (HSD) multiple means comparison. 


\section{Macroinvertebrate Density and Biomass}

Density and biomass were measured as the number and milligrams of dry mass per meter squared, respectively. I expected density and biomass to increase as alkalinity (e.g. Miller, 1985) and basin area increased or canopy cover decreased (e.g. Vannote et al., 1980). To test for significant differences among sites along the continuum, I used one-way analysis of variance with a Tukey-Kramer HSD multiple means comparison. Stepwise multiple regressions were then performed to rank the relative influences of alkalinity, canopy cover, and basin area on seasonal and annualized patterns in density and biomass (annualized patterns refer to the mean of a given site for spring, summer, and fall 2000).

\section{Family Richness}

Family Richness was measured as the total number of families present per site. I expected family richness to increase as alkalinity (e.g. Kimmel et al., 1985) and basin area increased or canopy cover decreased (e.g. Vannote et al., 1980). Stepwise multiple regressions were performed to rank the relative influences of alkalinity, canopy cover, and basin area on the annualized pattern in family richness.

\section{Community Similarity}

Community similarity was measured as the percent congruency (i.e. 0 - $100 \%$ ) of family-level taxa occurring among sites. I expected community similarity to decrease as the distance from a focal site increased (e.g. Vannote et al., 1980). Hence, when moving from small to large basin area sites, community similarity should progressively decrease 
(e.g. Grubaugh et al., 1996). Additionally, when moving among adjacent sites at the reach-scale, community similarity should vary with changes in alkalinity (e.g. Simpson et al., 1985) and canopy cover (e.g. Vannote et al., 1980). Thus, small-scale variability in alkalinity or canopy cover should change taxa composition and modify stream continuum predictions for community similarity at affected points along the continuum.

Jaccard Coefficients were calculated to assess the degree of similarity in community composition among sites along the continuum. This procedure has been used to determine patterns in community composition along elevation and stream size gradients (Allan, 1975; Grubaugh et al., 1996; Stribling et al., 1998). The equation is as follows:

$$
C_{j}=j /(a+b-j)
$$

where:

$\mathrm{j}=$ the number of taxa common to both samples

$\mathrm{a}=$ the number of taxa in sample $\mathrm{A}$

$\mathrm{b}=$ the number of taxa in sample B

The coefficient decreases (i.e. $C_{j}$ approaches zero) as the similarity in community composition among sites decreases. Furthermore, large decreases in the similarity coefficient, represented graphically through steep angles connecting adjacent sites, indicate an area where the rapid addition or replacement of taxa has occurred.

\section{Feeding Group Composition}

The $\%$ biomass of each feeding group was calculated from the total biomass at each site. I used Merritt and Cummins (1996) to assign a feeding group to each family, then referenced these classifications with published results from previous studies in the region (Miller, 1985; Kobuszewski and Perry, 1993; Stribling et al., 1998). The function 
established for local genera was used as decisive criteria to categorize family-level feeding guilds. Following predictions of the RCC (Vannote et al., 1980), I expected highly predictable changes in the $\%$ biomass composition of feeding groups with movement from small to large basin area sites. Specifically, I expected a shift from the dominance of $\%$ shredder and gatherer feeding groups to the dominance of $\%$ scraper and filterer feeding groups. In comparison, I expected \% predator biomass to remain consistent along the continuum (Vannote et al., 1980). Stepwise multiple regressions were performed to rank the relative influences of alkalinity, canopy cover, and basin area on the seasonal and annualized patterns in \% biomass of individual feeding groups.

Second, the $\%$ biomass of each family within a feeding group was calculated at each site. I expected the contribution of a given family to vary spatially according to alkalinity (Rosemond et al., 1992), canopy cover, and basin area (Vannote et al., 1980). I additionally expected the contribution of each family to vary seasonally (Georgian and Wallace, 1983). These family level calculations are descriptive and provide a measure of the relative biomass contribution to the absolute biomass of each feeding group. Tests of statistical significance were not performed.

Third, the seasonal and annualized mean biomass $\left(\mathrm{mgDM} / \mathrm{m}^{2}\right)$ of each feeding group was calculated from the total biomass at each site. I expected all feeding groups to have greater biomass as alkalinity increased (e.g. Miller, 1985). Similarly, I expected all feeding groups to have greater biomass as light increased (e.g. Hawkins et al., 1982). Stepwise multiple regressions were performed to rank the relative influences of alkalinity, canopy cover, and basin area on the seasonal and annualized patterns in absolute biomass of individual feeding groups. 


\section{Community Metrics}

The relative abundance of particular orders, families, and genera were measured at each site. In low alkalinity sites, I expected abundances of the comparatively acidtolerant Plecoptera to increase, while abundances of the comparatively acid-intolerant Ephemeroptera and Trichoptera decrease (e.g. Simpson et al., 1985; Allard and Moreau, 1987). Abundances of the acid-intolerant Leptophlebiidae (Ephemeroptera) should also decrease in low alkalinity sites (e.g. Rosemond et al., 1992;). In contrast, I expected an increased abundance of the acid-tolerant genera Epeorus, Eurylophella, Parapsyche within their respective families (e.g. Kobuszewski and Perry, 1993; Clayton and Menendez, 1998).

Community metrics should change again as basin area increases and canopy cover decreases (e.g. Vannote et al., 1980). Specifically, Ephemeroptera and Trichoptera should increase due to an increase in scraper, gatherer and filterer taxa with increasing stream size. Similarly, the abundance of Leptophlebiid gatherers should increase within Ephemeroptera. The genera Epeorus, Eurylophella, Parapsyche should decrease in relative abundance as additional genera in each respective family increase in abundance. These community metrics are descriptive and provide a measure of relative and absolute abundance. Tests of statistical significance were not performed.

\section{Results}

Benthic samples from ten sites over three seasons contained macroinvertebrates from fifty families and eight orders (Appendix I). Chironomidae (Diptera) comprised $49 \%$ of all individuals $(\mathrm{N}=43,395)$. Excluding Chironomidae, the orders Ephemeroptera 
(40\%), Plecoptera (36\%), Diptera (12\%), and Trichoptera (10\%) were numerically dominant, comprising $98 \%$ of all non-chironomidae taxa.

\section{Physical Microhabitat}

No significant differences occurred among sites along the continuum in mean depth, average or bottom current velocity, and \% bedrock, boulder, cobble, gravel, or sand. In fall, silt and debris significantly differed in sites II and III, respectively. Site II had increased riparian litter $(P<0.01, \mathrm{~F}=6.38, \mathrm{DF}=49)$ and site III had increased silt $(P$ $<0.01, \mathrm{~F}=15.25, \mathrm{DF}=49$ ). Mean values among sites in all three seasons were: depth 0.2 $\pm 0 \mathrm{~m}$; average current velocity $0.28 \pm 0 \mathrm{~m} / \mathrm{s}$; bottom current velocity $0.14 \pm 0 \mathrm{~m} / \mathrm{s}$; bedrock $0 \%$; boulder $1 \pm 0 \%$; cobble $44 \pm 3 \%$; gravel $29 \pm 2 \%$; sand $20 \pm 2 \%$; silt $4 \pm$ $1 \%$; and debris $2 \pm 0 \%$.

\section{Macroinvertebrate Density and Biomass}

I detected significant differences in mean macroinvertebrate density (Figure 6) and biomass (Figure 7) among sites in all three seasons of the study. These seasonal patterns are summarized by the annualized mean density and biomass for each site (except for sites I and II which represent fall 2000 only) (Figure 8). The essential patterns were as follows: (1) macroinvertebrate density and biomass tended to be lower in the middle reaches of the tributary (sites III-V); whereas (2) macroinvertebrate density and biomass tended to be higher in the upper reaches of the tributary (I and II) and the Shavers Fork mainstem (VIII and IX). An exception to this pattern was the significantly lower annualized density observed in site $\mathrm{X}$ (Figure 8). Comparison of these spatiotemporal patterns with estimates of alkalinity and canopy cover for each site indicated a 
strong influence of physico-chemical variables upon benthic macroinvertebrate density and biomass (Figure 5). Multiple regression analyses provided further evidence for such influences (Table 2). Alkalinity was the only significant predictive variable throughout every season; hence, it explained $67 \%$ of the spatial variation in annualized density. Alkalinity primarily affected biomass distributions as well. Yet, canopy cover and basin area also affected biomass, thus all three variables explained $88 \%$ of the spatial variation in annualized biomass (Table 2).

\section{Family Richness}

Macroinvertebrate family richness increased dramatically in downstream reaches, particularly with passage from the tributary into the Shavers Fork mainstem (Figure 9). Across seasons, diversity ranged from 17 families in the most upstream acidic site in Second Fork (site III in summer) to 32 families in the downstream reaches of the Shavers Fork mainstem (site $\mathrm{X}$ in spring, and site IX in fall). The variability in family richness resulted from changes in alkalinity and basin area (Table 3). Basin area explained 92\% and $72 \%$ of the spatial variation in family richness during the spring and summer seasons, respectively. Alkalinity explained $78 \%$ and $63 \%$ of the spatial variation in family richness during the fall season and the annualized distribution, respectively.

\section{Community Similarity}

For brevity, the results of sites I, III, VI, VIII, and X are presented. I focus on these sites because they cover the complete range of variability in alkalinity, canopy cover, and stream size. The greatest similarity in community taxa occurred among adjacent sites (Figure 10). Thus as the distance from a given focal site increased, steady 
reductions were observed in community similarity. Indeed, basin area was the primary determinant of community similarity along the stream continuum as sites I, III, VI, VIII, and $\mathrm{X}$ decreased in similarity when compared to sites of increasing distance. Taxa composition in site I, for example, was more similar to sites II and VI than to sites XII $\mathrm{X}$, despite the similarity of sites I and VIII - X in alkalinity and canopy cover.

I also observed an interactive effect of alkalinity and canopy cover on community similarity. In particular, a large replacement and addition of taxa occurred when moving from the lower tributary to the Shavers Fork mainstem (site VIII) (Figure 10). Between sites VII and VIII, alkalinity and canopy cover varied greatly, while basin area did not. Such change in alkalinity, canopy cover, and channel width reduced the similarity of the communities despite a relatively small change in basin area. In fact, site VIII was more similar to sites IX and X than it was to site VII, even though basin area increased by several thousand hectares (sites VIII and X) (Figure 10).

\section{Feeding Group Composition}

Alkalinity, canopy cover, and basin area significantly influenced the spatial variation in \% biomass of feeding group composition (Table 4). However, alkalinity and canopy cover better explained the seasonal spatial variation in $\%$ biomass of feeding group composition than did basin area. Specifically, alkalinity explained: (1) $78 \%$ of the spatial variation in \% gatherer biomass in spring; (2) 59\% of the spatial variation in $\%$ shredder biomass in summer; and (3) $45 \%$ of the spatial variation in $\%$ predator biomass in summer. Canopy cover explained: (1) $10 \%$ of the spatial variation in $\%$ gatherer biomass in spring; (2) $83 \%$ of the spatial variation in \% filterer biomass in summer; and (3) $29 \%$ of the spatial variation in $\%$ shredder biomass in fall. In contrast, basin area 
explained $54 \%$ of the spatial variation in $\%$ shredder biomass in spring. Yet as these findings suggest, no consistent relationship occurred between the \% biomass of any feeding group and predictive variable.

The annualized distribution of $\%$ feeding group biomass further supported these seasonal results (Table 4). Basin area did not significantly explain variation in the annualized $\%$ biomass of any feeding group. However, canopy cover and alkalinity explained $63 \%$ and $26 \%$ of the annualized spatial variation in $\%$ shredder and scraper biomass, respectively.

The contribution of an individual family to feeding group biomass varied spatially and temporally (Table 5). For example, Corydalidae (Megaloptera) contributed to predator biomass only in sites VIII - X, and in site VI, Heptageniidae (Ephemeroptera) substantially contributed to scraper biomass in spring and fall, but not in summer. Therefore, a very general summary of the top biomass contributors is as follows: Leuctridae (Plecoptera) contributed the greatest biomass to the shredder group; Heptageniidae contributed the greatest biomass to the scraper group; Chironomidae (Diptera) contributed the greatest biomass to the gatherer group; Polycentropodidae and Hydropsychidae (Trichoptera) contributed the greatest biomass to the filterer group; and Chloroperlidae and Perlodidae (Plecoptera) contributed the greatest biomass to the predator group. Appendix II contains a full account of the \% biomass, total biomass, abundance, and richness of taxa comprising feeding groups in each site each season.

Alkalinity, canopy cover, and basin area significantly influenced the spatial variation in absolute biomass of feeding group composition (Table 6). However, alkalinity and canopy cover better explained the seasonal spatial variation in absolute 
biomass of feeding group composition than did basin area. Specifically, alkalinity explained: (1) $95 \%$ and $45 \%$ of the spatial variation in gatherer and filterer biomass in spring, respectively; (2) $37 \%, 48 \%, 79 \%$, and $80 \%$ of the spatial variation in scraper, gatherer, filterer, and predator biomass in summer, respectively; and (3) $56 \%$ and $51 \%$ of the spatial variation in gatherer and filterer biomass in fall, respectively. Canopy cover explained: (1) $34 \%$ and $42 \%$ of the spatial variation in scraper and predator biomass in spring, respectively; and (2) $40 \%$ and $62 \%$ of the spatial variation in scraper and predator biomass in fall, respectively. In contrast, basin area explained $25 \%$ of the spatial variation in gatherer biomass in summer.

The annualized distribution of absolute feeding group biomass supported seasonal results for canopy cover, but not for alkalinity (Table 6). Indeed, basin area was more important than alkalinity in explaining the spatio-temporal variation in annualized biomass of all feeding groups. Basin area explained 32\%, 41\%, 29\%, 71\% and $78 \%$ of the annualized variation in shredder, scraper, gatherer, filterer, and predator biomass, respectively. Canopy cover explained $54 \%, 58 \%, 22 \%$, and $17 \%$ of the annualized variation in scraper, gatherer, filterer, and predator biomass, respectively. Alkalinity was not retained in any annualized model explaining the spatio-temporal variation in absolute biomass of feeding groups. Yet as these findings suggest, basin area and canopy cover consistently predicted the annualized absolute biomass of all feeding groups.

\section{Community Metrics}

In low alkalinity sites (III - VII), absolute abundances of Ephemeroptera and Trichoptera (Figure 11), Leptophlebiidae (Figure 12), and Hydropsychidae (Figure 13) decreased, while the absolute abundance of Parapsyche increased (Figure 13). In 
contrast, in more alkaline sites upstream and downstream of III - VII, the absolute abundance of Ephemeroptera, Trichoptera, Leptophlebiidae, and Hydropsychidae increased while Parapsyche decreased. The absolute abundance of Eurylophella varied spatially and temporally and appeared unaffected by distributions in alkalinity (Figure 14). With exception to the fall season, the absolute abundance of Epeorus also did not appear to be affected by distributions in alkalinity (Figure 15).

The greatest change in annualized relative abundances occurred in the two least alkaline sites (sites III and IV) (Table 7). For example, Trichoptera were 12\% ( $\mathrm{N}=$ 18,867) of Ephemeroptera:Plecoptera:Trichoptera (EPT) along the stream continuum, yet just $4 \%(N=2,565)$ of EPT in sites III and IV. Such decline increased the relative abundance of Plecoptera from $42 \%(\mathrm{~N}=18,867)$ of EPT along the stream continuum to $87 \%(\mathrm{~N}=2,565)$ of EPT in sites III and IV.

Upstream from these sites, alkalinity increased, canopy cover and basin area decreased, and relative abundances changed (Table 7). In particular, Ephemeroptera increased to $56 \%$ of EPT, and Eurylophella and Parapsyche contributed 1\% or less to their respective family abundance. Epeorus, however, increased from $38 \%(\mathrm{~N}=61)$ in sites III and IV to $50 \%(\mathrm{~N}=538)$ of Heptageniidae in sites I and II.

In Shavers Fork mainstem sites (VIII - X) with high alkalinity, low canopy, and increasing stream size, Epeorus, Eurylophella and Parapsyche contributed less to their respective families (Table 7). Zero Parapsyche, for example, occurred within the family Hydropsychidae $(\mathrm{N}=535)$. In contrast, the relative abundances of Leptophlebiidae, Ephemeroptera, and Trichoptera increased. The relative abundance of Plecoptera to EPT decreased in comparison to sites III and IV, and in turn, was nearly identical to sites I and 
II. Indeed, the smallest two sites most closely approximated the largest three sites in all measurements of relative abundance except \% Epeorus.

\section{Discussion}

Alkalinity was the most significant determinant of benthic macroinvertebrate community structure and function along the stream continuum. Alkalinity affected density and biomass regardless of position along the continuum. Furthermore, spatial variation in alkalinity significantly explained the annualized \% biomass of shredders as well as the seasonal patterns in absolute biomass of all feeding groups but shredders. Finally, the distribution and occurrence of several orders, families, and genera were determined more by their tolerance level to acidity than by position along the continuum.

Canopy cover was the second most significant determinant of community structure and function along the stream continuum. The effect of canopy was independent of stream size, as small tributary sites with high light had significantly higher density and biomass. Furthermore, spatial variation in canopy cover significantly explained the annualized \% biomass of scrapers as well as the annualized absolute biomass of all feeding groups but shredders. Yet the effect of canopy may not be independent of alkalinity, as the one high light / low alkalinity site (site VI) had increased density and biomass but significant differences were not seasonally consistent. Nevertheless, combinations of alkalinity and canopy cover were dominant factors affecting community structure and function along the stream continuum.

Stream size influenced community structure and function least, though effects of basin area were observed. Results of community similarity indicated that stream size was independent of alkalinity and canopy cover. Specifically, the smallest site was more 
similar to other tributary sites than it was to the Shavers Fork mainstem sites, which it most closely approximated in terms of alkalinity and canopy cover. In mainstem sites, family richness was also higher than in the smallest site, suggesting that position along the continuum affected richness more strongly than alkalinity or canopy cover. In addition, the annualized absolute biomass of all feeding groups increased with increasing basin area. Thus, alkalinity, canopy cover, and stream size interacted to affect different components of macroinvertebrate structure and function. Furthermore, because results for individual components of macroinvertebrate structure and function are complex, a more detailed synthesis follows.

\section{Macroinvertebrate Density and Biomass}

In agreement with predications of Vannote et al. (1980), significant increases in macroinvertebrate density and biomass occurred downstream. These results also support Grubaugh et al. (1996) who found large increases in density and biomass with transition from small $(<1,000 \mathrm{ha})$ to middle $(>1,500 \mathrm{ha})$ sized streams. Along their continuum, however, density and biomass showed the largest increase with transition into the Little Tennessee River (> 36,000 ha) of North Carolina.

In the smallest $(<100$ ha) sites of my study, changes in alkalinity and canopy cover presumably caused an increase in density and biomass. The significantly higher density and biomass of site II likely resulted from increased alkalinity (Feldman and Connor, 1992). The further increase in density and biomass of site I likely resulted from that site being more alkaline plus a large reduction in canopy (Hawkins et al., 1982). In fact, biomass at this smallest site was significantly higher than at all other tributary sites, and only differed significantly from the largest site. Both of these small sites (I and II) 
flow through Mauch Chunk formation (Gaujot, 2002) which, in southwestern

Pennsylvania (Madarish and Kimmel, 1999) and western Virginia (Miller, 1985), was found to cause similar improvements in alkalinity and localized macroinvertebrate structure.

Relatively high macroinvertebrate density and biomass in the least alkaline site (site III) along the continuum was unanticipated since these measurements declined in pH-depressed sites of southwestern Pennsylvania (Kimmel et al., 1985), western Virginia (Feldman and Connor, 1992), north central Virginia (Miller, 1985), and western North Carolina (Rosemond et al., 1992). Unaltered or increased density and biomass, however, is reported for more acidic sites of other tributaries in the Shavers Fork (Kobuszewski and Perry, 1993) and in southwestern Pennsylvania (Madarish and Kimmel, 1999). Thus, the observed increase in density and biomass likely reflects a competition release from colonizing, marginally acid-sensitive taxa and, in turn, a dominance of acid-tolerant taxa (Hall and Ide, 1987; Clayton and Menendez, 1998). In addition, downstream sites may have had greater fluctuations in water chemistry and a less stable chemical environment for resident macroinvertebrates (Madarish and Kimmel, 1999).

Although inconsistent across seasons, the low alkalinity / high light site (site VI) had a significantly higher density and biomass in comparison to upstream tributary sites with low alkalinity and light. Thus, alkalinity may have acted as a template upon which variations in light secondarily affected macroinvertebrate density and biomass. Specifically, low alkalinity may have indirectly reduced nutrient potential (Allan, 1995), and thereby limited the response of macroinvertebrates to light (Rosemond et al., 1993). 
The most alkaline site also had an open canopy and significantly higher density and biomass every season. Here, however, concurrent changes in stream size (Minshall et al., 1983) and instream temperature (Benke and Jacobi, 1986; Hauer and Benke, 1987; Stites and Benke, 1989) likely increased macroinvertebrate density and biomass. Therefore, the effects of alkalinity and canopy cover were likely interacting with other stream continuum predictions regarding increasing channel width and temperature (Vannote et al., 1980).

Results for the largest site were unexpected since prior research has predicted (Vannote et al., 1980) and found higher density and biomass in large sites $\left(\geq 4^{\text {th }}\right.$ order) of the Ozark Plateau (Brussock and Brown, 1991) and Southern Appalachians (Grubaugh et al., 1996). Yet, the range of alkalinity in our largest site was near the USEPA (1986) minimum threshold of $20 \mathrm{mg} / \mathrm{L} \mathrm{CaCO}_{3}$, and thus acidic episodes may have occurred during large storm events. Furthermore, winter ice-scour (Naiman et al., 1987), critical summer temperatures in excess of $25^{\circ} \mathrm{C}$ (Cada et al., 1987; Peterson and Eeckhaute, 1991; Allan, 1995), epi-benthic predation from stocked populations of brown (Salmo trutta) (Bechara et al.,1993) and rainbow (Oncorhynchus mykiss) (Feltmate, et al., 1986) trout, resulting sub-optimal habitat use by benthic macroinvertebrates (Feltmate et al., 1986; McIntosh and Townsend, 1994; Forrester, 1994), and a large principal tributary (> 1,500 ha) (Bruns et al., 1984) upstream of this site may have also added to the observed significant reduction in density and biomass.

\section{Family Richness}

Family richness followed predictions of Vannote et al. (1980), as all tributary sites had reduced family numbers in comparison to Shavers Fork mainstem sites. In particular, 
the successive increase in richness of mainstem sites likely indicated a blending of heterotrophic and autotrophic conditions (Minshall et al., 1983), and these results agree well with the findings of Brussock and Brown (1991) and Grubaugh et al. (1996) who also observed peaks in richness at $3^{\text {rd }}-5^{\text {th }}$ order sites. Furthermore, the largest tributary site had more families than the adjacent site upstream that received more light but was smaller in size. These findings suggest position along the continuum significantly affected family richness.

In addition to stream size, alkalinity also affected family richness, as the two smallest sites had more families than all other tributary sites. In fact, several acidintolerant families reappeared such as Pteronarcyid and Perlodid stoneflies (Stribling et al., 1998) (Table 8). Thus, distributions of family richness indicated significant effects of alkalinity and supported findings in other tributaries of southwestern Pennsylvania (Kimmel et al., 1985) and western Virginia (Feldman and Connor, 1992). Here, however, the effect of alkalinity on family richness was secondary to the effect of basin area.

Against expectations (Vannote et al., 1980), variation in canopy cover did not significantly affect family richness along the continuum. As with macroinvertebrate density and biomass, I believe alkalinity indirectly constrained the potential increase in family richness with increasing light (Kimmel at al., 1985; Rosemond et al, 1993; Allan, 1995). Specifically, if site VI were more alkaline, it likely would have had increased family richness (Kobuszewski and Perry, 1993; Kimmel et al., 1985; Feldman and Connor, 1992). I then believe this would have produced a significant result in the regression analyses of canopy cover. Yet, this finding may also suggest that the common observation of increased family richness with decreasing canopy cover may result from 
the typical correlation between canopy cover and basin area (but see Hawkins et al., 1982).

\section{Community Similarity}

Longitudinal changes in community taxa generally supported patterns predicted by Vannote et al. (1980). Macroinvertebrate community similarity decreased sharply with increasing distance between sites. Allan (1975) also observed communities to be more similar when less difference in elevation occurred among sites along a stream continuum in Colorado. He attributed specific areas of taxa replacement to gradual changes in the physical gradient. In comparison, the Shavers Fork has much less elevation loss along its continuum, yet localized variation in alkalinity and canopy cover produced several areas of rapid taxa replacement. For example, tributary sites I, III, and VI differed considerably from adjacent sites in all seasons. Nevertheless, localized variation in alkalinity and canopy cover was not necessarily the primary determinant of community similarity along the stream continuum. The smallest site, which is most similar in alkalinity and canopy cover to the mainstem sites, had a very dissimilar community composition from those sites. Therefore, it is likely that community similarity is influenced simultaneously by the local characteristics of alkalinity (Feldman and Connor, 1992) and canopy cover (Hawkins et al., 1982) as well as by position along the stream continuum (Allan, 1975).

Although basin area among the mainstem sites was very different, these sites were more similar to each other than they were to tributary sites. Yet a large change in community similarity occurred with transition between $3^{\text {rd }}$ order sites of the tributary and Shavers Fork mainstem. This difference occurred despite a small change in basin area. Grubaugh et al. (1996) observed a similarly large change in community taxa in two $3^{\text {rd }}$ 
order stream sites in western North Carolina. As with Allan (1975), they attributed their findings to a transition from steeply sloped mountain streams into shallow-sloped alluvial river reaches, since this represented a transitional point between two geomorphic conditions and an overlap of ecotones between the habitat tolerances of many taxa (Statzner and Higler, 1986). The transition from tributary to Shavers Fork mainstem, however, is low gradient $(<2 \%)$ and thus it is likely that the observed changes in community similarity resulted from differences in alkalinity and canopy cover, more so than from geomorphic processes dictated by position along the continuum. Furthermore, in eastern deciduous-coniferous forests the onset of autotrophy depends upon the degree of shading (Minshall 1978), which likely occurs at the $3^{\text {rd }}$ stream order (Vannote et al., 1980).

\section{Feeding Group Composition}

Against predictions of Vannote et al. (1980), stream size did not explain the spatial variation in annualized \% biomass of feeding group composition. Rather, alkalinity and canopy cover explained the spatial variation in annualized $\%$ biomass of shredders and scrapers, respectively. Direct comparison of these results with prior findings is difficult, as several studies have used benthic abundance and density to measure feeding group composition (e.g. Hawkins and Sedell, 1981; Hawkins et al., 1982; Cushing et al., 1983; Minshall et al., 1983; Rosemond et al., 1992; Kobuszewski and Perry, 1993; Madarish and Kimmel, 1999). Others have used annual macroinvertebrate production $\left(\mathrm{gDM} / \mathrm{m}^{2} / \mathrm{yr}\right)$ to compare feeding group composition (e.g. Smock et al., 1985; Huryn and Wallace, 1987). Estimates of feeding composition based on abundance, density, biomass, or production can differ significantly (Miller, 1985; 
Lugthart and Wallace, 1992; Grubaugh et al., 1996). For instance, the \% composition of shredders may be overestimated by density, predators underestimated by density, grazers and collectors more prominent than predators as production, yet less prominent than predators as biomass (Miller, 1985). Furthermore, no studies to my knowledge have investigated the $\%$ biomass of feeding groups along large (50 - 10,000 ha) stream continua having localized variation in alkalinity and canopy cover. Miller (1985), for example, conducted a comprehensive study of macroinvertebrate feeding groups including annual monthly samples that calculated density, biomass, and production estimates, yet all five sites along the stream continuum were $\leq 2^{\text {nd }}$ order $(<1900 \mathrm{ha})$. A $\mathrm{pH}$ gradient did exist, however, and his finding that less grazer taxa attained $2.0 \mathrm{mgDM}$ $/ \mathrm{m}^{2}$ in smaller sites of lower $\mathrm{pH}$ was not supported. Yet his comparisons were for $1^{\text {st }}$ to $2^{\text {nd }}$ order sites, while in this study, a comparable $\mathrm{pH}$ gradient existed only for $2^{\text {nd }}$ to $3^{\text {rd }}$ order sites. This study does support Miller's (1985) finding that Leuctrid stoneflies accounted for the largest $\%$ of shredder biomass across most sites, and that when Pteronarcyid stoneflies were present Leuctrid stonefly biomass was notably reduced (see Appendix II: site $\mathrm{X}$ in summer, and sites II, IX, and $\mathrm{X}$ in fall).

The ability of alkalinity to predict distributions in \% shredder biomass may suggest that shredders are high in headwater sites not simply because of allochthonous litter but rather: (1) headwater reaches in Central Appalachia are often acidic (Kimmel et al., 1985; Miller, 1985; Menedez et al., 1996; Madarish and Kimmel, 1999), and thus the absolute biomass of all acid-intolerant taxa are reduced regardless of feeding group; and (2) high canopy cover further decreases the absolute biomass of taxa in feeding groups 
other than shredders. Consequently, the majority of remaining taxa are acid-tolerant Plecopteran shredders (e.g. Leuctridae) (Simpson et al., 1985; Miller, 1985).

The annualized absolute biomass of feeding groups provided support for the notion that localized variation in light indiscriminately affects all feeding groups. With exception to shredders, canopy cover significantly influenced the annualized absolute biomass of all feeding groups. Although based upon macroinvertebrate abundance, Hawkins et al. (1982) observed similar results regarding the effects of light on feeding groups in open canopy stream sections of Oregon. Streams without shading had higher abundances of macroinvertebrates than did shaded streams. Specifically, open stream sites had higher abundances in the gatherer, filterer, and predator groups, while shredder abundance did not differ among shaded and open canopy stream sites (Hawkins et al., 1982).

The finding that basin area significantly influenced the annualized absolute biomass of all feeding groups may explain the lack of support for RCC predictions regarding $\%$ biomass composition of feeding groups. In particular, the absolute biomass of all feeding groups was indiscriminately influenced by stream size. Thus the \% biomass composition of feeding groups did not change in support of RCC predictions.

\section{Community Metrics}

Longitudinal changes in the relative and absolute abundances of selected orders, families, and genera indicated that the effects of alkalinity, canopy cover, and stream size interacted along the continuum. Yet, alkalinity was the primary determinant of taxa abundance. Ephemeroptera were greater than $50 \%$ of EPT in sites with alkalinity near or above the USEPA (1986) minimal standard of $20 \mathrm{mg} / \mathrm{L} \mathrm{CaCO}_{3}$, and the transition from 
Ephemeroptera to Plecoptera dominated communites is a well documented finding for benthic community structure in acidified sites (Kimmel et al., 1985; Miller, 1985; Simpson et al., 1985; Allard and Moreau, 1987; Hall and Ide; 1987; Peterson and Eeckhaute, 1991; Feldman and Connor, 1992; Rosemond et al., 1992; Clayton and Menendez, 1998; Madarish and Kimmel, 1999). Similarly, distributions of Trichoptera abundance further supported the ability of the EPT metric to depict alterations in water chemistry (Rosemond et al., 1992; Kobuszewski and Perry, 1993; Wallace et al., 1996). The increase in Leptophlebiidae in upstream, more alkaline sites supports the findings of Rosemond et al. (1992) and Clayton and Menendez (1998). The decrease in the relative abundance of Eurylophella and Parapsyche with increasing alkalinity also supports previous findings (Kobuszewski and Perry, 1993; Clayton and Menendez, 1998). In contrast, the increase in the relative and absolute abundance of Epeorus in upstream, more alkaline sites was not expected. However, species within Epeorus have differential tolerance to acidity (Feldman and Connor, 1992), and perhaps such variation was responsible for the unexpected observation.

Low canopy and increasing stream size also affected community metrics. In particular, the relative and absolute abundances of acid-sensitive taxa increased incrementally from sites III to I. Thus, the interaction of alkalinity and light were apparent upon community structure. Furthermore, these taxa were most abundant in large, highly alkaline, low canopy mainstem sites. Thus, the additional effect of increasing stream size with a wider variance in mean daily temperature was likely observed (Vannote et al., 1980). 


\section{Conclusions}

Influences on macroinvertebrate structure and function in the Upper Shavers Fork watershed are a complex interaction of factors such as water chemistry, canopy cover, and stream size. At a given point along the continuum, these factors may covary, as suggested by the RCC, and at other points they do not. When these factors do not covary, observed patterns on macroinvertebrate structure and function are quite complex and difficult to predict. Furthermore, the general idea of predictable changes along a stream continuum may be biased by the fact that water chemistry, canopy cover, and basin area can covary along a given longitudinal continuum in Central Appalachian streams. Thus, evaluation of these results suggests that small-scale variation in the geology and riparian character of Central Appalachian watersheds can modify stream continuum predictions at a continuum-specific level.

\section{Management Implications}

Stream ecosystem restoration is a scale-dependent process often requiring mitigation from outside the stream-bank such as in the riparian and surrounding watershed (Allan, 1995). Yet, the Upper Shavers Fork flows within the Monongahela National Forest and largely evades such impact. Nevertheless, problems existing within the watershed are: (1) the wet (e.g. precipitation) and dry (e.g. settling of coarse particulates and aerosols) deposition of atmospheric sulfuric and nitric acids (Clayton et al., 1998); and (2) a wide, shallow channel structure in the mainstem which decreases habitat complexity, such as the frequency of pools, and increases instream temperatures. 


\section{Headwater Tributaries}

Headwater tributaries of the Upper Shavers Fork are most affected by acid precipitation, as the confluence of buffered stream segments may not occur until further downstream. Furthermore, the influence of water chemistry on habitat suitability is significant (Angradi, 1999), as its effects on resident biota may override interrelated influences of current velocity (Mackay, 1992), depth (Huryn and Wallace, 1987), substrate (Rabeni and Minshall, 1977), and cover (Hill et al., 1995). Potential consequences of acidification include a decrease in bacterial composition (Kimmel, 1985), a resulting decrease in sediment-nutrient exchange due to organic layering, an increase in acid-tolerant fungal growth (Wright et al., 1975), and a decrease in macroinvertebrate (Kobuszewski and Perry, 1993; Clayton and Menendez, 1998) and fish structure and function (Clayton et al., 1998).

In general, macroinvertebrate communities display greater tolerances to acidification than do fish (Bell, 1971). Yet, brook trout are among the most acid-tolerant North American fish, and in comparison to cool-water species their rank increases further (Packer and Dunson, 1970). Nevertheless, in headwater tributaries of the Upper Shavers Fork brook trout productivity is likely limited by a combination of indirect (i.e. prey availability) and direct (i.e. physiology) influences. Specifically, sites affected by acidification in this study had reduced macroinvertebrate taxa richness and biomass, as well as an overrepresentation of acid-tolerant taxa. Of particular importance to fisheries management was the loss or decline of large, potentially free swimming mayflies susceptible to predation (e.g. Ameletidae, Baetidae, and Leptophlebiidae). As well, any opportunistic epi-benthic feeding of fleshy caddisflies (e.g. Philopotamidae), and large 
stoneflies (e.g. Pteronarcyidae, and Perlodidae) and dragonflies (e.g. Gomphidae) was not available. In turn, the remaining dominance of comparatively small-sized stoneflies (e.g. Leuctridae) and trueflies (e.g. Chironomidae) likely cannot provide a comparable energetic content per unit feeding effort. Furthermore, feeding may become secondarily important as acidification directly affects brook trout physiology. Effects of acidification on physiology may include: (1) excessive gill mucous production which lowers blood oxygen concentrations (Power, 1995); (2) reductions in the ability of dissolved oxygen to bind to hemoglobin (Packer and Dunson, 1970); and (3) improper cellular regulation of sodium due to excessive efflux and deficient influx from the absence of supportive oxidative processes (Wood and Mcdonald, 1982).

As a counter-treatment, the application of limestome to road-accessible headwater streams is generally inexpensive, improves water chemistry, and restores structure and function to macroinvertebrate and fish communities (Lacroix, 1992; Milner and Aston, 1995; Clayton and Menendez, 1996; Clayton and Menendez, 1998). Furthermore, the effects of liming generally last three years with streams of $\mathrm{pH} 5.0$ either attaining $\mathrm{pH} 6.0$ for more than $90 \%$ of the year (Clayton et al., 1998) or expressing an average increase of $0.4 \mathrm{pH}$ units (range 0.1-1.3 pH units) (Lacroix, 1992). Biological responses should include: (1) an increase in macroinvertebrate taxa richness (Clayton and Menendez 1996; Milner and Aston, 1995), and evenness (Clayton and Menendez, 1998); and (2) an increase in fish species richness, biomass (Clayton et al., 1998), growth, survivorship, and density (Lacroix, 1992). Thus, headwater limestone additions will likely reduce indirect and direct limitations on brook trout productivity as prey availability increases and physiology improves. Furthermore, vital ecological links should be restored as 
trophic-level interactions are renewed and habitat suitability is improved throughout the longitudinal gradient.

\section{Mainstem Channel}

Limitations on brook trout productivity in the mainstem channel of the Upper Shavers Fork likely results from the direct influences of habitat structure and instream temperature, whereas indirect influences of food availability do not appear problematic. When compared to its tributaries, deficiencies in instream structure characterize the mainstem of the Upper Shavers Fork. In general, the wide, shallow low-gradient character of the mainstem channel likely decreases structural density, depth and flow (Lyons, 1992), while simultaneously increasing water temperature. In addition, heavy riparian logging and instream boulder removal into the 1920's (Clarkson, 1964) further reduced instream structure and cover by limiting the addition of large woody debris and boulder frequency. Resulting effects on brook trout likely include: (1) increased energetic demands while feeding without the use of velocity shelters (Everest and Chapman, 1972; Fausch and White, 1981; Hayers and Jowett, 1994); (2) a reduction in pool area, frequency, and use (Beechie and Sibley, 1997); and (3) an increased metabolism (Elliot, 1976; Cada et al., 1987) from insteam temperatures that readily exceed $20^{\circ}$ Celsius, and may even exceed $25^{\circ}$ Celsius, throughout summer (Petty et al., unpublished data).

To improve physical habitat structure and thereby reduce direct limitations on brook trout productivity in the Shavers Fork mainstem, sections (i.e. $\leq 0.5 \mathrm{~km}$ ) of stream channel could be restructured and the adjacent riparian replanted with red spruce (Picea ruben). By confining the steam channel and increasing boulder frequency, trout will 
receive the direct benefits of increased depth, flow, and cover. Furthermore, by replanting the adjacent riparian, future (i.e. 50-100 years) additions of large woody debris should increase pool area, particulate organic matter and sediment retention, juvenile trout survival, and overall fish community diversity (Beechie and Sibley, 1997). As well, both management scenarios will likely reduce critically high summer temperatures. 


\section{Literature Cited}

Allan, J.D. 1975. The distribution ecology and diversity of benthic insects in Cement Creek, Colorado. Ecology 56:1040-1053.

Allan, J.D. 1995. Stream ecology: structure and function of running waters. Kluwer Academic Publishers, Norwell, MA.

Allan, J.W. and T. M. Burton. 1986. Size-dependent sensitivity of three species species of stream invertebrates to $\mathrm{pH}$ depression. In B.G. Isom, S.D. Dennis, and J.M. Bates (eds.), Impact of acid rain and deposition on aquatic biological systems. ASTM STP 928, Phillapdeplphia, PA.:54-66.

Allard, M. and G. Moreau. 1987. Effects of experimental acidification on a lotic macroinvertebrate community. Hydrobiologia 144: 37-50.

Angradi, T. R. 1999. Fine sediment and maroinvertebrate assemblages in Appalachian streams: a field experiment with biomonitoring implications. Journal North American Benthological Society 18(1):49-66.

Armantrout, N.B., compiler. 1998. Glossary of aquatic habitat inventory terminology. American Fisheries Society, Bethesda, Maryland.

Bain, M.B., and N.J. Stevenson, editors. 1999. Aquatic habitat assessment: common methods. American Fisheries Society, Bethesda, Maryland.

Baker, E.A., and T.G. Coon. 1997. Development and evaluation of alternative habitat suitability criteria for brook trout. Transactions of the American Fisheries Society 126:65-76.

Bechara, J.A., G. Moreau, and L. Hare. 1993. The impact of brook trout (Salvelinus fontinalis) on an experimental stream benthic community: the role of spatial and size refugia. Journal of Animal Ecology 62:451-464.

Beechie, T.J., and T.H. Sibley. 1997. Relationships between channel characteristics, woody debris, and fish habitat in northwestern Washington streams. Transactions of the American Fisheries Society 126:217-229.

Bell, H.L. 1971. Effects of low $\mathrm{pH}$ on the survival and emergence of aquatic insects. Water Resources 5:313-319.

Benke, A.C., and D.J. Jacobi 1986. Growth rates of mayflies in a subtropical river and their implications for secondary production. Journal of North American Benthological Society 5:107-114. 
Benke, A. C., A.D. Huryn, L. A. Smock, and J. B. Wallace. 1999. Length-mass relationships for freshwater macroinvertebrates in North America with particular reference to the southeastern United States. Journal of North American Benthological Society 18(3):308-343.

Bruns, D.A., G.W. Minshall, C.E. Cushing, K.W. Cummins, J.T. Brock, and R.L. Vannote. 1984. Tributaries as modifiers of the river continuum concept: analysis by polar ordination and regression models. Archivfur Hydrobiolgie 99(2): 208220.

Brussock, P.P., and A.V. Brown. 1991. Riffle-pool geomorphology disrupts longitudinal patterns of stream ecosystems. Hydrobiologia 220:109-117.

Burton, T.M., R.M. Stanford, and J.W. Allan. 1985. Acidification effects on stream biota and organic matter processing. Canadian Journal of Fisheries and Aquatic Science 42:669-675.

Cada, G.F., J.M. Loar, and M.J. Sale. 1987. Evidence of food limitation of rainbow and brown trout in southern Appalachian soft-water streams. Transactions of the American Fisheries Society 116:692-702.

Carline, R.F., D.R. Dewalle, W.E. Sharpe, B.A. Dempsey, C.J. Gagen, and B. Swistock. 1992. Water chemistry and fish community responses to episodic stream acidification in Pennsylvania. Environmental Pollution 78:45-48.

Carpenter, D.A. 2000. Testing the river continuum concept: exploring ecological processes in the Wheeling Creek watershed. Master's Thesis. West Virginia University. 80 pp. http://etd.wvu.edu//ETDS/E1879/Carpenter_Deborah_Thesis. pdf

Childers, H.M. 2000. Scale, ecological fallacy, and the river continuum concept. Master's Thesis. West Virginia University. 49 pp. http://etd.wvu.edu//ETDS/E1849/Childers_H_Thesis.pdf

Clarke, K.D. and D.A. Scruton. 1997. The benthic community of stream riffles in Newfoundland, Canada and its relationship to selected physical and chemical parameters. Journal of Freshwater Ecology 12(1):113-121.

Clarkson, R.B. 1964. Tumult on the mountains, lumbering in West Virginia, 1770-1920. $8^{\text {th }}$ edition. McClain Printing Company, Parsons, West Virginia.

Clayton, J.L., and R. Menendez. 1996. Macroinvertebrate responses to mitigative liming of Dogway Fork, West Virginia. Restoration Ecology 4:234-246. 
Clayton, J.L., E.S. Dannaway, R. Menendez, H.W. Rauch, and P.E. Zurbuch. 1998. Application of limestone to restore fish communities in acidified streams. North American Journal of Fisheries Management 18:347-360.

Clayton, J.L., and R. Menendez. 1998. Macroinvertebrate response to instream applications of fine-grained limestone to mitigate acid deposition. WVDNR Project Report to United States Fish and Wildlife Service.

Cogbill, C.V. 1976. The history and character of acid precipitation in eastern North America. Water, Air and Soil Pollution 6:407-413.

Cushing, C.E., C.D. McIntire, K.W. Cummins, G.N. Minshall, R.C. Petersen, J.R. Sedell, and R.L. Vannote. 1983. Relationships among chemical, physical, and biological indices along a river continua based on multivariate analyses. Archiv Fur Hydrobiologie 98:317-326.

Cushing, C.E. 1994. The conception and testing of the river continuum concept. Bulletin of the North American Benthological Society. 11(2):225-229.

Downes, B.J., P.S. Lake, and E.S.G. Schrieber. 1993. Spatial variation in the distribution of stream invertebrates: implication of patchiness for models of community organization. Freshwater Biology 30:119-132.

Egglishaw, H.J. 1968. The quantitative relationship between bottom fauna and plant detritus in streams of different calcium concentrations. Journal of Applied Ecology 5:731-740.

Elliot, J.M. 1976. The energetics of feeding, metabolism, and growth of the brown trout (Salmo trutta L.) in relation to body weight, water temperature, and ration size. Journal of Animal Ecology 45:923-948.

Everest, F.H., and D.H. Chapman. 1972. Habitat selection and spatial interaction by juvenile chinook salmon and steelhead trout in two Idaho streams. Journal of the Fisheries Research Board of Canada 29:91-100.

Facey, D.E., and G.D. Grossman. 1992. The relationship between water velocity, energetic costs, and microhabitat use on four North American stream fishes. Hydrobiologia 239:1-6.

Fausch, K.D. 1984. Profitable stream positions for salmonids: relating specific growth rate to net energy gain. Canadian Journal of Zoology 62:441-451.

Fausch, K.D., and R.J. White. 1981. Competition between brook trout (Salvelinus fontinalus) and brown trout (Salmo trutta) for positions in a Michigan stream. Canadian Journal of Fisheries and Aquatic Sciences 38:1220-1227. 
Feldman, R.S., and E.F. Connor. 1992. The relationship between $\mathrm{pH}$ and community structure of invertebrates in streams of the Shenandoah National Park, Virginia, U.S.A. Freshwater Biology 27:261-276.

Feltmate, B.W., R.L. Baker, and P.J. Pointing. 1986. Distribution of the stonefly nymph Paragnetina media (Plecoptera: Perlidae): influence of prey, predators, current speed, and substrate composition. Canadian Journal of Fisheries and Aquatic Sciences 43:1582-1587.

Feminella, J.W. 1996. Comparison of benthic macroinvertebrate assemblages in small streams along a gradient of flow permanence. Journal North American Benthological Society 15(4):651-659.

Fiss, F.C., and R.F. Carline. 1993. Survival of brook trout embryos in three episodically acidified streams. Transactions of the American Fisheries Society 122:268-278.

Forrester, G.E. 1994. Influences of predatory fish on the drift dispersal and local density of stream insects. Ecology 75(5):1208-1218.

Gagen, C.J., W.E. Sharpe, and R.F. Carline. 1993. Mortality of brook trout, mottled sculpins, and slimy sculpins during acidic episodes. Transactions of the American Fisheries Society 122:616-628.

Galloway, J.N., G.E. Likens, and E.S. Edgerton. 1976. Hydrogen ion speciation in the acid precipitation of the northeastern U.S. in Proceedings on the first international symposium on acid precipitation and the forest ecosystem. Forest Service General Technical Report. NE-23. pp. 383-396.

Garden, A. and R.W. Davies. 1989. Decomposition of leaf litter exposed to simulated acid rain in a buffered lotic system. Freshwater biology 22:33-44.

Gaujot, R.C. 2002. Geology, surface hydrology, and fish habitat relationships in the upper Shaver Fork drainage basin, West Virginia. Master's Thesis. West Virginia University. $95 \mathrm{pp}$.

Georgian, T., and J.B. Wallace. 1983. Seasonal production in a guild of periphytongrazing insects in a southern Appalachian stream. Ecology 64(5):1236-1248.

Grubaugh, J.W, J.B. Wallace, and E.S. Houston. 1996. Longitudinal changes in macroinvertebrate communities along an Appalachian stream continuum. Canadian Journal Fisheries Aquatic Sciences 53:896-909.

Groom, A.P., and A.G. Hildrew. 1989. Food quality for detritivores in streams of contrasting pH. Journal of Animal Ecology 58:863-881. 
Hall, R.J, G.E. Likens, S.B. Fiance, and G.R. Hendrey. 1980. Experimental acidification of a stream in the Hubbard Brook experimental forest, New Hampshire. Ecology 61(4):976-989.

Hall, R.J., M.J. Pratt, and G.E. Likens. 1982. Effects of experimental acidification on macroinvertebrate drift diversity in a mountain stream. Water, Soil, and Air Pollution 18:273-287.

Hall, R.J. and F.P Ide. 1987. Evidence of acidification effects on stream insect communities in central Ontario between 1937 and 1985. Canadian Journal of Fisheries and Aquatic Science 44:1652-1657.

Hall, R.J. 1990. Relative importance of seasonal, short term $\mathrm{pH}$ disturbances during discharge variation on a stream ecosystem. Canadian Journal of Fisheries and Aquatic Science 47:2261-2274.

Hauer F.R. and A.C. Benke. 1987. Influence of temperature and river hydrograph on black fly growth rates in a subtropical blackwater river. Journal of North American Benthological Society. 6:251-261.

Havas, M. 1981. Physiological response of aquatic animals to low pH. In R. Singer (ed.), Effects of acid precipitation on benthos. Proceedings of a regional symposium on benthic biology. North American Benthological Society, Springfiled, IL.:49-65.

Hawkins, C.P., and J.R. Sedell. 1981. Longitudinal and seasonal changes in functional organization of macroinvertebrate communities in four Oregon streams. Ecology 62(2):387-397.

Hawkins, C.P., M.L. Murphy, N.H. Anderson. 1982. Effects of canopy, substrate composition, and gradient on the structure of macroinvertebrate communities in Cascade Range streams of Oregon. Ecology 63:1840-1856.

Hayes, J.W., and I.G. Jowett. 1994. Microhabitat models of large drift feeding brown trout in three New Zealand streams. North American Journal of Fisheries Management 14:710-725.

Hermann, J. and K.G. Andersson. 1986. Aluminum impact on respiration of lotic mayflies at low pH. Water, Air, and Soil Pollution. 30:703-709.

Hill, J., and G.D. Grossman. 1993. An energetic model of microhabitat use for rainbow trout and rosyside dace. Ecology 74(3):685-698.

Hill, W.R., M.G. Ryon, and E.M. Schilling. 1995. Light limitation in a stream ecosystem: responses by primary producers and consumers. Ecology 76(4):1297-1309. 
Hopkins, P.S., K.W. Kratz, and S.D. Cooper. 1989. Effects of experimental pulse on invertebrates in a high altitude Sierra Nevada stream. Hydrobiologia 171:45-58.

Hughes, N.F., and L.M. Dill. 1990. Position choice by drift-feeding salmonids: model and test for arctic grayling (Thymallus arcticus) in subarctic mountain streams, interior Alaska. Canadian Journal of Fisheries and Aquatic Sciences 47:20392048.

Hughes, N.F. 1998. A model of habitat selection by drift-feeding stream salmonids at different scales. Ecology 79(1):281-294.

Huryn, A.D. and J.B. Wallace. 1987. Local geomorphology as a determinant of macrofaunal production in a mountain stream. Ecology 68(6):1932-1942.

Kimmel, W.G., and D.J. Murphey, W.E. Sharpe, and D.R. Dewalle. 1985. Macroinvertebrate community structure and detritus processing rates in two southwestern Pennsylvanian streams acidified by atmospheric deposition. Hydrobiologia 124:97-102.

Kiffney, P.M., and W.H. Clements. 1996. Effects of metals on stream macroinvertebrate assemblages from different altitudes. Ecological Applications 6(2):472-481.

Kobuszewski, D.M. and S.A. Perry. 1993. Aquatic insect community structure in an acidic and a circumneutral stream in the Appalachian Mountains of West Virginia. Journal Freshwater Ecology 8(1):37-45.

Kwak, T.J., and T.F. Waters. 1997. Trout production and water quality in Minnesota streams. Transactions of the American Fisheries Society 126:35-48.

Lacroix, G.L. 1989. Production of juvenile Atlantic salomon (salmo solar) in two acidic rivers in Nova Scotia. Canadian Journal of Fisheries and Aquatic Sciences 46:2003-2018.

Lacroix, G.L. 1992. Mitigation of low stream $\mathrm{pH}$ and its effects on salmonids. Environmental Pollution, 157-163. 0269-7491/92 Elseveir Science Publishers Ltd. England.

Lugthart, G.J., and J.B. Wallace. 1992. Effects of disturbance on benthic functional structure and production in mountain streams. Journal of the North American Benthological Society 11:138-164.

Lyons, J. 1992. Length of stream to sample with a towed electrofishing unit when fish species richness is estimated. North American Journal of Fisheries Management 12:198-203. 
Mackay, R.J. 1992. Colonization by lotic macroinvertebrates: a review of patterns and processes. Canadian Journal of Fisheries and Aquatic Sciences 49:617-628.

Madarish, D.M. and W.G. Kimmel. 1999. Benthic macroinvertebrate community structure in relation to seasonal and geochemical changes in a chronically acidified stream. Journal of Freshwater Ecology 14(3):13-26.

Marschall, E.A. and L.B. Crowder. 1996. Assessing population reponses to multiple anthropogenic effects: a case study with brook trout. Ecological Applications 6(1):152-167.

McIntosh, A.R., and C.R. Townsend. 1994. Interpopulation variation in mayfly antipredator tactics: differential effects of contrasting predatory fish. Ecology 75(7):2078-2090.

Meritt, R. W., and K. W. Cummins. 1996. An introduction to the aquatic insects of North America. $3^{\text {rd }}$ edition. Kendall and Hunt. Dubuque, Iowa.

Milner, A.G.P., and R.J. Aston. 1995. Pre and post liming of aquatic communities and trout diets. Chemistry and Limnology 9:193-205.

Miller, C. 1985. Correlates of habitat favourability for benthic macroinvertebrates at five stream sites in an Appalachian Mountain drainage basin, U.S.A. Freshwater Biology 15:709-733.

Minshall, G.W. 1978. Autotrophy in stream ecosystems. Bioscience 28:767-771.

Minshall G.W., R.C. Peterson, K.W. Cummins, T.L. Bott, J.R. Sedell, C.E. Cushing and R.L. Vannote. 1983. Interbiome comparison of stream ecosystem dynamics. Ecological Monographs 53(1):1-25.

Minshall, G. M. 1984. Aquatic insect - substratum relationships. In the ecology of aquatic insects. Edited by V. H. Resh and D. M. Rosenberg, Preager, New York, N.Y. pp. 358-400.

Minshall, G.W., K.W. Cummins, R.C. Petersen, C.E. Cushing, D.A. Bruns, J.R. Sedell, and R.L. Vannote. 1985. Developments in stream ecosystem theory. Canadian Journal of Fisheries and Aquatic Sciences 42:1045-1055.

Meyer, J.L., and R.T. Edwards. 1990. Ecosystem metabolism and turnover of organic carbon along a blackwater river continuum. Ecology 71(2):668-677.

NADP. 2000. http://nadp.sws.uiuc.edu. National Atmospheric and Deposition Program. 
Naiman, R.J., and J.R. Sedell. 1980. Relationships between metabolic parameters and stream order in Oregon. Canadian Journal of Fisheries and Aquatic Sciences 37:834-847.

Naiman, R.J. 1983. The annual pattern and spatial distribution of aquatic oxygen metabolism in boreal forest watersheds. Ecological Monographs 53(1):73-94.

Naiman, R.J., J.M. Melillo, M.A. Lock, and T.E. Ford. 1987. Longitudinal patterns of ecosystem processes and community structure in a sub-arctic river continuum. Ecology 68(5):1139-1156.

Nislow, K.H., C.L. Folt, and D.L. Parrish. 1999. Favorable foraging locations for young atlantic salmon: application to habitat and population restoration. Ecological Applications 9(3):1085-1099.

OSM. 1981. Shavers Fork Petition Evaluation. Office of Surface Mining. Final 522 SMCRA Evaluation. OSM-PE-3.

Packer, R.K., and W.A. Dunson. 1970. Effects of low environmental pH on blood pH and sodium balance of brook trout. Journal of Experimental Zoology 174:65-71.

Peckarsky, B.L., P.R. Faissinet, M.A. Penton, and D.J. Conklin, Jr. 1990. Freshwater macroinvertebrates of the northeastern United States. Cornell University Press. Ithica, New York.

Peterson, R.H., and L.V. Eeckhaute. 1991. Distributions of Epemeroptera, Plecoptera, and Trichoptera of three maritime catchments differing in $\mathrm{pH}$. Freshwater Biology 21:67-77.

Petty, J. T., and G. D. Grossman. 1996. Patch selection by mottled sculpin (Pisces: Cottidae) in a southern Appalachian stream. Freshwater Biology 35:261-276.

Power, G. 1995. The brook charr, Salvelinus fontinalis. in E.K. Balon editor, Charrs: salmonid fishes of the genus Salvelinus. Dr W. Junk bv Publishers. pp. 141-203.

Rabeni, C.F. and G.M. Minshall. 1977. Factors affecting the microdistribution of stream benthic insects. Oikos 29:33-43.

Reger, D.B. 1931. West Virginia Geological Survey, County Reports, Randolph County. Morgantown Printing and Binding, Morgantown, WV.

Rockwood, J.P., D.S. Jones, and R.A. Coler. 1990. The effect of aluminum in soft water at low $\mathrm{pH}$ on oxygen consumption by the dragonfly Libellula Julia. Hydrobiologia 190:55-59. 
Rosemond, A.D., P.J. Mulholland, and J.W. Elwood. 1993. Top-down and bottom-up control of stream periphyton: effects of nutrients and herbivores. Ecology 74(4):1264-1280.

Rosemond, A.D., S.R. Reice, J.W. Elwood, and P.J. Mulholland. 1992. The effects of stream acidity on benthic invertebrate communities in the south-eastern United States. Freshwater Biology 27:193-209.

Rowe, L.M., M. Berrill, L. Hollett, and R.J. Hall. 1989. The effects of short-term laboratory $\mathrm{pH}$ depressions on molting, mortality, and major ion concentrations in the mayflies Stenenoma femoratum and Leptophlebia cupida. Hydrobiologia 184:89-97.

Schell, V.A and J.J. Kerekes. 1989. Distribution, abundance and biomass of benthic macroinvertebrates relative to $\mathrm{pH}$ and nutrients in eight lakes of Nova Scotia, Canada. Water, Air and Soil Pollution 46:359-374.

Schlosser, I.J., and P.L. Angermeier. 1995. Spatial variation in demographic processes of lotic fishes: conceptual models, empirical evidence, and implication for conservation. American Fisheries Society Symposium 17:392-401.

Simonson, T.D., J. Lyons, and P.D. Kanehl. 1994. Quantifying fish habitat in streams: spacing, sample size, and a proposed framework. North American Journal of Fisheries Management 14:607-615.

Simpson, K.W., R.W. Bode, and J.R. Colquhoun. 1985. The macroinvertebrate fauna of an acid-stressed headwater stream system in the Adirondack Mountains, New York. Freshwater Biology 15:671-687.

Smock, L. A. 1980. Relationships between body size and biomass of aquatic insects. Freshwater Biology 10:375-383.

Smock, L.A., E. Gilinsky, and D.L. Stoneburner. 1985. Macroinvertebrate production in a southwestern United States blackwater stream. Ecology 66(5):1491-1503.

Soderstrom, O. 1988. Effects of temperature and food quality on life-history parameters in Parameletus chelifer and P. minor (Ephemeroptera): a laboratory study. Freshwater Biology 20:295-303.

Statzner, B., and B. Higler. 1985. Questions and comments on the river continuum concept. Canadian Journal of Fisheries and Aquatic Sciences 42:1038-1044.

Statzner, B., and B. Higler 1986. Stream hydraulics as a major determinant of benthic invertebrate zonation patterns. Freshwater Biology 16:127-139. 
Stites, D.L., and A.C. Benke. 1989. Rapid growth rates of chironomids in three habitats of a subtropical blackwater river and their implications for $P-B$ ratios.

Limnological Oceanography 34:1278-1289.

Stribling, J.B., B.K. Jessup, J.S. White, D. Boward, and M. Hurd. 1998. Development of a benthic index of biotic integrity for Maryland streams, Tetra Tech, Inc., Owings Mills, MD and Maryland Department of Natural Resources, Resource Assessment Service, Monitoring and Non-Tidal Assessment Division. CBWP-EA-98-3, NTIS No. PB99-240223.

USEPA. 1979. Methods for chemical analysis of water and wastes. 600/4-79-020. Washington, DC. U.S. Environmental Protection Agency.

USEPA. 1986. Quality criteria for water 1986. U.S. Environmental Protection Agency, Office of water regulations and standards, EPA 440/5-86-001, Washington DC.

Vannote, R.L., G.W. Minshall, K.W. Cummins, J.R. Sedell, and C.E. Cushing. 1980. The river continuum concept. The Canadian Journal of Fisheries and Aquatic Sciences 37:130-137.

Waite, I.R., A.T. Herlihy, D.P. Larsen, and D.J. Klemm. 2000. Comparing strengths of geographic and non-geographic classifications of stream benthic macroinvertebrates in the Mid-Atlantic Highlands, USA. Journal of the North American Benthological Society 19(3):429-441.

Wallace, J.B., J.W. Grubaugh, and M.R. Whiles. 1996. Biotic indices and stream ecosystem processes: results from an experimental study. Ecological Applications 6(1): 140-151.

Wiggins, G.B. 1998. Larvae of the North American caddisfly genera. $2^{\text {nd }}$ edition. University of Toronto Press. Toronto, Ontario.

Williams D.D. and Williams, N.E., 1974. A counter staining technique for use in sorting benthic samples. Limnology and Oceanography 19:152-154.

Winterbourne, M.J., J.S. Rounick, and B. Cowie. 1981. Are New Zealand stream ecosystems really different? New Zealand Marine and Freshwater Resources 15:321-328.

Wood, C.M., and D.G. Mcdonald. 1982. Physiological mechanisms of acid toxicity to fish. in R.E. Johnson editor, Acid rain / fisheries. American Fisheries Society Northeastern Division, Bethesda, Maryland. pp. 197-226.

Wright, R.F., T. Dale, E.T. Gjessing, G.R. Hendrey, A. Henriksen, M. Johannessen, and I.P. Muniz. 1975. Impact of acid precipitation on freshwater ecosystems in Norway. Water, Air, and Soil Pollution 6:483-499. 
WVDNR. 2000. http://www.dep.state.wv.us/watershed/w5020004.html. West Virginia Division of Natural Resources.

WVU. 1965. Agricultural Experiment Station, West Virginia University. Climatological Survey \#20-46-2, Morgantown, West Virginia, USA.

Zar, J.H. 1996. Biostatistical Analysis. $3^{\text {rd }}$ Edition. Prentice-Hall Inc. 
Table 1. Macroinvertebrate sampling sites and corresponding values for physical and chemical parameters along a $25.2 \mathrm{~km}$ continuum of the Upper Shavers Fork, WV, May - October 2000.

\begin{tabular}{|c|c|c|c|c|c|c|c|c|}
\hline Site & $\begin{array}{l}\text { Basin } \\
\text { Area } \\
\text { (ha) }\end{array}$ & $\begin{array}{c}\text { DBHW } \\
(\mathrm{km})\end{array}$ & $\begin{array}{c}\text { Link } \\
\text { Number }\end{array}$ & $\begin{array}{c}\text { Mean } \\
\text { Channel } \\
\text { Width (m) }\end{array}$ & $\begin{array}{c}\text { Mean } \\
\text { Canopy } \\
\text { Cover (\%) }\end{array}$ & $\begin{array}{c}\text { Deciduous/ } \\
\text { Coniferous } \\
(\%)\end{array}$ & $\begin{array}{c}\text { Mean } \\
\text { Alkalinity } \\
\text { (range) }\end{array}$ & $\begin{array}{c}\text { Mean } \\
\text { pH } \\
\text { (range) }\end{array}$ \\
\hline I & 48 & 1.2 & 01 & $3.9 \pm 0.0$ & $31 \pm 6$ & $44 / 56$ & $22.4(22.0-22.8)$ & $6.8(5.5-7.4)$ \\
\hline II & 98 & 1.9 & 02 & $5.4 \pm 0.0$ & $92 \pm 1$ & $88 / 12$ & $17.2(16.3-18.0)$ & $6.7(6.1-7.2)$ \\
\hline III & 469 & 3.0 & 03 & $7.9 \pm 2$ & $92 \pm 1$ & $78 / 22$ & $4.2(4.0-4.3)$ & $5.6(4.5-6.6)$ \\
\hline IV & 540 & 3.8 & 03 & $9.5 \pm 2$ & $92 \pm 2$ & $71 / 29$ & $7.6(7.2-8.0)$ & $6.0(4.5-6.8)$ \\
\hline $\mathrm{V}$ & 1043 & 4.8 & 07 & $9.9 \pm 2$ & $84 \pm 3$ & $92 / 08$ & $8.3(8.0-8.5)$ & $6.3(5.8-6.8)$ \\
\hline VI & 1225 & 5.5 & 09 & $9.8 \pm 2$ & $54 \pm 5$ & $69 / 31$ & $8.9(7.0-10.8)$ & $6.5(5.7-7.3)$ \\
\hline VII & 1464 & 6.6 & 11 & $11.8 \pm 3$ & $74 \pm 7$ & $54 / 36$ & $10.0(10.0-10.2)$ & $6.5(6.0-7.1)$ \\
\hline VIII & 1640 & 9.5 & 17 & $16.0 \pm 4$ & $44 \pm 5$ & $45 / 55$ & $66.7(30.0-136.0)$ & $6.9(6.4-7.4)$ \\
\hline IX & 5106 & 18.1 & 38 & $20.8 \pm 5$ & $21 \pm 4$ & $95 / 05$ & $47.0(24.0-92.0)$ & $6.8(6.6-7.1)$ \\
\hline $\mathrm{X}$ & 10300 & 26.4 & 75 & $26.9 \pm 6$ & $7 \pm 1$ & $79 / 21$ & $39.7(22.0-80.0)$ & $6.4(6.2-6.9)$ \\
\hline
\end{tabular}

DBHW $=$ Distance Below Headwater. Link Number $=$ The number of $1^{\text {st }}$ order perennial streams comprising a given site along the continuum. Mean $(n=20)$ Channel Width. Mean $(n=10)$ Canopy Cover. Mean $(n=4-6)$ Alkalinity $(\mathrm{mg} / \mathrm{L} \mathrm{CaCO}))$ Mean $(n=10) p H$. 
Table 2. Response of macroinvertebrate density and biomass to the effects of alkalinity, canopy cover, and basin area along a $25.2 \mathrm{~km}$ continuum of the Upper Shavers Fork, WV, May - October 2000.

\begin{tabular}{|c|c|c|c|c|c|c|}
\hline Season & $\begin{array}{c}\text { Response } \\
\text { Variable }\end{array}$ & $\begin{array}{l}\text { Predictor } \\
\text { Variable }\end{array}$ & DF & F-value & $\mathrm{R}^{2}$ & $P$-value \\
\hline \multirow[t]{5}{*}{ Spring } & \multirow[t]{2}{*}{ Density } & $\begin{array}{c}\text { Alkalinity } \\
\text { Canopy Cover } \\
\text { Basin Area }\end{array}$ & 7 & 25.7 & 0.81 & $\begin{array}{c}0.002 \\
\text { NS } \\
\text { NS }\end{array}$ \\
\hline & & Full Model & 7 & 25.7 & 0.81 & 0.002 \\
\hline & \multirow[t]{3}{*}{ Biomass } & Alkalinity & 7 & 17.9 & 0.75 & 0.006 \\
\hline & & Canopy Cover & & & & NS \\
\hline & & Full Model & 7 & 17.9 & 0.75 & 0.006 \\
\hline \multirow[t]{8}{*}{ Summer } & \multirow[t]{4}{*}{ Density } & Alkalinity & 7 & 8.8 & 0.60 & 0.025 \\
\hline & & Canopy Cover & & & & NS \\
\hline & & Basin Area & & & & NS \\
\hline & & Full Model & 7 & 8.8 & 0.60 & 0.025 \\
\hline & \multirow[t]{4}{*}{ Biomass } & Alkalinity & 7 & 11.1 & 0.65 & 0.016 \\
\hline & & Canopy Cover & 7 & 3.3 & 0.10 & 0.145 \\
\hline & & Basin Area & 7 & 3.0 & 0.13 & 0.145 \\
\hline & & Full Model & 7 & 9.7 & 0.88 & 0.026 \\
\hline \multirow[t]{6}{*}{ Fall } & \multirow[t]{3}{*}{ Density } & Alkalinity & 9 & 10.4 & 0.57 & 0.012 \\
\hline & & $\begin{array}{c}\text { Canopy Cover } \\
\text { Basin Area }\end{array}$ & & & & $\begin{array}{l}\text { NS } \\
\text { NS }\end{array}$ \\
\hline & & Full Model & 9 & 10.4 & 0.57 & 0.012 \\
\hline & \multirow[t]{3}{*}{ Biomass } & Alkalinity & 9 & 16.8 & 0.68 & 0.003 \\
\hline & & Canopy Cover & 9 & 2.7 & 0.0900 & 0.144 \\
\hline & & Full Model & 9 & 11.6 & 0.77 & 0.006 \\
\hline \multirow[t]{8}{*}{ Annual } & \multirow[t]{4}{*}{ Density } & Alkalinity & 9 & 16.2 & 0.67 & 0.004 \\
\hline & & Canopy Cover & & & & NS \\
\hline & & Basin Area & & & & NS \\
\hline & & Full Model & 9 & 16.2 & 0.67 & 0.004 \\
\hline & \multirow[t]{4}{*}{ Biomass } & Alkalinity & 9 & 13.6 & 0.63 & 0.006 \\
\hline & & Canopy Cover & 9 & 4.9 & 0.10 & 0.069 \\
\hline & & Basin Area & 9 & 6.9 & 0.14 & 0.074 \\
\hline & & Full Model & 9 & 13.9 & 0.88 & 0.004 \\
\hline
\end{tabular}

$\mathrm{NS}=$ no significance in model $(P>0.15)$. 
Table 3. Response of macroinvertebrate family richness to the effects of alkalinity, canopy cover, and basin area along a $25.2 \mathrm{~km}$ continuum of the Upper Shavers Fork, WV, May - October 2000.

\begin{tabular}{|c|c|c|c|c|c|c|}
\hline Season & $\begin{array}{l}\text { Response } \\
\text { Variable }\end{array}$ & $\begin{array}{l}\text { Predictor } \\
\text { Variable }\end{array}$ & DF & F-value & $\mathrm{R}^{2}$ & $P$-value \\
\hline \multirow{4}{*}{ Spring } & Richness & Alkalinity & & & & NS \\
\hline & & Canopy Cover & & & & NS \\
\hline & & Basin Area & 7 & 72.3 & 0.92 & $<0.001$ \\
\hline & & Full Model & 7 & 72.3 & 0.92 & $<0.001$ \\
\hline \multirow[t]{4}{*}{ Summer } & Richness & Alkalinity & & & & NS \\
\hline & & Canopy Cover & & & & NS \\
\hline & & Basin Area & 7 & 15.2 & 0.72 & 0.008 \\
\hline & & Full Model & 7 & 15.2 & 0.72 & 0.008 \\
\hline \multirow[t]{4}{*}{ Fall } & Richness & Alkalinity & 9 & 29.0 & 0.78 & 0.001 \\
\hline & & Canopy Cover & & & & NS \\
\hline & & Basin Area & & & & NS \\
\hline & & Full Model & 9 & 29.0 & 0.78 & 0.001 \\
\hline \multirow[t]{4}{*}{ Annual } & Richness & Alkalinity & 9 & 13.5 & 0.63 & 0.006 \\
\hline & & Canopy Cover & & & & NS \\
\hline & & Basin Area & & & & NS \\
\hline & & Full Model & 9 & 13.5 & 0.63 & 0.006 \\
\hline
\end{tabular}

$\mathrm{NS}=$ no significance in model $(P>0.15)$ 
Table 4. Response of percent biomass of feeding groups to the effects of alkalinity, canopy cover, and basin area along a $25.2 \mathrm{~km}$ continuum of the Upper Shavers Fork, WV, May - October 2000.

\begin{tabular}{|c|c|c|c|c|c|c|}
\hline Season & $\begin{array}{l}\text { Response } \\
\text { Variable }\end{array}$ & $\begin{array}{l}\text { Predictor } \\
\text { Variable }\end{array}$ & DF & F-value & $\mathrm{R}^{2}$ & $P$-value \\
\hline \multirow[t]{4}{*}{ Spring } & \% Shredder & Alkalinity & & & & NS \\
\hline & & Canopy Cover & & & & NS \\
\hline & & Basin Area & 7 & 7.2 & 0.54 & 0.037 \\
\hline & & Full Model & 7 & 7.2 & 0.54 & 0.037 \\
\hline \multirow[t]{4}{*}{ Summer } & & Alkalinity & 7 & 8.5 & 0.59 & 0.027 \\
\hline & & Canopy Cover & & & & NS \\
\hline & & Basin Area & & & & NS \\
\hline & & Full Model & 7 & 8.5 & 0.59 & 0.027 \\
\hline \multirow[t]{3}{*}{ Fall } & & Alkalinity & & & & NS \\
\hline & & Canopy Cover & 9 & 3.2 & 0.29 & 0.111 \\
\hline & & $\begin{array}{l}\text { Basin Area } \\
\text { Full Model }\end{array}$ & 9 & 3.2 & 0.29 & $\begin{array}{l}\text { NS } \\
0.111\end{array}$ \\
\hline \multirow[t]{3}{*}{ Annual } & & Alkalinity & & & & NS \\
\hline & & Canopy Cover & 9 & 13.8 & 0.63 & 0.006 \\
\hline & & Full Model & 9 & 13.8 & 0.63 & 0.006 \\
\hline \multirow[t]{4}{*}{ Spring } & $\%$ Scraper & Alkalinity & & & & NS \\
\hline & & Canopy Cover & & & & NS \\
\hline & & Basin Area & & & & NS \\
\hline & & Full Model & & & & NS \\
\hline \multirow[t]{4}{*}{ Summer } & & Alkalinity & & & & NS \\
\hline & & Canopy Cover & & & & NS \\
\hline & & Basin Area & & & & NS \\
\hline & & Full Model & & & & NS \\
\hline \multirow[t]{4}{*}{ Fall } & & Alkalinity & & & & NS \\
\hline & & Canopy Cover & & & & NS \\
\hline & & Basin Area & & & & NS \\
\hline & & Full Model & & & & NS \\
\hline \multirow[t]{4}{*}{ Annual } & & Alkalinity & 9 & 2.8 & 0.26 & 0.134 \\
\hline & & Canopy Cover & & & & NS \\
\hline & & Basin Area & & & & NS \\
\hline & & Full Model & 9 & 2.8 & 0.26 & 0.134 \\
\hline \multirow[t]{3}{*}{ Spring } & $\%$ Gatherer & Alkalinity & 7 & 21.6 & 0.78 & 0.004 \\
\hline & & $\begin{array}{c}\text { Canopy Cover } \\
\text { Basin Area }\end{array}$ & 7 & 3.8 & 0.10 & $\begin{array}{c}0.101 \\
\text { NS }\end{array}$ \\
\hline & & Full Model & 7 & 17.7 & 0.88 & 0.005 \\
\hline \multirow[t]{4}{*}{ Summer } & & Alkalinity & & & & NS \\
\hline & & Canopy Cover & & & & NS \\
\hline & & Basin Area & & & & NS \\
\hline & & Full Model & & & & NS \\
\hline
\end{tabular}


Table 4. Continued.

\begin{tabular}{|c|c|c|c|c|c|c|}
\hline Season & $\begin{array}{l}\text { Response } \\
\text { Variable }\end{array}$ & $\begin{array}{l}\text { Predictor } \\
\text { Variable }\end{array}$ & DF & F-value & $\mathrm{R}^{2}$ & $P$-value \\
\hline \multirow[t]{4}{*}{ Fall } & $\%$ Gatherer & Alkalinity & & & & NS \\
\hline & & Canopy Cover & & & & NS \\
\hline & & Basin Area & & & & NS \\
\hline & & Full Model & & & & NS \\
\hline \multirow[t]{4}{*}{ Annual } & & Alkalinity & & & & NS \\
\hline & & Canopy Cover & & & & NS \\
\hline & & Basin Area & & & & NS \\
\hline & & Full Model & & & & NS \\
\hline \multirow[t]{4}{*}{ Spring } & $\%$ Filterer & Alkalinity & & & & NS \\
\hline & & Canopy Cover & & & & NS \\
\hline & & Basin Area & & & & NS \\
\hline & & Full Model & & & & NS \\
\hline \multirow[t]{3}{*}{ Summer } & & Alkalinity & & & & NS \\
\hline & & Canopy Cover & 7 & 28.5 & 0.83 & 0.002 \\
\hline & & $\begin{array}{l}\text { Basin Area } \\
\text { Full Model }\end{array}$ & 7 & 28.5 & 0.83 & 0.002 \\
\hline \multirow[t]{4}{*}{ Fall } & & Alkalinity & & & & NS \\
\hline & & Canopy Cover & & & & NS \\
\hline & & Basin Area & & & & NS \\
\hline & & Full Model & & & & NS \\
\hline \multirow[t]{4}{*}{ Annual } & & Alkalinity & & & & NS \\
\hline & & Canopy Cover & & & & NS \\
\hline & & Basin Area & & & & NS \\
\hline & & Full Model & & & & NS \\
\hline \multirow[t]{4}{*}{ Spring } & $\%$ Predator & Alkalinity & & & & NS \\
\hline & & Canopy Cover & & & & NS \\
\hline & & Basin Area & & & & NS \\
\hline & & Full Model & & & & NS \\
\hline \multirow[t]{4}{*}{ Summer } & & Alkalinity & 7 & 5.0 & 0.45 & 0.067 \\
\hline & & Canopy Cover & & & & NS \\
\hline & & Basin Area & & & & NS \\
\hline & & Full Model & 7 & 5.0 & 0.45 & 0.067 \\
\hline \multirow[t]{4}{*}{ Fall } & & Alkalinity & & & & NS \\
\hline & & Canopy Cover & & & & NS \\
\hline & & Basin Area & & & & NS \\
\hline & & Full Model & & & & NS \\
\hline \multirow[t]{4}{*}{ Annual } & & Alkalinity & & & & NS \\
\hline & & Canopy Cover & & & & NS \\
\hline & & Basin Area & & & & NS \\
\hline & & Full Model & & & & NS \\
\hline
\end{tabular}

$\mathrm{NS}=$ no significance in model $(P>0.15)$. 
Table 5. Contribution of individual families to the percent biomass of feeding groups along a $\mathbf{2 5 . 2}$ km continuum of the Upper Shavers Fork, WV, May - October 2000.

\begin{tabular}{|c|c|c|c|c|c|c|c|}
\hline \multirow[b]{2}{*}{ Site } & \multicolumn{3}{|c|}{ Shredder } & \multirow{2}{*}{$\begin{array}{l}\text { Scraper } \\
\text { Family }\end{array}$} & \multicolumn{3}{|c|}{ Gatherer } \\
\hline & Season & Family & $\%$ & & $\%$ & Family & $\%$ \\
\hline \multirow[t]{3}{*}{1} & Spring & ND & & ND & & ND & \\
\hline & Summer & ND & & ND & & ND & \\
\hline & Fall & Leuctridae & 65 & Heptageniidae & 87 & Ephemerellidae & 59 \\
\hline \multirow[t]{3}{*}{ II } & Spring & ND & & ND & & ND & \\
\hline & Summer & ND & & ND & & ND & \\
\hline & Fall & Pteronarcyidae & 62 & Psychomyiidae & 56 & Chironomidae & 32 \\
\hline \multirow[t]{3}{*}{ III } & Spring & Leuctridae & 88 & Heptageniidae & 99 & Chironomidae & 60 \\
\hline & Summer & Leuctridae & 68 & Heptageniidae & 50 & Chironomidae & 47 \\
\hline & Fall & Leuctridae & 47 & Heptageniidae & 59 & Ephemerellidae & 82 \\
\hline \multirow[t]{3}{*}{ IV } & Spring & Leuctridae & 89 & Heptageniidae & 99 & Chironomidae & 90 \\
\hline & Summer & Leuctridae & 90 & Heptageniidae & 99 & Chironomidae & 79 \\
\hline & Fall & Capniidae & 30 & Elmidae & 59 & Chironomidae & 74 \\
\hline \multirow[t]{3}{*}{ V } & Spring & Leuctridae & 62 & Heptageniidae & 36 & Chironomidae & 96 \\
\hline & Summer & Leuctridae & 99 & Heptageniidae & 99 & Chironomidae & 73 \\
\hline & Fall & Leuctridae & 69 & Heptageniidae & 79 & Chironomidae & 45 \\
\hline \multirow[t]{3}{*}{$\mathrm{VI}$} & Spring & Leuctridae & 89 & Heptageniidae & 83 & Chironomidae & 73 \\
\hline & Summer & Leuctridae & 99 & Heptageniidae & 53 & Chironomidae & 87 \\
\hline & Fall & Peltoperlidae & 47 & Heptageniidae & 97 & Chironomidae & 46 \\
\hline \multirow[t]{3}{*}{ VII } & Spring & Leuctridae & 97 & Heptageniidae & 92 & Tiplulidae & 53 \\
\hline & Summer & Leuctridae & 95 & Heptageniidae & 75 & Chironomidae & 75 \\
\hline & Fall & Leuctridae & 43 & Heptageniidae & 49 & Tipulidae & 45 \\
\hline \multirow[t]{3}{*}{ VIII } & Spring & Leuctridae & 99 & Heptageniidae & 69 & Ephemeridae & 37 \\
\hline & Summer & Leuctridae & 97 & Heptageniidae & 93 & Ephemeridae & 36 \\
\hline & Fall & Leuctridae & 85 & Heptageniidae & 86 & Leptophlebiidae & 42 \\
\hline \multirow[t]{3}{*}{ IX } & Spring & Leuctridae & 97 & Heptageniidae & 93 & Chironomidae & 35 \\
\hline & Summer & Leuctridae & 94 & Psephenidae & 50 & Chironomidae & 64 \\
\hline & Fall & Pteronarcyidae & 82 & Heptageniidae & 92 & Leptophlebiidae & 37 \\
\hline \multirow[t]{3}{*}{$X$} & Spring & Leuctridae & 71 & Heptageniidae & 73 & Chironomidae & 52 \\
\hline & Summer & Pteronarcyidae & 84 & Odontoceridae & 61 & Chironomidae & 39 \\
\hline & Fall & Pteronarcyidae & 95 & Heptageniidae & 90 & Ephemerellidae & 25 \\
\hline
\end{tabular}

$\%=$ Percent of total biomass $\left(\mathrm{mgDM} / \mathrm{m}^{2}\right)$.

$(\mathrm{ND}=$ no data. Sites I-II data collected and presented for the fall season only.) 
Table 5. Continued.

\begin{tabular}{|c|c|c|c|c|c|}
\hline \multirow[b]{2}{*}{ Site } & \multirow[b]{2}{*}{ Season } & \multicolumn{2}{|l|}{ Filterer } & \multicolumn{2}{|l|}{ Predator } \\
\hline & & Family & $\%$ & Family & $\%$ \\
\hline \multirow[t]{3}{*}{1} & Spring & ND & & ND & \\
\hline & Summer & ND & & ND & \\
\hline & Fall & Hydropsychidae & 67 & Perlodidae & 56 \\
\hline \multirow[t]{3}{*}{ II } & Spring & ND & & ND & \\
\hline & Summer & ND & & ND & \\
\hline & Fall & Polycentropodidae & 86 & Chloroperlidae & 51 \\
\hline \multirow[t]{3}{*}{ III } & Spring & Polycentropodidae & 94 & Perlodidae & 91 \\
\hline & Summer & Polycentropodidae & 100 & Ceratopogonidae & 53 \\
\hline & Fall & Hydropsychidae & 82 & Perlodidae & 73 \\
\hline \multirow[t]{3}{*}{ IV } & Spring & Polycentropodidae & 100 & Perlodidae & 75 \\
\hline & Summer & Polycentropodidae & 100 & Chloroperlidae & 56 \\
\hline & Fall & Polycentropodidae & 90 & Chloroperlidae & 58 \\
\hline \multirow[t]{3}{*}{ V } & Spring & Polycentropodidae & 100 & Chloroperlidae & 65 \\
\hline & Summer & Polycentropodidae & 100 & Chloroperlidae & 74 \\
\hline & Fall & Polycentropodidae & 100 & Gomphidae & 84 \\
\hline \multirow[t]{3}{*}{ VI } & Spring & Hydropsychidae & 61 & Gomphidae & 64 \\
\hline & Summer & Polycentropodidae & 99 & Chloroperlidae & 92 \\
\hline & Fall & Polycentropodidae & 75 & Chloroperlidae & 61 \\
\hline \multirow[t]{3}{*}{ VII } & Spring & Polycentropodidae & 100 & Gomphidae & 71 \\
\hline & Summer & Hydropsychidae & 56 & Chloroperlidae & 81 \\
\hline & Fall & Hydropsychidae & 67 & Chloroperlidae & 63 \\
\hline \multirow[t]{3}{*}{ VIII } & Spring & Polycentropodidae & 69 & Chloroperlidae & 37 \\
\hline & Summer & Isonychiidae & 72 & Corydalidae & 57 \\
\hline & Fall & Hydropsychidae & 75 & Perlidae & 37 \\
\hline \multirow[t]{3}{*}{ IX } & Spring & Isonychiidae & 59 & Perlidae & 29 \\
\hline & Summer & Hydropsychidae & 62 & Corydalidae & 41 \\
\hline & Fall & Hydropsychidae & 73 & Perlodidae & 33 \\
\hline \multirow[t]{3}{*}{$X$} & Spring & Polycentropodidae & 53 & Corydalidae & 61 \\
\hline & Summer & Polycentropodidae & 37 & Gomphidae & 38 \\
\hline & Fall & Hydropsychidae & 50 & Perlidae & 61 \\
\hline
\end{tabular}

$\%=$ Percent of total biomass $\left(\mathrm{mgDM} / \mathrm{m}^{2}\right)$.

(ND = no data. Sites I-II data collected and presented for the fall season only.) 
Table 6. Response of absolute biomass of feeding groups to the effects of alkalinity, canopy cover, and basin area along a $25.2 \mathrm{~km}$ continuum of the Upper Shavers Fork, WV, May - October 2000.

\begin{tabular}{|c|c|c|c|c|c|c|}
\hline Season & $\begin{array}{l}\text { Response } \\
\text { Variable }\end{array}$ & $\begin{array}{l}\text { Predictor } \\
\text { Variable }\end{array}$ & DF & F-value & $\mathrm{R}^{2}$ & $P$-value \\
\hline \multirow[t]{4}{*}{ Spring } & Shredder & Alkalinity & & & & NS \\
\hline & & Canopy Cover & & & & NS \\
\hline & & Basin Area & & & & NS \\
\hline & & Full Model & & & & NS \\
\hline \multirow[t]{4}{*}{ Summer } & & Alkalinity & & & & NS \\
\hline & & Canopy Cover & & & & NS \\
\hline & & Basin Area & & & & NS \\
\hline & & Full Model & & & & NS \\
\hline \multirow[t]{4}{*}{ Fall } & & Alkalinity & & & & NS \\
\hline & & Canopy Cover & & & & NS \\
\hline & & Basin Area & & & & NS \\
\hline & & Full Model & & & & NS \\
\hline \multirow[t]{4}{*}{ Annual } & & Alkalinity & & & & NS \\
\hline & & Canopy Cover & & & & NS \\
\hline & & Basin Area & 9 & 3.7 & 0.32 & 0.091 \\
\hline & & Full Model & 9 & 3.7 & 0.32 & 0.091 \\
\hline \multirow[t]{3}{*}{ Spring } & Scraper & Alkalinity & & & & NS \\
\hline & & $\begin{array}{l}\text { Canopy Cover } \\
\text { Basin Area }\end{array}$ & 7 & 3.1 & 0.34 & 0.127 \\
\hline & & Full Model & 7 & 3.1 & 0.34 & 0.127 \\
\hline \multirow[t]{4}{*}{ Summer } & & Alkalinity & 7 & 3.5 & 0.37 & 0.110 \\
\hline & & Canopy Cover & & & & NS \\
\hline & & Basin Area & & & & NS \\
\hline & & Full Model & 7 & 3.5 & 0.37 & 0.110 \\
\hline \multirow[t]{4}{*}{ Fall } & & Alkalinity & & & & NS \\
\hline & & Canopy Cover & 7 & 5.3 & 0.40 & 0.050 \\
\hline & & Basin Area & & & & NS \\
\hline & & Full Model & 7 & 5.3 & 0.40 & 0.050 \\
\hline \multirow[t]{4}{*}{ Annual } & & Alkalinity & & & & NS \\
\hline & & Canopy Cover & 9 & 79.0 & 0.54 & $<0.001$ \\
\hline & & Basin Area & 9 & 5.6 & 0.41 & 0.045 \\
\hline & & Full Model & 9 & 69.7 & 0.95 & $<0.001$ \\
\hline \multirow[t]{4}{*}{ Spring } & Gatherer & Alkalinity & 7 & 110.1 & 0.95 & $<0.001$ \\
\hline & & Canopy Cover & & & & NS \\
\hline & & Basin Area & & & & NS \\
\hline & & Full Model & 7 & 110.1 & 0.95 & $<0.001$ \\
\hline \multirow[t]{4}{*}{ Summer } & & Alkalinity & 7 & 5.5 & 0.48 & 0.057 \\
\hline & & Canopy Cover & & & & NS \\
\hline & & Basin Area & 7 & 4.7 & 0.25 & 0.082 \\
\hline & & Full Model & 7 & 6.8 & 0.73 & 0.037 \\
\hline
\end{tabular}


Table 6. Continued.

\begin{tabular}{|c|c|c|c|c|c|c|}
\hline Season & $\begin{array}{c}\text { Response } \\
\text { Variable }\end{array}$ & $\begin{array}{l}\text { Predictor } \\
\text { Variable }\end{array}$ & DF & F-value & $\mathrm{R}^{2}$ & $P$-value \\
\hline Fall & Gatherer & $\begin{array}{c}\text { Alkalinity } \\
\text { Canopy Cover } \\
\text { Basin Area } \\
\text { Full Model }\end{array}$ & 7 & 10.1 & 0.56 & $\begin{array}{c}0.13 \\
\text { NS } \\
\text { NS } \\
0.13\end{array}$ \\
\hline Annual & & $\begin{array}{c}\text { Alkalinity } \\
\text { Canopy Cover } \\
\text { Basin Area } \\
\text { Full Model }\end{array}$ & $\begin{array}{l}9 \\
9 \\
9\end{array}$ & $\begin{array}{c}30.2 \\
3.3 \\
22.7\end{array}$ & $\begin{array}{l}0.58 \\
0.29 \\
0.87\end{array}$ & $\begin{array}{c}\text { NS } \\
0.001 \\
0.108 \\
0.001\end{array}$ \\
\hline Spring & Filterer & $\begin{array}{c}\text { Alkalinity } \\
\text { Canopy Cover } \\
\text { Basin Area } \\
\text { Full Model }\end{array}$ & 7 & 4.9 & 0.45 & $\begin{array}{l}0.068 \\
N S \\
N S \\
0.068\end{array}$ \\
\hline Summer & & $\begin{array}{c}\text { Alkalinity } \\
\text { Canopy Cover } \\
\text { Basin Area } \\
\text { Full Model }\end{array}$ & 7 & 23.1 & 0.79 & $\begin{array}{l}0.003 \\
\text { NS } \\
\text { NS } \\
0.003\end{array}$ \\
\hline Fall & & $\begin{array}{c}\text { Alkalinity } \\
\text { Canopy Cover } \\
\text { Basin Area } \\
\text { Full Model }\end{array}$ & 7 & 8.5 & 0.51 & $\begin{array}{l}0.020 \\
\text { NS } \\
\text { NS } \\
0.020\end{array}$ \\
\hline Annual & & $\begin{array}{c}\text { Alkalinity } \\
\text { Canopy Cover } \\
\text { Basin Area } \\
\text { Full Model }\end{array}$ & $\begin{array}{l}9 \\
9 \\
9\end{array}$ & $\begin{array}{l}19.9 \\
19.2 \\
42.2\end{array}$ & $\begin{array}{l}0.22 \\
0.71 \\
0.92\end{array}$ & $\begin{array}{c}\text { NS } \\
0.003 \\
0.002 \\
<0.001\end{array}$ \\
\hline Spring & Predator & $\begin{array}{c}\text { Alkalinity } \\
\text { Canopy Cover } \\
\text { Basin Area } \\
\text { Full Model }\end{array}$ & $\begin{array}{l}7 \\
7\end{array}$ & $\begin{array}{l}4.3 \\
4.3\end{array}$ & $\begin{array}{l}0.42 \\
0.42\end{array}$ & $\begin{array}{c}\text { NS } \\
0.082 \\
N S \\
0.082\end{array}$ \\
\hline Summer & & $\begin{array}{c}\text { Alkalinity } \\
\text { Canopy Cover } \\
\text { Basin Area } \\
\text { Full Model }\end{array}$ & 7 & 23.8 & 0.80 & $\begin{array}{l}0.003 \\
\text { NS } \\
\text { NS } \\
0.003\end{array}$ \\
\hline Fall & & $\begin{array}{c}\text { Alkalinity } \\
\text { Canopy Cover } \\
\text { Basin Area } \\
\text { Full Model }\end{array}$ & 7 & $\begin{array}{l}12.9 \\
12.9\end{array}$ & $\begin{array}{l}0.62 \\
0.62\end{array}$ & $\begin{array}{c}\text { NS } \\
0.007 \\
\text { NS } \\
0.007\end{array}$ \\
\hline Annual & & $\begin{array}{c}\text { Alkalinity } \\
\text { Canopy Cover } \\
\text { Basin Area } \\
\text { Full Model }\end{array}$ & $\begin{array}{l}9 \\
9 \\
9\end{array}$ & $\begin{array}{l}22.2 \\
28.5 \\
63.3\end{array}$ & $\begin{array}{l}0.17 \\
0.78 \\
0.95\end{array}$ & $\begin{array}{c}\text { NS } \\
0.002 \\
0.001 \\
<0.001\end{array}$ \\
\hline
\end{tabular}

$\mathrm{NS}=$ no significance in model $(P>0.15)$. 
Table 7. Annualized abundance of taxa in sites having the largest variation in alkalinity, canopy cover, and basin area along a $25.2 \mathrm{~km}$ continuum of the Upper Shavers Fork, WV, May - October 2000 .

Sites I - II

\begin{tabular}{cccccc}
\hline $\begin{array}{c}\text { Tolerant of } \\
\text { Acidity }\end{array}$ & Order & Family & Genera & $\begin{array}{c}\% \\
\text { Contribution }\end{array}$ & N \\
\hline No & Ephemeroptera & - & - & 56 & 2,312 (EPT) \\
Yes & Plecoptera & - & - & 37 & 2,312 (EPT) \\
No & Trichoptera & - & - & 07 & 2,312 (EPT) \\
No & Ephemeroptera & Leptophlebiidae & - & 22 & 1,304 (Order) \\
Yes & Ephemeroptera & Heptageniidae & Epeorus & 50 & 538 (Family) \\
Yes & Ephemeroptera & Ephemerellidae & Eurylophella & 01 & 130 (Family) \\
Yes & Trichoptera & Hydropsychidae & Parapsyche & 00 & 53 (Family) \\
\hline
\end{tabular}

Sites III - IV

\begin{tabular}{cccccc}
\hline $\begin{array}{c}\text { Tolerant of } \\
\text { Acidity }\end{array}$ & Order & Family & Genera & $\begin{array}{c}\% \\
\text { Contribution }\end{array}$ & N \\
\hline No & Ephemeroptera & - & - & 09 & 2,565 (EPT) \\
Yes & Plecoptera & - & - & 87 & 2,565 (EPT) \\
No & Trichoptera & - & - & 04 & 2,565 (EPT) \\
No & Ephemeroptera & Leptophlebiidae & - & 02 & 228 (Order) \\
Yes & Ephemeroptera & Heptageniidae & Epeorus & 38 & 61 (Family) \\
Yes & Ephemeroptera & Ephemerellidae & Eurylophella & 70 & 88 (Family) \\
Yes & Trichoptera & Hydropsychidae & Parapsyche & 100 & 16 (Family) \\
\hline
\end{tabular}

Sites VIII - X

\begin{tabular}{cccccc}
\hline Tolerant of & & & & $\%$ \\
Acidity & Order & Family & Genera & Contribution & N \\
\hline No & Ephemeroptera & - & - & 55 & 8,259 (EPT) \\
Yes & Plecoptera & - & - & 30 & 8,259 (EPT) \\
No & Trichoptera & - & - & 15 & 8,259 (EPT) \\
No & Ephemeroptera & Leptophlebiidae & - & 56 & 4,563 (Order) \\
Yes & Ephemeroptera & Heptageniidae & Epeorus & 11 & 454 (Family) \\
Yes & Ephemeroptera & Ephemerellidae & Eurylophella & 08 & 472 (Family) \\
Yes & Trichoptera & Hydropsychidae & Parapsyche & 00 & 535 (Family) \\
\hline
\end{tabular}

Sites I - II data collected and presented for fall season only, $\mathrm{N}=$ total abundance from five $0.1 \mathrm{~m}^{2}$ benthic samples. For all other sites, $\mathrm{N}=$ total abundance from fifteen $0.1 \mathrm{~m}^{2}$ benthic samples. $\mathrm{EPT}=$ Ephemeroptera:Plecoptera:Trichoptera. 
Table 8. Comparison of the abundance of acid-sensitive taxa occurring in four headwater sites differing in alkalinity in the Upper Shavers Fork, WV, October 2000.

\begin{tabular}{cccccc}
\hline Tol. & I & II & III & IV \\
Family & Val. & (n) & (n) & (n) & (n) \\
\hline Pteronarcyidae & 2 & 0 & 1 & 0 & 0 \\
Glossosomatidae & $0-2$ & 1 & 0 & 0 & 0 \\
Philopotamidae & $0-4$ & 4 & 1 & 0 & 0 \\
Gomphidae & $4-6$ & 2 & 3 & 0 & 0 \\
Perlodidae & $1-2$ & 15 & 34 & 3 & 9 \\
\hline
\end{tabular}

Tol.Val. $=$ Range of tolerance values for each family $(0=$ no tolerance $)$ (Stribling et al., 1998). I - IV (n) = Total abundance from five, $0.1 \mathrm{~m}^{2}$, benthic samples at sites I-IV.

Mean alkalinity $\left(\mathrm{mg} / \mathrm{L} \mathrm{CaCO}_{3}\right)$ for Site $\mathrm{I}=22.4$; Site II $=17.2$; Site III $=4.2$; and Site IV = 7.6. 


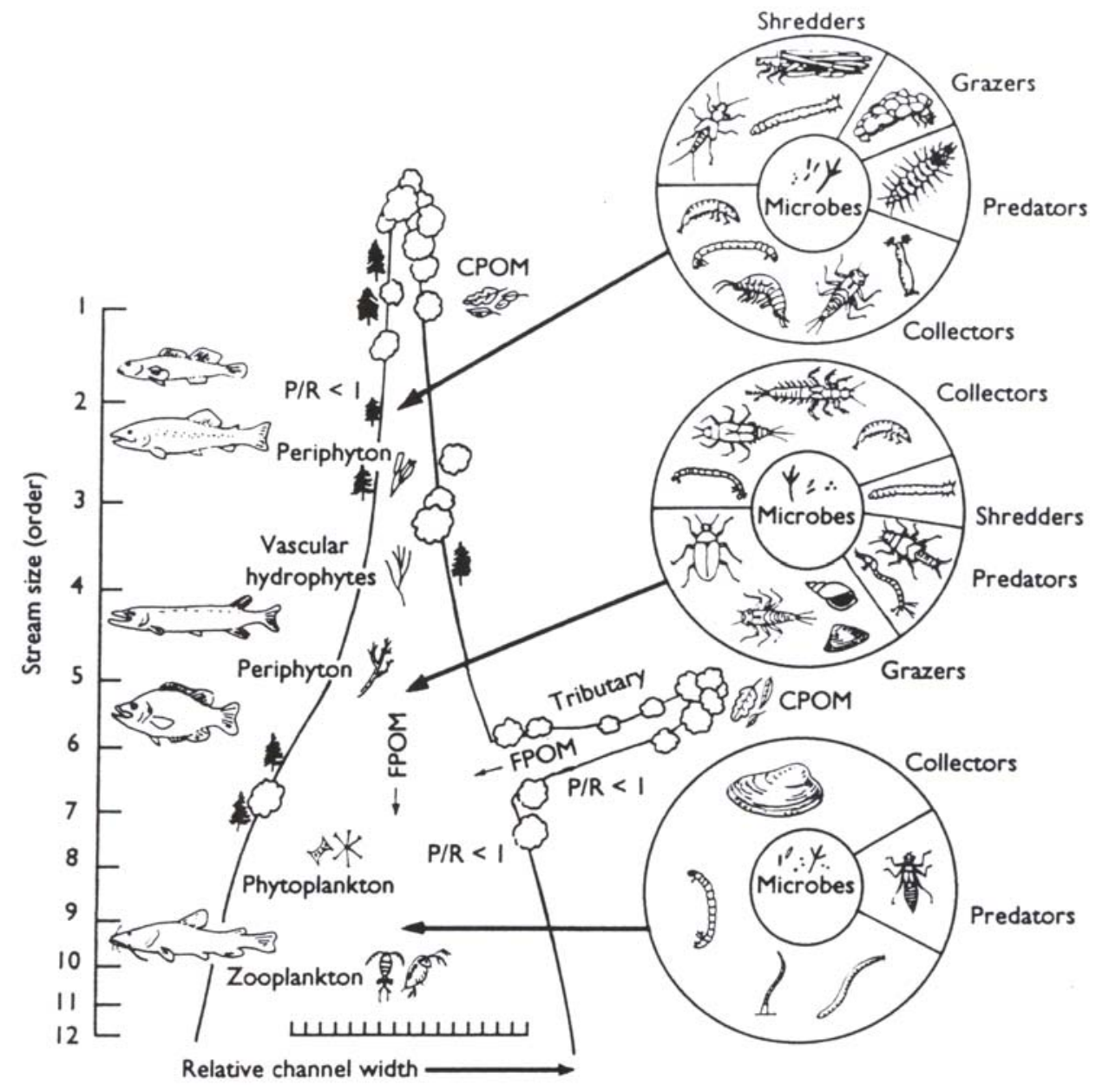

Figure 1. The River Continuum Concept with predicted changes in stream ecosystem communities along a hypothetical longitudinal gradient (From Vannote et al., 1980). 


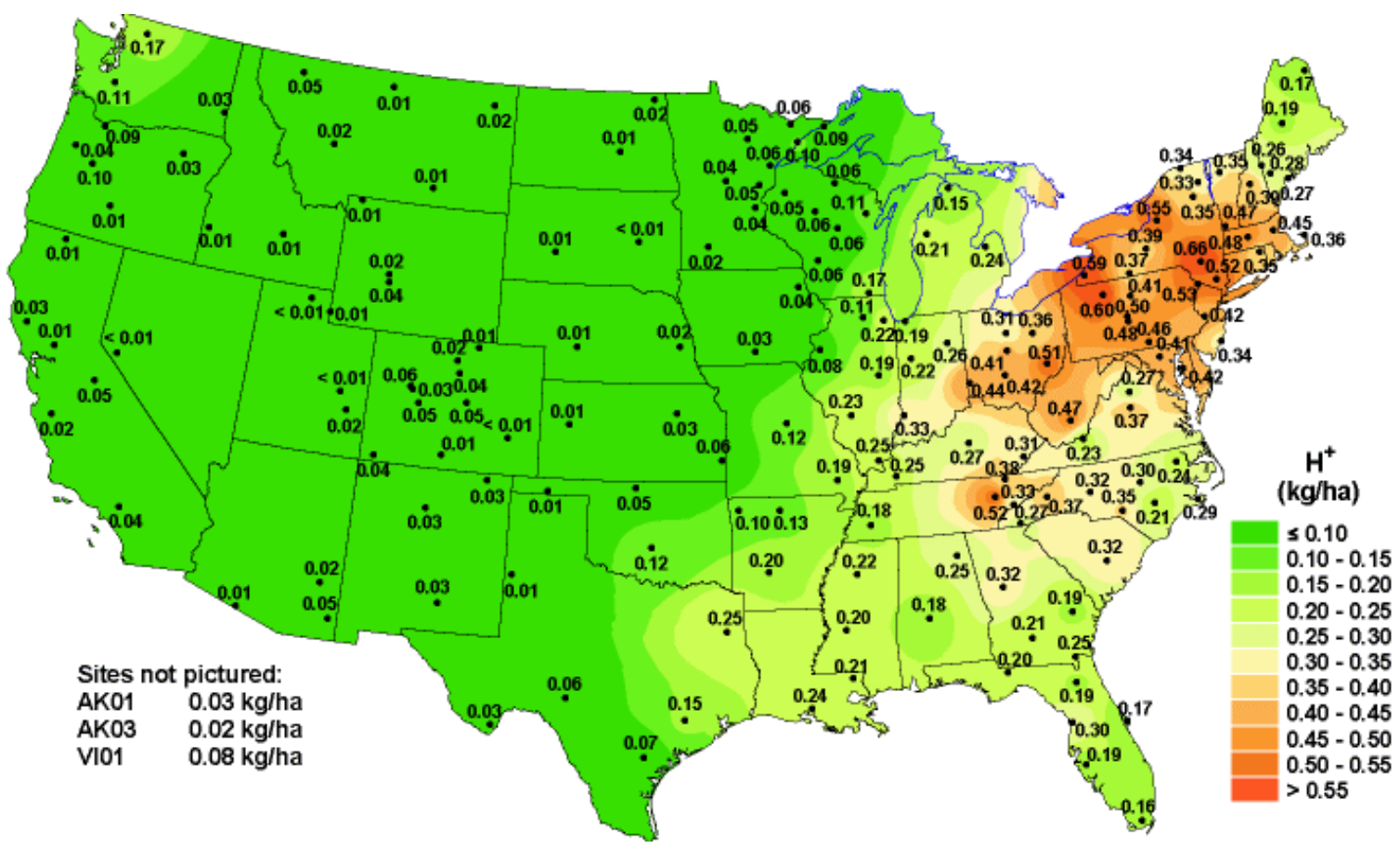

Figure 2. Hydrogen ion wet deposition for the United States in 2000. (From NADP, 2000). 


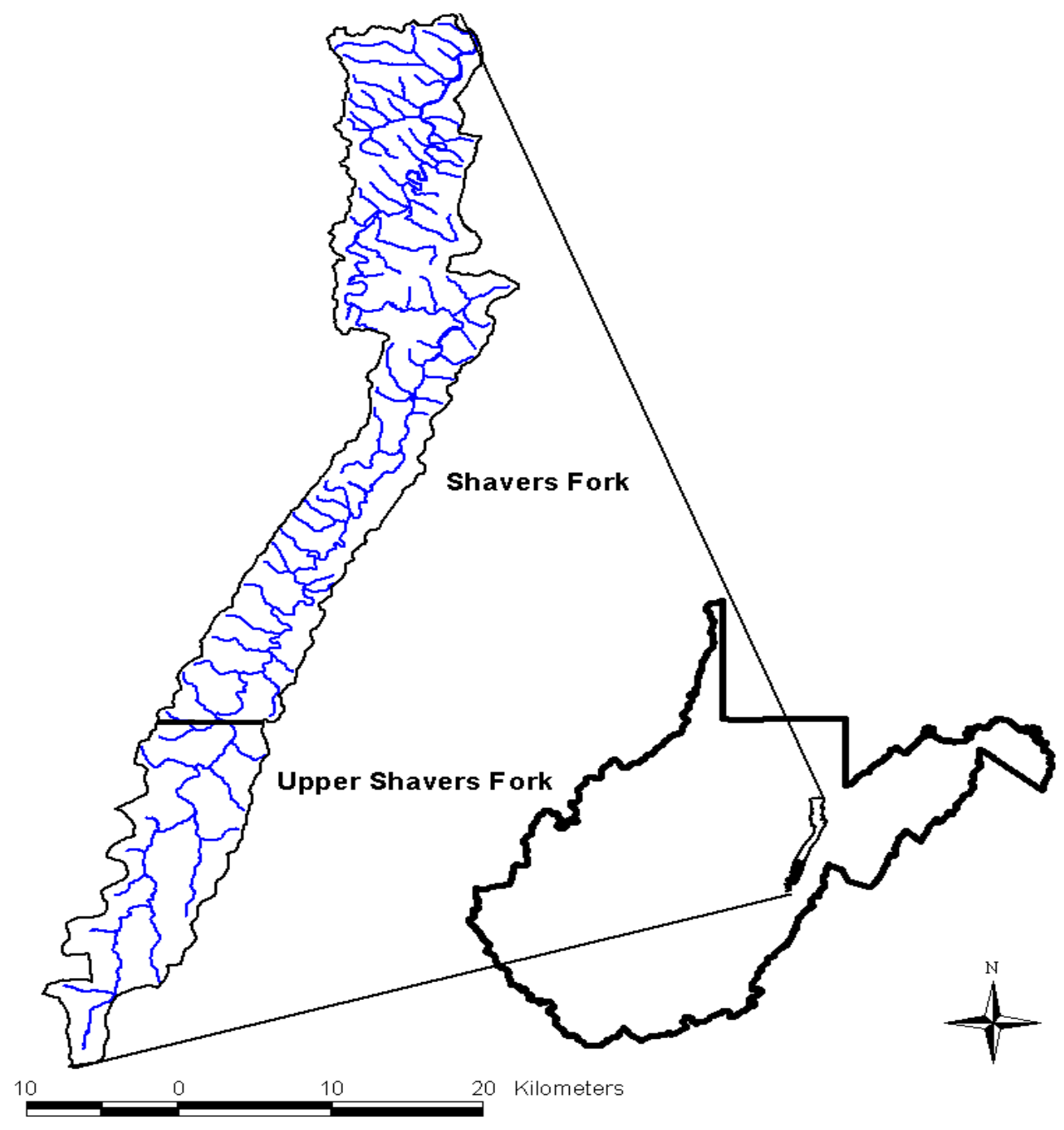

Figure 3. The Shavers Fork watershed with the Upper Shavers Fork subsection, WV, 2000. 


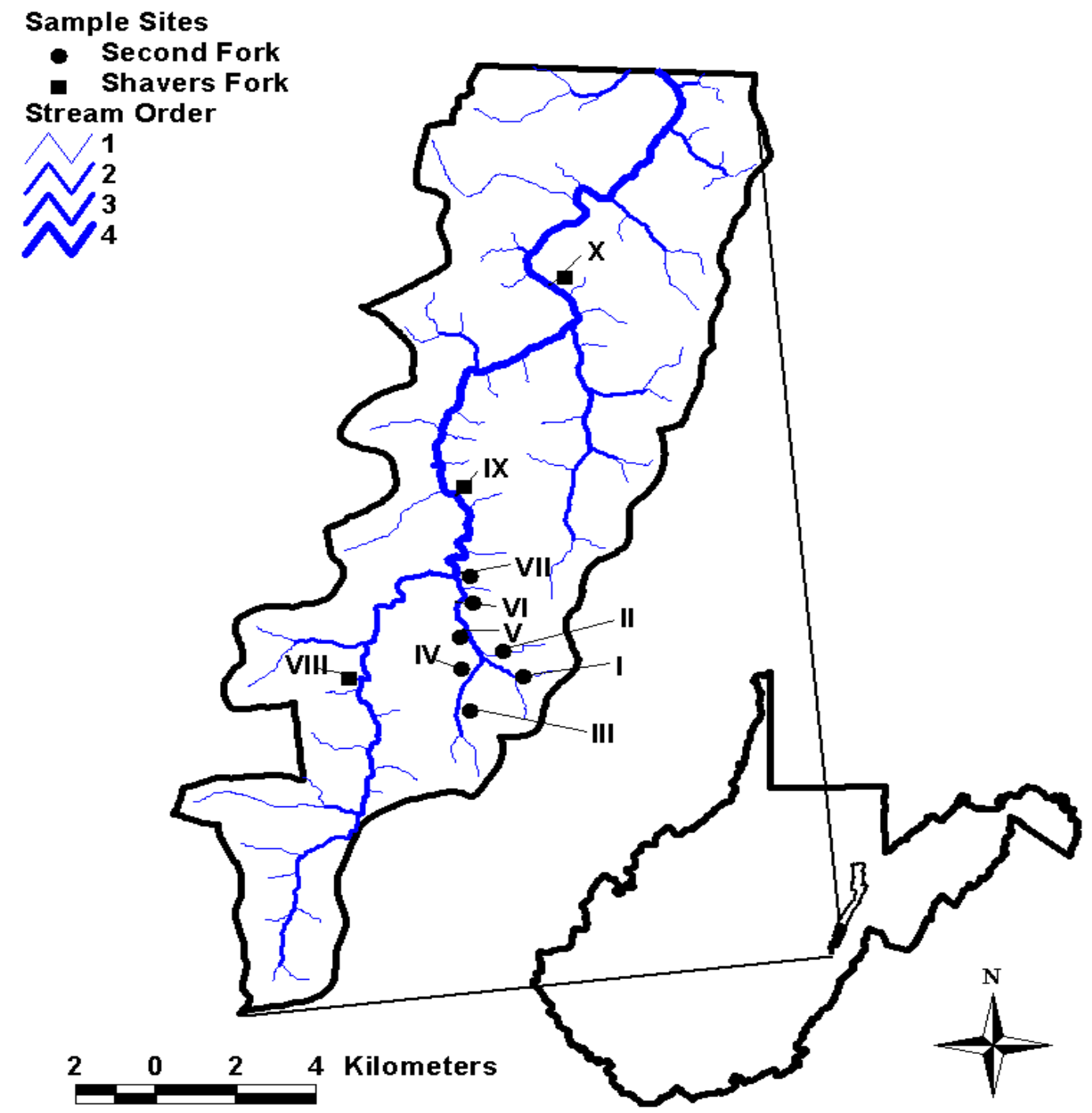

Figure 4. The Upper Shavers Fork watershed with sampling sites along a $25.2 \mathrm{~km}$ stream continuum, WV, 2000. 


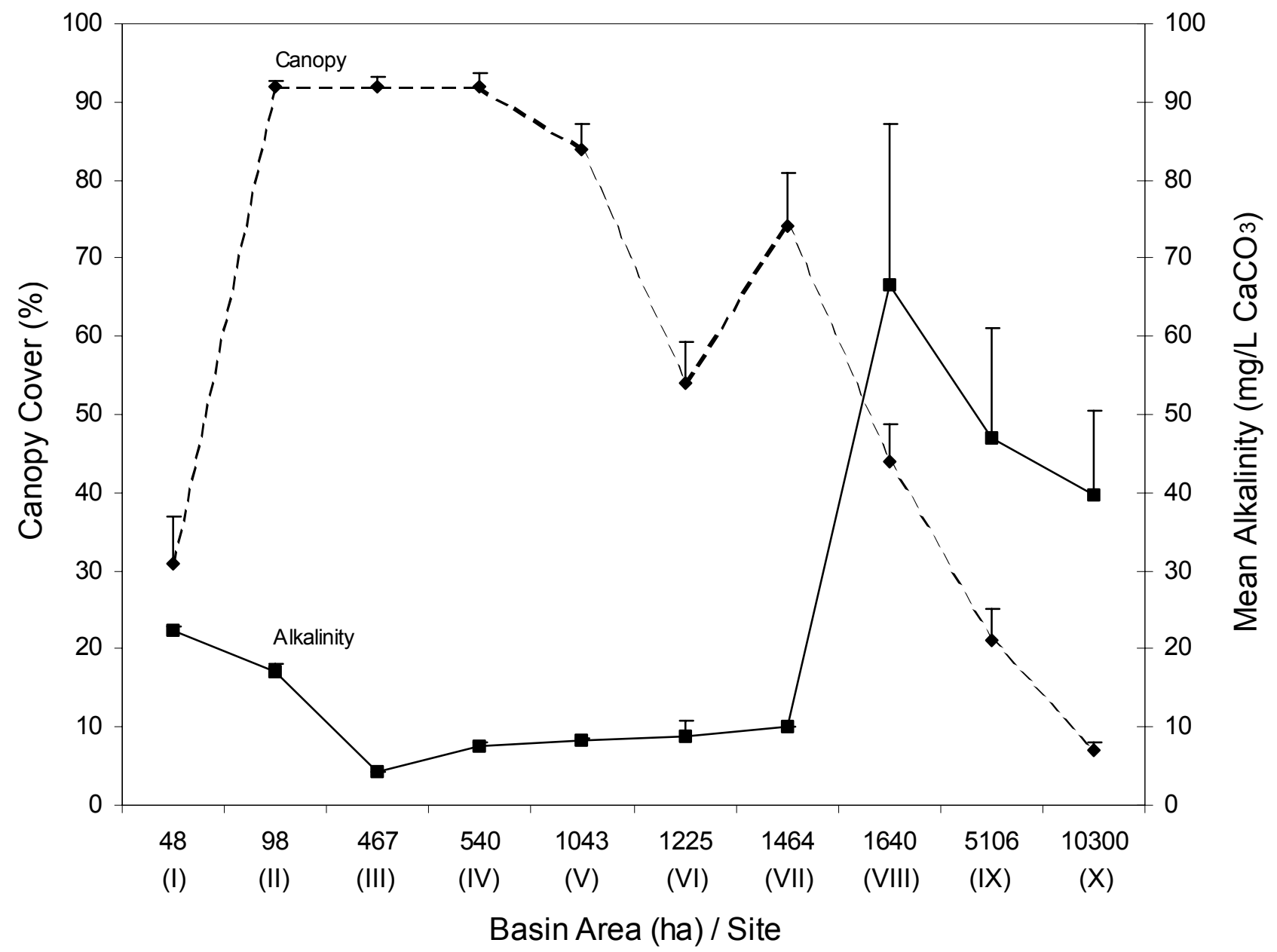

Figure 5. Relationship between basin area, canopy cover (+SE), and alkalinity (+SE) along a $25.2 \mathrm{~km}$ continuum of the Upper Shavers Fork, WV, May - October, 2000. 


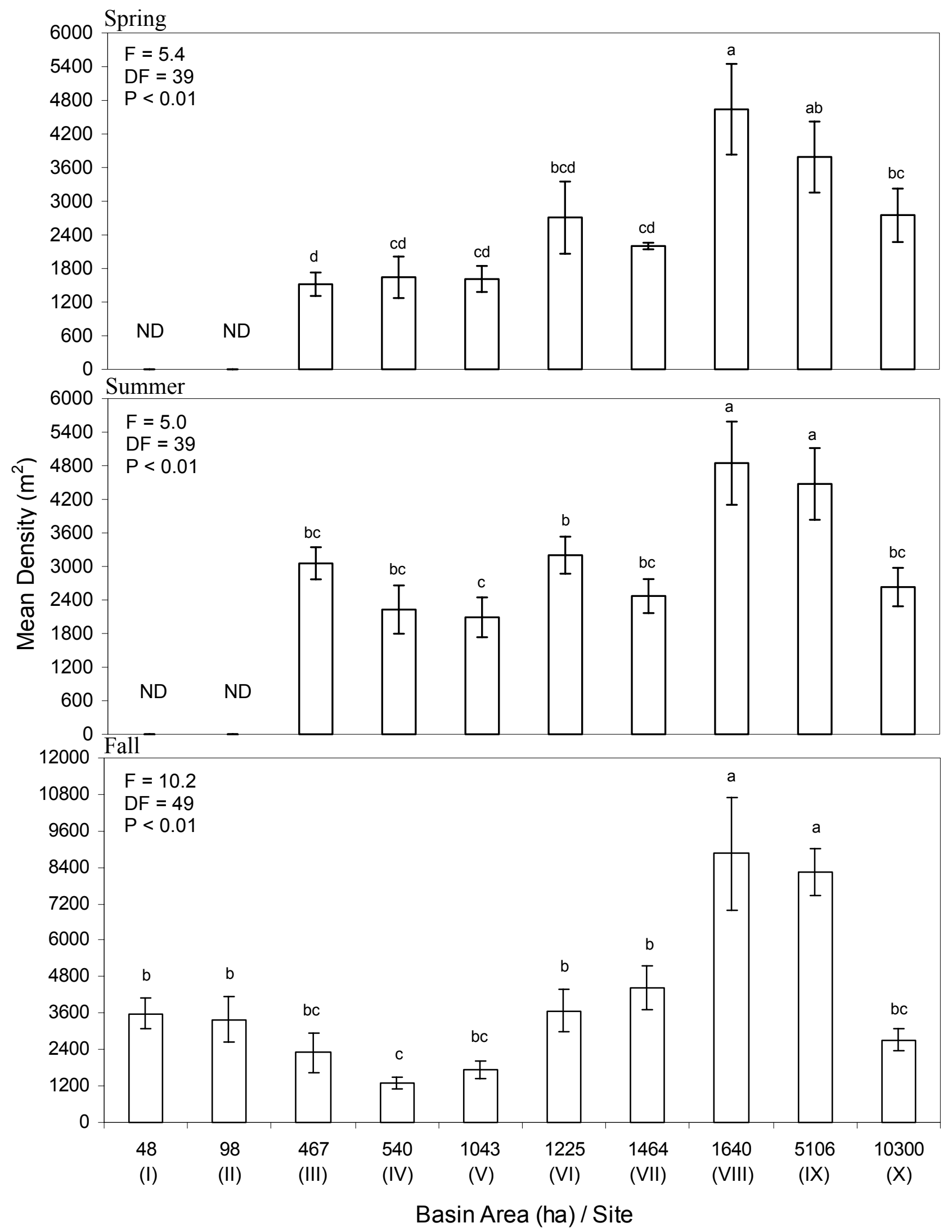

Figure 6. Mean $(n=5)$ density $( \pm \mathrm{SE})$ of benthic macroinvertebrates along a $25.2 \mathrm{~km}$ continuum of the Upper Shavers Fork, WV, May - October 2000. Sites sharing a common letter do not significantly differ $(P<0.10)$. $(\mathrm{ND}=$ no data collected $)$. 


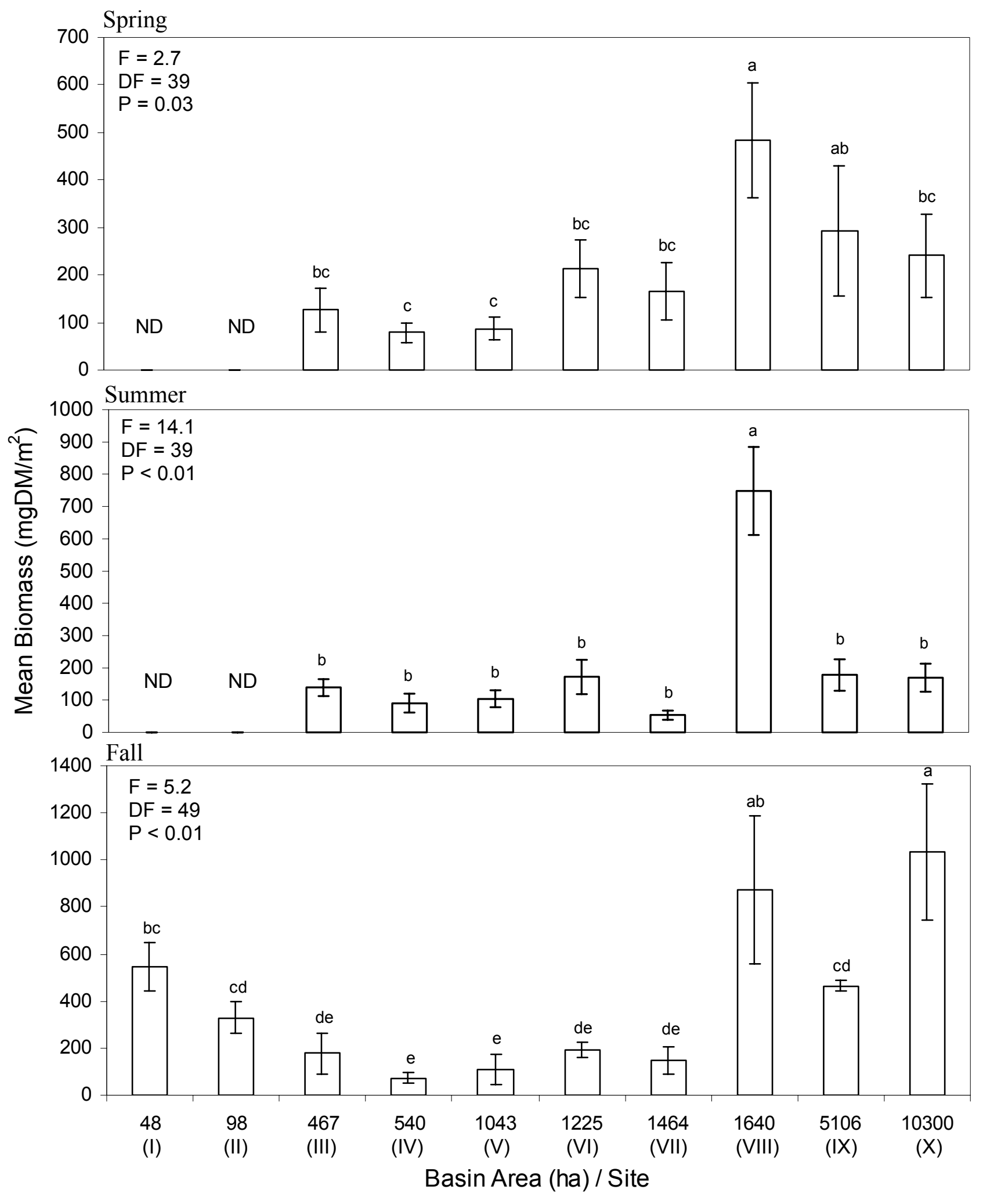

Figure 7. Mean $(n=5)$ biomass $( \pm \mathrm{SE})$ of benthic macroinvertebrates along a $25.2 \mathrm{~km}$ continuum of the Upper Shavers Fork, WV, May - October 2000. Sites sharing a common letter do not significantly differ $(P<0.10)$. $(\mathrm{ND}=$ no data collected $)$. 

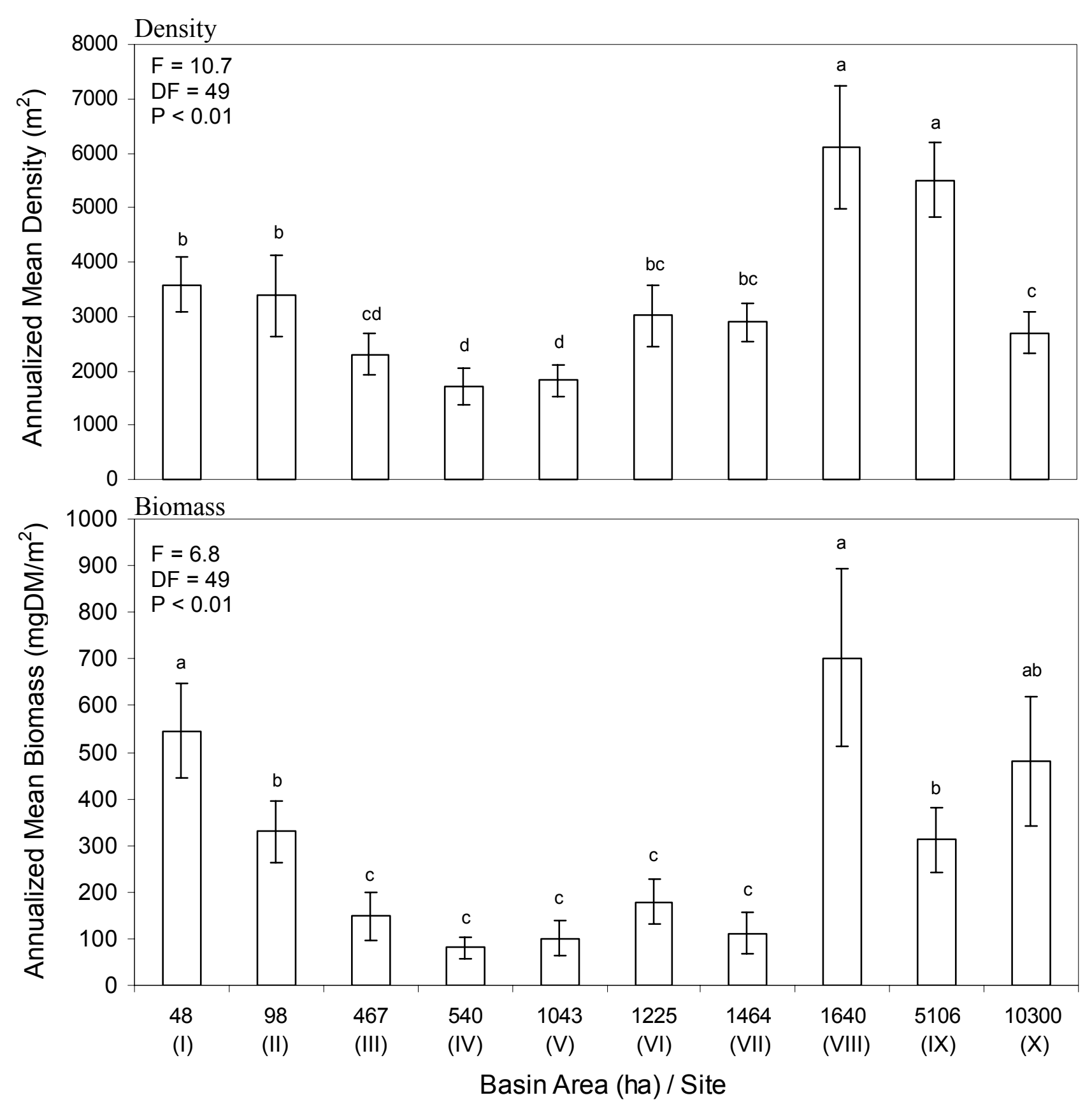

Figure 8. Annualized mean $(n=15)$ density $( \pm \mathrm{SE})$ and biomass $( \pm \mathrm{SE})$ for benthic macroinvertebrates along a $25.2 \mathrm{~km}$ continuum of the Upper Shavers Fork, WV, May - October 2000. Sites sharing a common letter do not significantly differ $(P<0.10)$. (Sites I-II data collected and presented for fall season only, $n=5$ ). 


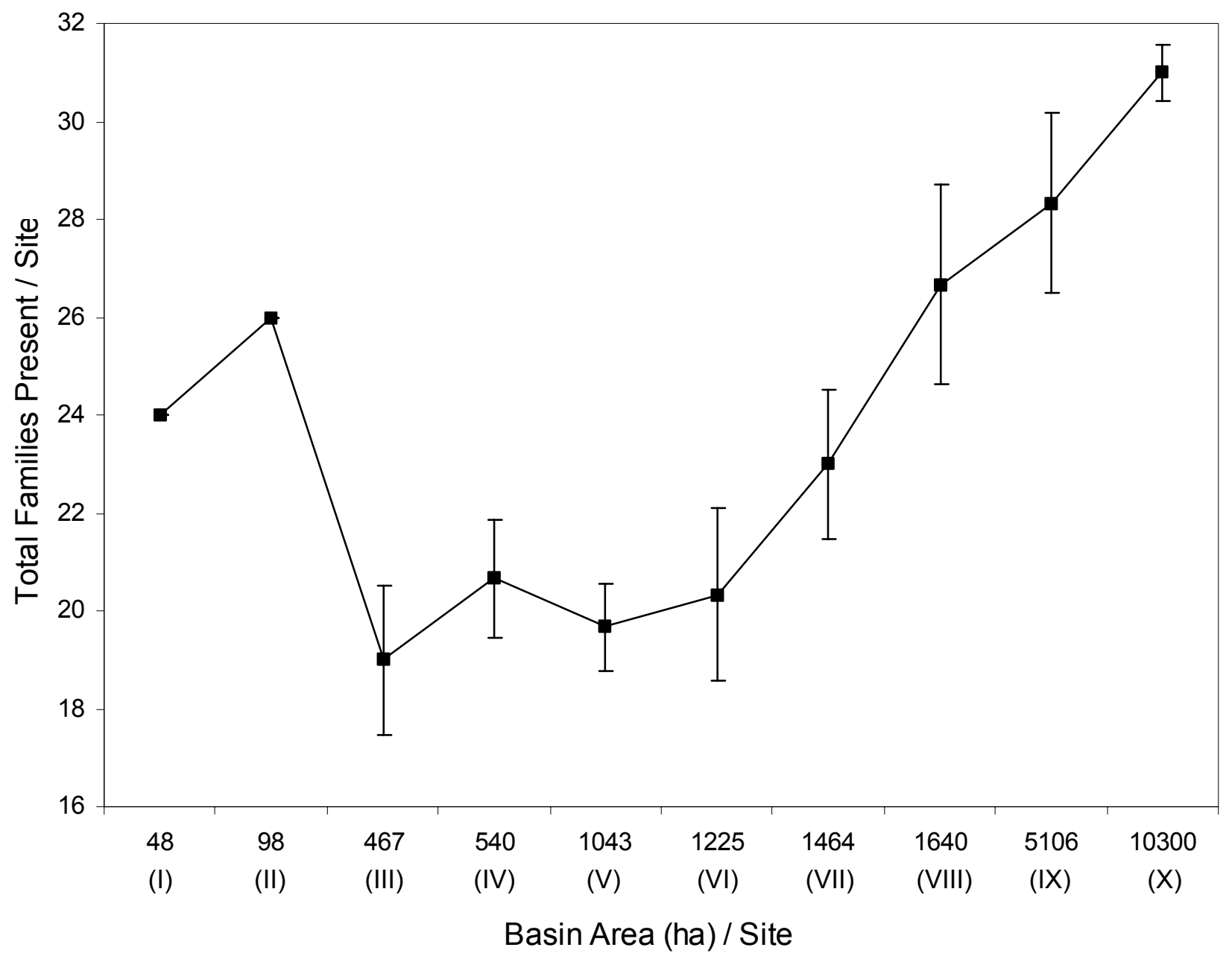

Figure 9. Annualized mean $(\mathrm{n}=3)$ macroinvertebrate family richness $( \pm \mathrm{SE})$ along a $25.2 \mathrm{~km}$ continuum of the Upper Shavers Fork, WV, May - October 2000. (Sites I-II data collected and presented for fall season only, $n=1$ ). 


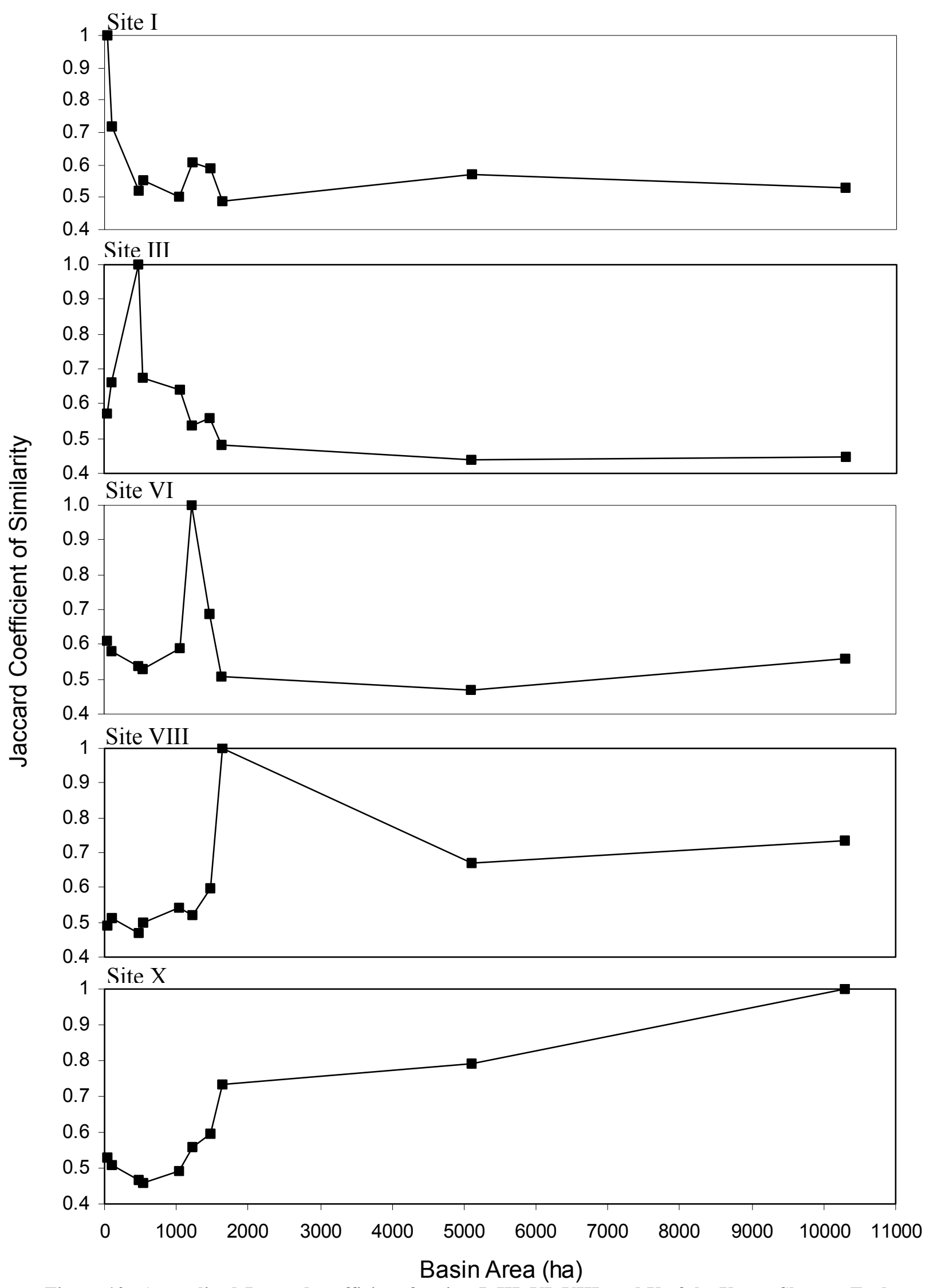

Figure 10. Annualized Jaccard coefficient for sites I, III, VI, VIII, and X of the Upper Shavers Fork, WV, May - October 2000. (Site I data collected and presented for fall season only). 
Spring
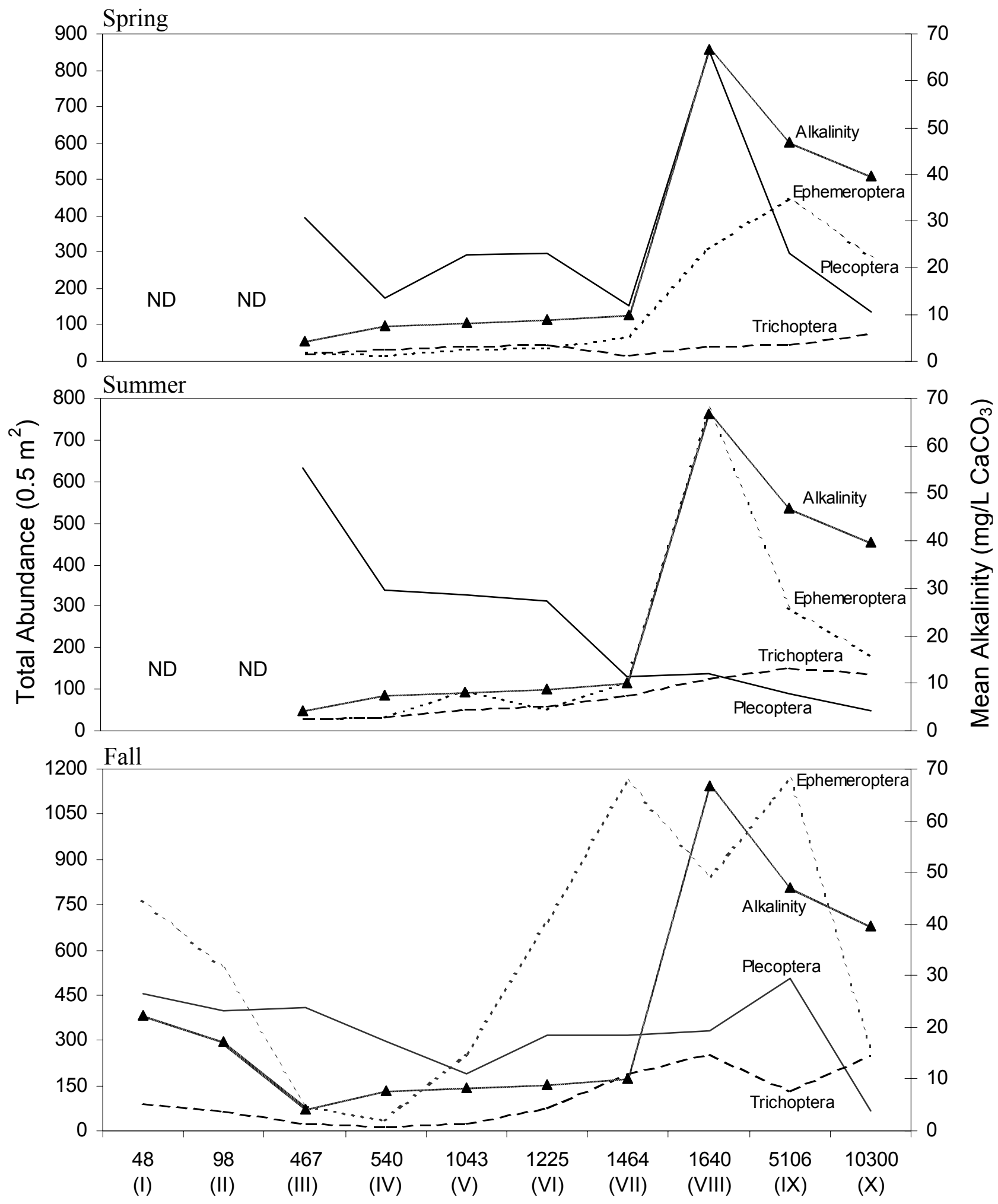

Basin Area (ha) / Site

Figure 11. Abundance of Ephemeroptera, Plecoptera, and Trichoptera along a $25.2 \mathrm{~km}$ continuum of the Upper Shavers Fork, WV, May - October 2000. (ND = no data. Sites I-II data collected and presented for fall season only.) 


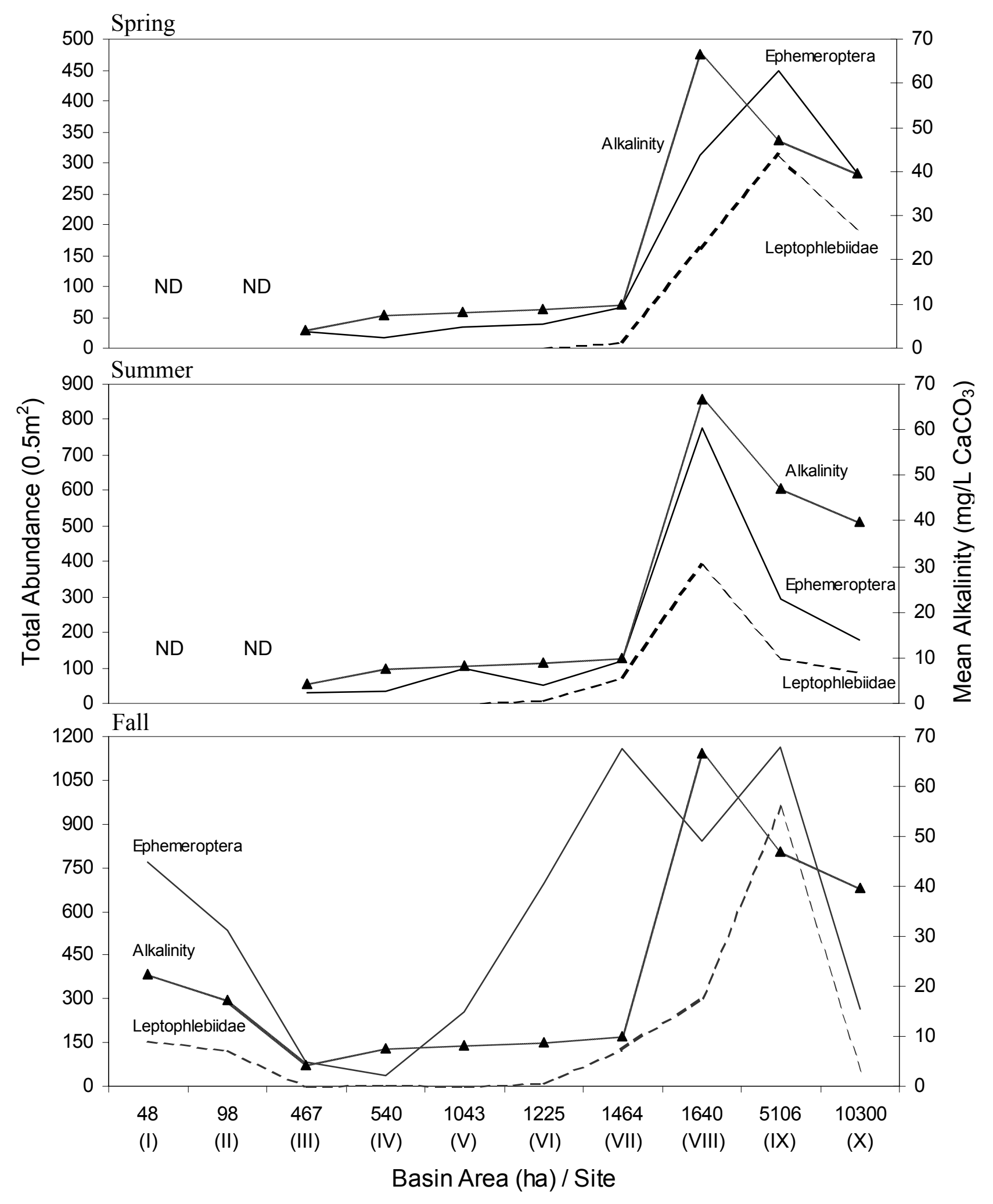

Figure 12. Abundance of Leptophlebiidae to Ephemeroptera along a $25.2 \mathrm{~km}$ continuum of the Upper Shavers Fork, WV, May - October 2000. (ND = no data. Sites I-II data collected and presented for fall season only.) 


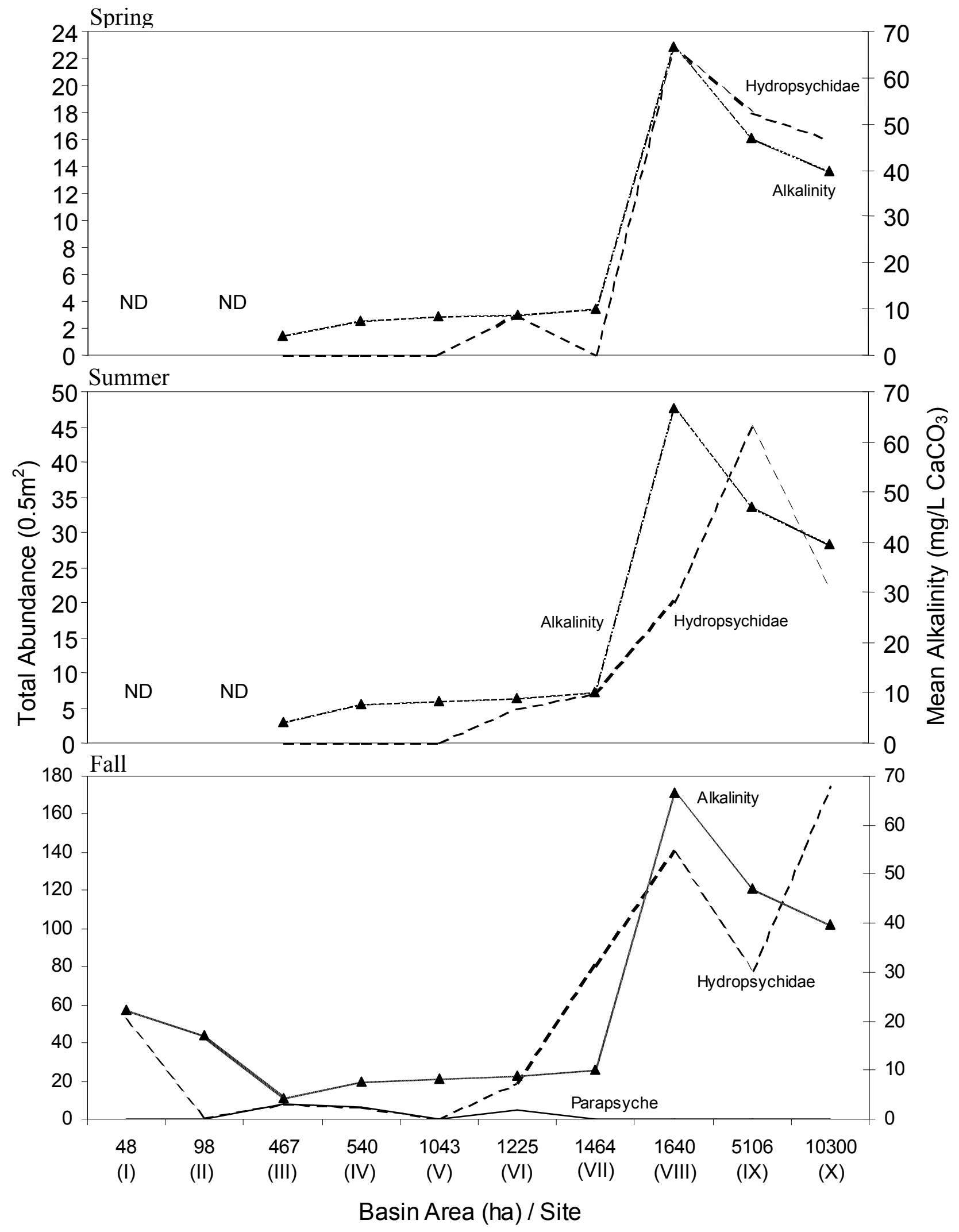

Figure 13. Abundance of Parapsyche spp. to Hydropsychidae along a $25.2 \mathrm{~km}$ continuum of the Upper Shavers Fork, WV, May - October 2000. (ND = no data. Sites I-II data collected and presented for fall season only.) 


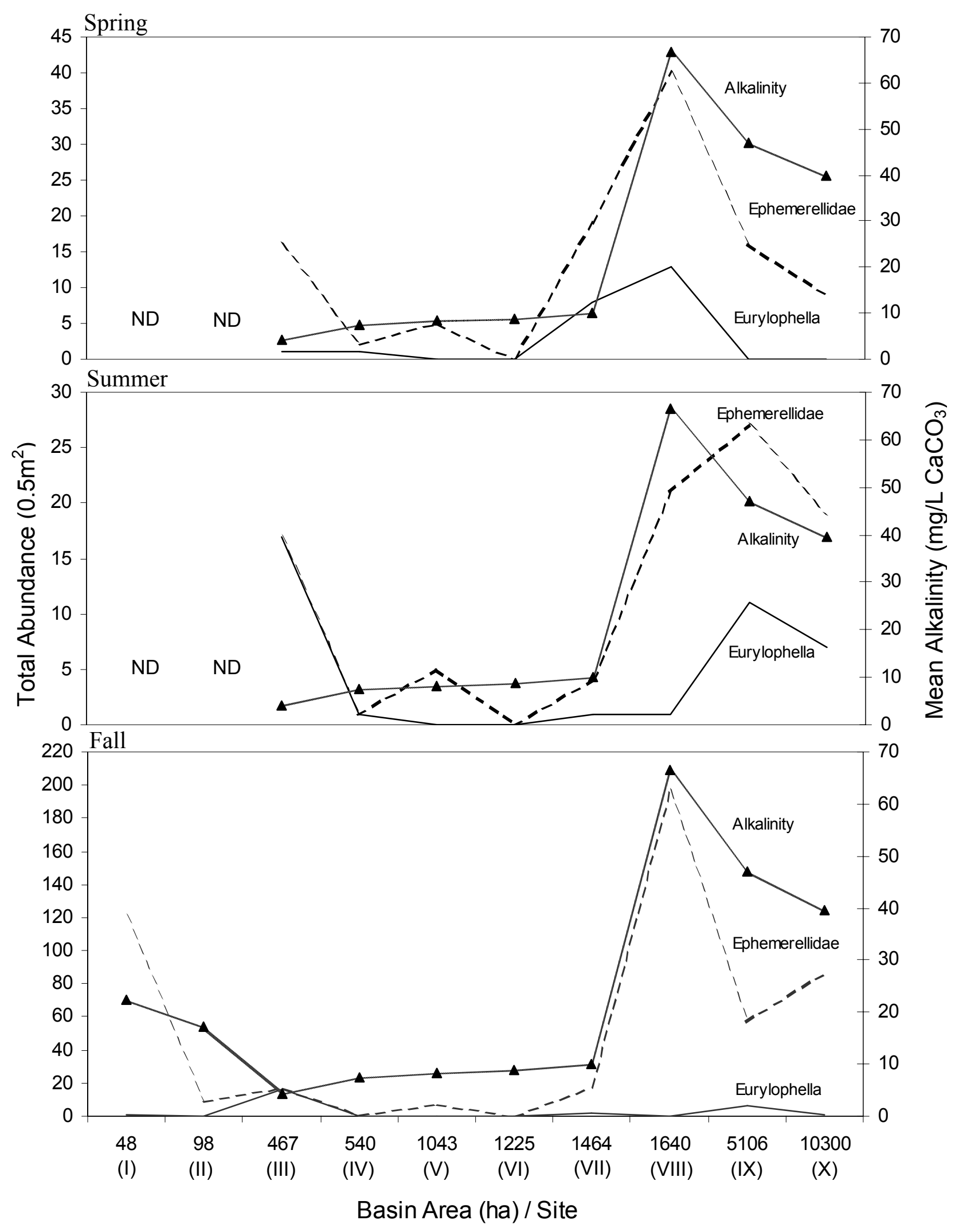

Figure 14. Abundance of Eurylophella spp. to Ephemerellidae along a $25.2 \mathrm{~km}$ continuum of the Upper Shavers Fork, WV, May - October 2000. (ND = no data. Sites I-II data collected and presented for fall season only.) 


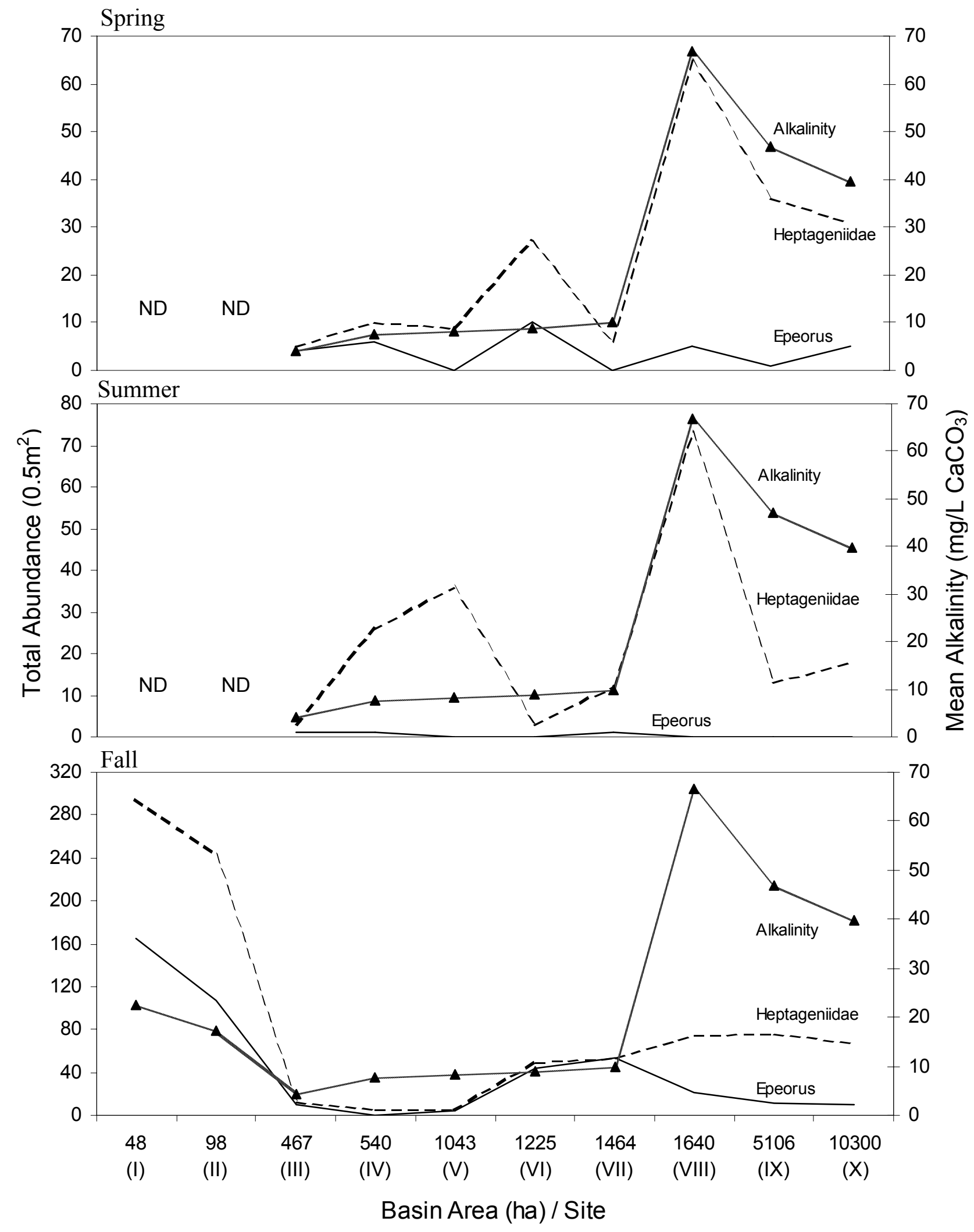

Figure 15. Abundance of Epeorus spp. to Heptageniidae along a $25.2 \mathrm{~km}$ continuum of the Upper Shavers Fork, WV, May - October 2000. (ND = no data. Sites I-II data collected and presented for fall season only.) 
Appendices. 
Appendix I. Macroinvertebrate Orders and Families collected along a $25.2 \mathrm{~km}$ continuum of the Upper Shavers Fork, WV, May - October, 2000.

\begin{tabular}{|c|c|c|c|}
\hline Order & Family & Order & Family \\
\hline Amphipoda & Gammaridae & Megaloptera & $\begin{array}{c}\text { Corydalidae } \\
\text { Sialidae }\end{array}$ \\
\hline Coleoptera & $\begin{array}{c}\text { Elmidae } \\
\text { Hydrophilidae } \\
\text { Psephenidae }\end{array}$ & Odonata & $\begin{array}{l}\text { Aeshnidae } \\
\text { Gomphidae }\end{array}$ \\
\hline Diptera & $\begin{array}{c}\text { Athericidae } \\
\text { Blepharicidae } \\
\text { Ceratopogonidae } \\
\text { Chironomidae } \\
\text { Dixidae } \\
\text { Empididae } \\
\text { Muscidae } \\
\text { Simulidae } \\
\text { Tabanidae } \\
\text { Tipulidae }\end{array}$ & Plecoptera & $\begin{array}{c}\text { Capniidae } \\
\text { Chloroperlidae } \\
\text { Leuctridae } \\
\text { Nemouridae } \\
\text { Peltoperlidae } \\
\text { Perlidae } \\
\text { Perlodidae } \\
\text { Pteronarcyidae } \\
\text { Taenioptyrigidae }\end{array}$ \\
\hline Ephemeroptera & $\begin{array}{l}\text { Ameletidae } \\
\text { Baetiscidae } \\
\text { Baetidae } \\
\text { Caenidae } \\
\text { Ephemerellidae } \\
\text { Ephemeridae } \\
\text { Heptageniidae } \\
\text { Isonychiidae } \\
\text { Leptophlebiidae } \\
\text { Siphlonuridae }\end{array}$ & Trichoptera & $\begin{array}{c}\text { Brachycentridae } \\
\text { Glossosomatidae } \\
\text { Hydropsychidae } \\
\text { Hydroptilidae } \\
\text { Lepidostomatidae } \\
\text { Leptoceridae } \\
\text { Limnephilidae } \\
\text { Odontoceridae } \\
\text { Polycentropodidae } \\
\text { Philopotamidae } \\
\text { Psychomyiidae } \\
\text { Rhyacophilidae } \\
\text { Uenoidae }\end{array}$ \\
\hline
\end{tabular}


Appendix II. Contribution of individual families to feeding group biomass in theUpper Shavers Fork, WV, May - October 2000. (Families contributing $\geq 0.5 \%$ of biomass are listed.)

Spring Shredder Functional Group

\begin{tabular}{|c|c|c|c|c|c|c|c|c|}
\hline \multicolumn{4}{|c|}{ Site Description } & \multicolumn{4}{|c|}{ FFG Family and Characteristics } & \multirow{2}{*}{$\begin{array}{l}\text { Total } \\
\text { Family } \\
\text { Richness }\end{array}$} \\
\hline B.A. & C.C. & Alk. & $\mathrm{pH}$ & Shredder & $\%$ & $\mathrm{mgDM} / \mathrm{m}^{2}$ & $\mathrm{n}$ & \\
\hline 48 & 31 & 22.4 & 5.5 & ND & ND & ND & ND & ND \\
\hline 98 & 92 & 17.2 & 6.1 & ND & ND & ND & ND & ND \\
\hline \multirow[t]{3}{*}{469} & 92 & 4.2 & 4.5 & Leuctridae & 88 & 17.6 & 352 & 06 \\
\hline & & & & Nemouridae & 06 & 1.1 & 03 & \\
\hline & & & & Lepidostomatidae & 05 & 1.1 & 02 & \\
\hline \multirow[t]{4}{*}{540} & 92 & 7.6 & 4.5 & Leuctridae & 89 & 7.7 & 106 & 06 \\
\hline & & & & Lepidostomatidae & 05 & 0.6 & 02 & \\
\hline & & & & Peltoperlidae & 03 & 0.3 & 20 & \\
\hline & & & & Capniidae & 02 & 0.1 & 15 & \\
\hline \multirow[t]{4}{*}{1043} & 84 & 8.3 & 5.8 & Leuctridae & 62 & 7.4 & 129 & 05 \\
\hline & & & & Limnephilidae & 19 & 2.3 & 03 & \\
\hline & & & & Lepidostomatidae & 15 & 1.8 & 04 & \\
\hline & & & & Capniidae & 04 & 0.5 & 71 & \\
\hline \multirow[t]{2}{*}{1225} & 54 & 8.9 & 5.7 & Leuctridae & 89 & 3.9 & 111 & 04 \\
\hline & & & & Capniidae & 10 & 0.4 & 60 & \\
\hline \multirow[t]{3}{*}{1464} & 74 & 10.0 & 6.0 & Leuctridae & 97 & 2.2 & 88 & 03 \\
\hline & & & & Capniidae & 02 & 0.1 & 10 & \\
\hline & & & & Gammaridae & 01 & 0.02 & 20 & \\
\hline \multirow[t]{2}{*}{1640} & 44 & 66.7 & 6.4 & Leuctridae & 99 & 53.2 & 751 & 04 \\
\hline & & & & Capniidae & 01 & 0.5 & 07 & \\
\hline \multirow[t]{3}{*}{5106} & 21 & 47.0 & 6.6 & Leuctridae & 97 & 4.2 & 203 & 03 \\
\hline & & & & Nemouridae & 02 & 0.1 & 07 & \\
\hline & & & & Capniidae & 01 & 0.1 & 06 & \\
\hline \multirow[t]{5}{*}{10300} & 07 & 39.7 & 6.2 & Leuctridae & 71 & 2.1 & 91 & 05 \\
\hline & & & & Capniidae & 12 & 0.4 & 10 & \\
\hline & & & & Nemouridae & 08 & 0.2 & 05 & \\
\hline & & & & Pteronarcyidae & 07 & 0.2 & 01 & \\
\hline & & & & Taenoptyrigidae & 01 & 0.1 & 04 & \\
\hline
\end{tabular}

B.A. $=$ Basin Area (ha). C.C. $=$ Mean $(\mathrm{n}=10)$ Canopy Cover (\%).

Alk. $=$ Mean $(\mathrm{n}=4-6)$ Alkalinity $\left(\mathrm{mg} / \mathrm{L} \mathrm{CaCO}_{3}\right) \cdot \mathrm{pH}=$ Minimum $(\mathrm{n}=10) \mathrm{pH}$. 
Summer Shredder Functional Group

\begin{tabular}{|c|c|c|c|c|c|c|c|c|}
\hline \multicolumn{4}{|c|}{ Site Description } & \multicolumn{4}{|c|}{ FFG Family and Characteristics } & \multirow{2}{*}{$\begin{array}{l}\text { Total } \\
\text { Family } \\
\text { Richness }\end{array}$} \\
\hline B.A. & C.C. & Alk. & $\mathrm{PH}$ & Shredder & $\%$ & $\mathrm{mgDM} / \mathrm{m}^{2}$ & $\mathrm{n}$ & \\
\hline 48 & 31 & 22.4 & 5.5 & ND & ND & ND & ND & ND \\
\hline 98 & 92 & 17.2 & 6.1 & ND & ND & ND & ND & ND \\
\hline \multirow{3}{*}{469} & 92 & 4.2 & 4.5 & Leuctridae & 68 & 8.4 & 365 & 04 \\
\hline & & & & Capniidae & 30 & 3.8 & 258 & \\
\hline & & & & Lepidostomatidae & 02 & 0.2 & 01 & \\
\hline \multirow[t]{3}{*}{540} & 92 & 7.6 & 4.5 & Leuctridae & 90 & 11.8 & 264 & 06 \\
\hline & & & & Capniidae & 08 & 1.0 & 34 & \\
\hline & & & & Peltoperlidae & 01 & 0.2 & 01 & \\
\hline 1043 & 84 & 8.3 & 5.8 & Leuctridae & 99 & 12.5 & 221 & 02 \\
\hline 1225 & 54 & 8.9 & 5.7 & Leuctridae & 99 & 25.1 & 237 & 02 \\
\hline \multirow[t]{2}{*}{1464} & 74 & 10.0 & 6.0 & Leuctridae & 95 & 3.1 & 47 & 03 \\
\hline & & & & Capniidae & 05 & 0.2 & 10 & \\
\hline \multirow[t]{2}{*}{1640} & 44 & 66.7 & 6.4 & Leuctridae & 97 & 7.3 & 82 & 03 \\
\hline & & & & Capniidae & 03 & 0.2 & 15 & \\
\hline \multirow[t]{2}{*}{5106} & 21 & 47.0 & 6.6 & Leuctridae & 94 & 3.7 & 41 & 02 \\
\hline & & & & Limnephilidae & 06 & 0.2 & 05 & \\
\hline \multirow[t]{3}{*}{10300} & 07 & 39.7 & 6.2 & Pteronarcyidae & 84 & 14.0 & 03 & 04 \\
\hline & & & & Leuctridae & 13 & 2.1 & 24 & \\
\hline & & & & Lepidostomatidae & 03 & 0.5 & 01 & \\
\hline
\end{tabular}

B.A. $=$ Basin Area (ha). C.C. $=$ Mean $(\mathrm{n}=10)$ Canopy Cover $(\%)$.

Alk. $=$ Mean $(\mathrm{n}=4-6)$ Alkalinity $\left(\mathrm{mg} / \mathrm{L} \mathrm{CaCO}_{3}\right) . \mathrm{pH}=\operatorname{Minimum}(\mathrm{n}=10) \mathrm{pH}$. 


\begin{tabular}{|c|c|c|c|c|c|c|c|c|}
\hline \multicolumn{4}{|c|}{ Site Description } & \multicolumn{3}{|c|}{ FFG Family and Characteristics } & \multirow{2}{*}{\multicolumn{2}{|c|}{$\begin{array}{l}\text { Total } \\
\text { Family } \\
\text { Richness }\end{array}$}} \\
\hline B.A. & C.C. & Alk. & $\mathrm{pH}$ & Shredder & $\%$ & $\mathrm{mgDM} / \mathrm{m}^{2}$ & & \\
\hline \multirow[t]{3}{*}{48} & 31 & 22.4 & 5.5 & Leuctridae & 65 & 8.9 & 248 & 05 \\
\hline & & & & Capniidae & 34 & 4.6 & 44 & \\
\hline & & & & Gammaridae & 01 & 0.1 & 39 & \\
\hline \multirow[t]{4}{*}{98} & 92 & 17.2 & 6.1 & Pteronarcyidae & 62 & 29.0 & 01 & 05 \\
\hline & & & & Leuctridae & 28 & 13.2 & 204 & \\
\hline & & & & Nemouridae & 07 & 3.3 & 36 & \\
\hline & & & & Capniidae & 03 & 1.2 & 06 & \\
\hline \multirow[t]{4}{*}{469} & 92 & 4.2 & 4.5 & Leuctridae & 47 & 9.0 & 216 & 06 \\
\hline & & & & Capniidae & 42 & 8.0 & 109 & \\
\hline & & & & Taenioptyrigidae & 10 & 1.9 & 17 & \\
\hline & & & & Nemouridae & 02 & 0.3 & 40 & \\
\hline \multirow[t]{4}{*}{540} & 92 & 7.6 & 4.5 & Capniidae & 30 & 3.9 & 85 & 07 \\
\hline & & & & Limnephilidae & 27 & 3.5 & 03 & \\
\hline & & & & Peltoperlidae & 25 & 3.2 & 02 & \\
\hline & & & & Leuctridae & 18 & 2.3 & 92 & \\
\hline \multirow[t]{3}{*}{1043} & 84 & 8.3 & 5.8 & Leuctridae & 69 & 2.5 & 52 & 05 \\
\hline & & & & Capniidae & 28 & 1.0 & 30 & \\
\hline & & & & Taenioptyrigidae & 02 & 0.1 & 01 & \\
\hline \multirow[t]{4}{*}{1225} & 54 & 8.9 & 5.7 & Peltoperlidae & 47 & 5.0 & 03 & 06 \\
\hline & & & & Leuctridae & 28 & 3.0 & 76 & \\
\hline & & & & Capniidae & 18 & 1.9 & 49 & \\
\hline & & & & Lepidostomatidae & 07 & 0.7 & 01 & \\
\hline \multirow[t]{4}{*}{1464} & 74 & 10.0 & 6.0 & Leuctridae & 43 & 2.4 & 83 & 06 \\
\hline & & & & Peltoperlidae & 33 & 1.8 & 01 & \\
\hline & & & & Capniidae & 22 & 1.2 & 62 & \\
\hline & & & & Lepidostomatidae & 01 & 0.1 & 01 & \\
\hline \multirow[t]{4}{*}{1640} & 44 & 66.7 & 6.4 & Leuctridae & 85 & 3.9 & 195 & 05 \\
\hline & & & & Capniidae & 08 & 0.4 & 04 & \\
\hline & & & & Taenioptyrigidae & 05 & 0.2 & 01 & \\
\hline & & & & Gammaridae & 02 & 0.1 & 66 & \\
\hline \multirow[t]{3}{*}{5106} & 21 & 47.0 & 6.6 & Pteronarcyidae & 82 & 15.6 & 01 & 05 \\
\hline & & & & Capniidae & 13 & 2.4 & 198 & \\
\hline & & & & Leuctridae & 05 & 0.9 & 81 & \\
\hline \multirow[t]{3}{*}{10300} & 07 & 39.7 & 6.2 & Pternarcyidae & 95 & 101.1 & 01 & 05 \\
\hline & & & & Limnephilidae & 04 & 4.3 & 02 & \\
\hline & & & & Capniidae & 01 & 0.1 & 20 & \\
\hline
\end{tabular}

B.A. $=$ Basin Area (ha). C.C. $=$ Mean $(\mathrm{n}=10)$ Canopy Cover $(\%)$.

Alk. $=$ Mean $(n=4-6)$ Alkalinity $\left(m g / \mathrm{L} \mathrm{CaCO}_{3}\right) \cdot \mathrm{pH}=\operatorname{Minimum}(\mathrm{n}=10) \mathrm{pH}$. 


\section{Site Description \\ FFG Family and Characteristics \\ Total}

Family

\begin{tabular}{|c|c|c|c|c|c|c|c|c|}
\hline B.A. & C.C. & Alk. & $\mathrm{PH}$ & Scraper & $\%$ & $\mathrm{mgDM} / \mathrm{m}^{2}$ & $\mathrm{n}$ & Richness \\
\hline 48 & 31 & 22.4 & 5.5 & ND & ND & ND & ND & ND \\
\hline 98 & 92 & 17.2 & 6.1 & ND & ND & ND & ND & ND \\
\hline 469 & 92 & 4.2 & 4.5 & Heptageniidae & 99 & 14.6 & 05 & 02 \\
\hline 540 & 92 & 7.6 & 4.5 & Heptageniidae & 99 & 6.6 & 10 & 02 \\
\hline \multirow[t]{5}{*}{1043} & 84 & 8.3 & 5.8 & Heptageniidae & 36 & 1.4 & 09 & 05 \\
\hline & & & & Ameletidae & 29 & 1.1 & 01 & \\
\hline & & & & Glossosomatidae & 23 & 0.9 & 05 & \\
\hline & & & & Uenoidae & 10 & 0.4 & 10 & \\
\hline & & & & Elmidae & 01 & 0.03 & 08 & \\
\hline \multirow[t]{4}{*}{1225} & 54 & 8.9 & 5.7 & Heptageniidae & 83 & 29.2 & 27 & 06 \\
\hline & & & & Ameletidae & 12 & 4.2 & 05 & \\
\hline & & & & Brachycentridae & 02 & 0.9 & 01 & \\
\hline & & & & Hydrophilidae & 02 & 0.8 & 10 & \\
\hline \multirow[t]{2}{*}{1464} & 74 & 10.0 & 6.0 & Heptageniidae & 92 & 22.5 & 06 & 03 \\
\hline & & & & Ameletidae & 08 & 1.8 & 01 & \\
\hline \multirow[t]{3}{*}{1640} & 44 & 66.7 & 6.4 & Heptaganiidae & 69 & 10.5 & 65 & 03 \\
\hline & & & & Ameletidae & 30 & 4.7 & 02 & \\
\hline & & & & Elmidae & 01 & 0.1 & 13 & \\
\hline \multirow[t]{4}{*}{5106} & 21 & 47.0 & 6.6 & Heptageniidae & 93 & 26.0 & 36 & 05 \\
\hline & & & & Blepharicidae & 04 & 1.1 & 53 & \\
\hline & & & & Elmidae & 01 & 0.4 & 16 & \\
\hline & & & & Glossomatidae & 01 & 0.4 & 02 & \\
\hline \multirow[t]{7}{*}{10300} & 07 & 39.7 & 6.2 & Heptageniidae & 73 & 13.8 & 31 & 09 \\
\hline & & & & Ameletidae & 13 & 2.4 & 05 & \\
\hline & & & & Brachycentridae & 06 & 1.1 & 01 & \\
\hline & & & & Psychomiidae & 04 & 0.8 & 01 & \\
\hline & & & & Elmidae & 02 & 0.3 & 23 & \\
\hline & & & & Psephenidae & 01 & 0.2 & 01 & \\
\hline & & & & Blepharicidae & 01 & 0.2 & 18 & \\
\hline
\end{tabular}

B.A. $=$ Basin Area (ha). C.C. $=$ Mean $(n=10)$ Canopy Cover $(\%)$.

Alk. $=$ Mean $(\mathrm{n}=4-6)$ Alkalinity $\left(\mathrm{mg} / \mathrm{L} \mathrm{CaCO}_{3}\right) . \mathrm{pH}=\operatorname{Minimum}(\mathrm{n}=10) \mathrm{pH}$. 
Summer Scraper Functional Group

\begin{tabular}{|c|c|c|c|c|c|c|c|c|}
\hline \multicolumn{4}{|c|}{ Site Description } & \multicolumn{3}{|c|}{ FFG Family and Characteristics } & \multirow{2}{*}{\multicolumn{2}{|c|}{$\begin{array}{l}\text { Total } \\
\text { Family } \\
\text { Richness }\end{array}$}} \\
\hline B.A. & C.C. & Alk. & $\mathrm{pH}$ & Scraper & $\%$ & $\mathrm{mgDM} / \mathrm{m}^{2}$ & & \\
\hline 48 & 31 & 22.4 & 5.5 & ND & ND & ND & ND & ND \\
\hline 98 & 92 & 17.2 & 6.1 & ND & ND & ND & ND & ND \\
\hline \multirow[t]{2}{*}{469} & 92 & 4.2 & 4.5 & Heptageniidae & 50 & 4.2 & 03 & 03 \\
\hline & & & & Ameletidae & 49 & 4.1 & 03 & \\
\hline 540 & 92 & 7.6 & 4.5 & Heptageniidae & 99 & 11.0 & 26 & 03 \\
\hline \multirow[t]{2}{*}{1043} & 84 & 8.3 & 5.8 & Heptageniidae & 99 & 7.2 & 36 & 04 \\
\hline & & & & Uenoidae & 01 & 0.1 & 05 & \\
\hline \multirow[t]{3}{*}{1225} & 54 & 8.9 & 5.7 & Heptageniidae & 53 & 3.4 & 03 & 03 \\
\hline & & & & Elmidae & 32 & 2.1 & 52 & \\
\hline & & & & Ameletidae & 15 & 1.0 & 01 & \\
\hline \multirow[t]{5}{*}{1464} & 74 & 10.0 & 6.0 & Heptageniidae & 75 & 1.6 & 12 & 07 \\
\hline & & & & Hydrophilidae & 10 & 0.2 & 10 & \\
\hline & & & & Elmidae & 12 & 0.2 & 118 & \\
\hline & & & & Glossomatidae & 03 & 0.1 & 02 & \\
\hline & & & & Ameletidae & 01 & 0.03 & 01 & \\
\hline \multirow[t]{4}{*}{1640} & 44 & 66.7 & 6.4 & Heptageniidae & 93 & 31.9 & 73 & 05 \\
\hline & & & & Psephenidae & 03 & 1.2 & 01 & \\
\hline & & & & Uenoidae & 03 & 0.9 & 15 & \\
\hline & & & & Elmidae & 01 & 0.3 & 23 & \\
\hline \multirow[t]{4}{*}{5106} & 21 & 47.0 & 6.6 & Psephenidae & 50 & 2.8 & 05 & 04 \\
\hline & & & & Heptageniidae & 46 & 2.6 & 13 & \\
\hline & & & & Elmidae & 03 & 0.1 & 24 & \\
\hline & & & & Blepharicidae & 01 & 0.04 & 09 & \\
\hline \multirow[t]{3}{*}{10300} & 07 & 39.7 & 6.2 & Odontoceridae & 61 & 7.2 & 02 & 05 \\
\hline & & & & Heptageniidae & 33 & 3.9 & 18 & \\
\hline & & & & Elmidae & 07 & 0.8 & 42 & \\
\hline
\end{tabular}

B.A. $=$ Basin Area (ha). C.C. $=$ Mean $(\mathrm{n}=10)$ Canopy Cover $(\%)$.

Alk. $=$ Mean $(\mathrm{n}=4-6)$ Alkalinity $\left(\mathrm{mg} / \mathrm{L} \mathrm{CaCO}_{3}\right) \cdot \mathrm{pH}=$ Minimum $(\mathrm{n}=10) \mathrm{pH}$. 


\begin{tabular}{|c|c|c|c|c|c|c|c|c|}
\hline \multicolumn{4}{|c|}{ Site Description } & \multicolumn{3}{|c|}{ FFG Family and Characteristics } & \multirow{2}{*}{\multicolumn{2}{|c|}{$\begin{array}{ll} & \text { Total } \\
& \text { Family } \\
\text { n } & \text { Richness } \\
\end{array}$}} \\
\hline B.A. & C.C. & Alk. & $\mathrm{pH}$ & Scraper & $\%$ & $\mathrm{mgDM} / \mathrm{m}^{2}$ & & \\
\hline \multirow[t]{4}{*}{48} & 31 & 22.4 & 5.5 & Heptageniidae & 87 & 24.4 & 295 & 04 \\
\hline & & & & Glossosmatidae & 05 & 1.5 & 01 & \\
\hline & & & & Ameletidae & 04 & 1.2 & 06 & \\
\hline & & & & Elmidae & 03 & 1.1 & 34 & \\
\hline \multirow[t]{3}{*}{98} & 92 & 17.2 & 6.1 & Psychomyiidae & 56 & 8.3 & 03 & 04 \\
\hline & & & & Heptageniidae & 41 & 6.1 & 243 & \\
\hline & & & & Ameletidae & 03 & 0.4 & 04 & \\
\hline \multirow[t]{4}{*}{469} & 92 & 4.2 & 4.5 & Heptageniidae & 59 & 12.0 & 12 & 05 \\
\hline & & & & Ameletidae & 28 & 5.8 & 12 & \\
\hline & & & & Psychomyiidae & 12 & 2.4 & 04 & \\
\hline & & & & Hydroptilidae & 01 & 0.1 & 02 & \\
\hline \multirow[t]{3}{*}{540} & 92 & 7.6 & 4.5 & Elmidae & 59 & 0.04 & 03 & 03 \\
\hline & & & & Psychomyiidae & 24 & 0.02 & 01 & \\
\hline & & & & Heptageniidae & 17 & 0.01 & 05 & \\
\hline \multirow[t]{5}{*}{1043} & 84 & 8.3 & 5.8 & Heptageniidae & 79 & 2.7 & 06 & 05 \\
\hline & & & & Psychomyiidae & 14 & 0.5 & 03 & \\
\hline & & & & Glossosomatidae & 03 & 0.1 & 06 & \\
\hline & & & & Ameletidae & 03 & 0.1 & 01 & \\
\hline & & & & Elmidae & 01 & 0.04 & 14 & \\
\hline \multirow[t]{3}{*}{1225} & 54 & 8.9 & 5.7 & Heptageniidae & 97 & 18.0 & 50 & 03 \\
\hline & & & & Elmidae & 02 & 0.3 & 39 & \\
\hline & & & & Glossosomatidae & 01 & 0.2 & 01 & \\
\hline \multirow[t]{5}{*}{1464} & 74 & 10.0 & 6.0 & Heptageniidae & 49 & 0.6 & 53 & 05 \\
\hline & & & & Psychomyiidae & 21 & 0.3 & 06 & \\
\hline & & & & Hydrophilidae & 15 & 0.2 & 05 & \\
\hline & & & & Elmidae & 12 & 0.1 & 31 & \\
\hline & & & & Glossosomatidae & 03 & 0.03 & 05 & \\
\hline \multirow[t]{4}{*}{1640} & 44 & 66.7 & 6.4 & Heptageniidae & 86 & 42.8 & 75 & 05 \\
\hline & & & & Brachycentridae & 12 & 6.1 & 01 & \\
\hline & & & & Psephenidae & 01 & 0.4 & 03 & \\
\hline & & & & Uenoidae & 01 & 0.3 & 05 & \\
\hline \multirow[t]{4}{*}{5106} & 21 & 47.0 & 6.6 & Heptageniidae & 92 & 23.7 & 76 & 05 \\
\hline & & & & Hydroptilidae & 06 & 1.5 & 03 & \\
\hline & & & & Elmidae & 01 & 0.2 & 12 & \\
\hline & & & & Psephenidae & 01 & 0.2 & 02 & \\
\hline \multirow[t]{4}{*}{10300} & 07 & 39.7 & 6.2 & Heptageniidae & 90 & 39.8 & 68 & 05 \\
\hline & & & & Odontoceridae & 08 & 3.6 & 01 & \\
\hline & & & & Glossosomatidae & 01 & 0.4 & 01 & \\
\hline & & & & Elmidae & 01 & 0.3 & 31 & \\
\hline
\end{tabular}

B.A. $=$ Basin Area (ha). C.C. $=$ Mean $(\mathrm{n}=10)$ Canopy Cover (\%).

Alk. $=$ Mean $(\mathrm{n}=4-6)$ Alkalinity $\left(\mathrm{mg} / \mathrm{L} \mathrm{CaCO}_{3}\right) . \mathrm{pH}=\operatorname{Minimum}(\mathrm{n}=10) \mathrm{pH}$. 


\begin{tabular}{|c|c|c|c|c|c|c|c|c|}
\hline \multicolumn{4}{|c|}{ Site Description } & \multicolumn{4}{|c|}{ FFG Family and Characteristics } & \multirow{2}{*}{$\begin{array}{l}\text { Total } \\
\text { Family } \\
\text { Richness }\end{array}$} \\
\hline B.A. & C.C. & Alk. & $\mathrm{pH}$ & Gatherer & $\%$ & $\mathrm{mgDM} / \mathrm{m}^{2}$ & $\mathrm{n}$ & \\
\hline 48 & 31 & 22.4 & 5.5 & ND & ND & ND & ND & ND \\
\hline 98 & 92 & 17.2 & 6.1 & ND & ND & ND & ND & ND \\
\hline \multirow[t]{3}{*}{469} & 92 & 4.2 & 4.5 & Chironomidae & 60 & 9.3 & 282 & 04 \\
\hline & & & & Ephemerellidae & 39 & 6.1 & 16 & \\
\hline & & & & Tipulidae & 01 & 0.2 & 08 & \\
\hline \multirow[t]{3}{*}{540} & 92 & 7.6 & 4.5 & Chironomidae & 90 & 12.4 & 507 & 04 \\
\hline & & & & Ephemerellidae & 09 & 1.2 & 02 & \\
\hline & & & & Tipulidae & 01 & 0.1 & 04 & \\
\hline \multirow[t]{2}{*}{1043} & 84 & 8.3 & 5.8 & Chironomidae & 96 & 10.3 & 396 & 05 \\
\hline & & & & Tipulidae & 03 & 0.3 & 01 & \\
\hline \multirow[t]{2}{*}{1225} & 54 & 8.9 & 5.7 & Chironomidae & 73 & 12.9 & 618 & 03 \\
\hline & & & & Tipulidae & 27 & 4.7 & 21 & \\
\hline \multirow[t]{5}{*}{1464} & 74 & 10.0 & 6.0 & Tipulidae & 53 & 11.3 & 11 & 07 \\
\hline & & & & Chironomidae & 35 & 7.5 & 568 & \\
\hline & & & & Ephemeridae & 09 & 1.9 & 01 & \\
\hline & & & & Ephemerellidae & 02 & 0.5 & 19 & \\
\hline & & & & Baetidae & 01 & 0.1 & 15 & \\
\hline \multirow[t]{6}{*}{1640} & 44 & 66.7 & 6.4 & Ephemeridae & 37 & 49.8 & 15 & 07 \\
\hline & & & & Chironomidae & 23 & 31.3 & 946 & \\
\hline & & & & Ephemerellidae & 18 & 23.5 & 46 & \\
\hline & & & & Leptophlebiidae & 10 & 13.9 & 160 & \\
\hline & & & & Tipulidae & 06 & 8.5 & 97 & \\
\hline & & & & Baetidae & 05 & 6.9 & 17 & \\
\hline \multirow[t]{6}{*}{5106} & 21 & 47.0 & 6.6 & Chironomidae & 35 & 25.2 & 1007 & 07 \\
\hline & & & & Tipulidae & 26 & 18.4 & 04 & \\
\hline & & & & Leptophlebiidae & 23 & 16.5 & 313 & \\
\hline & & & & Ephemeridae & 13 & 9.1 & 36 & \\
\hline & & & & Baetidae & 02 & 1.5 & 20 & \\
\hline & & & & Ephemerellidae & 02 & 1.1 & 16 & \\
\hline \multirow[t]{7}{*}{10300} & 07 & 39.7 & 6.2 & Chironomidae & 52 & 21.3 & 735 & 07 \\
\hline & & & & Leptophlebiidae & 16 & 6.5 & 189 & \\
\hline & & & & Ephemerellidae & 16 & 6.5 & 09 & \\
\hline & & & & Baetidae & 06 & 2.5 & 16 & \\
\hline & & & & Tipulidade & 06 & 2.3 & 49 & \\
\hline & & & & Ephemeridae & 04 & 1.6 & 03 & \\
\hline & & & & Siphlonuridae & 01 & 0.2 & 28 & \\
\hline
\end{tabular}

B.A. $=$ Basin Area (ha). C.C. $=$ Mean $(\mathrm{n}=10)$ Canopy Cover (\%).

Alk. $=$ Mean $(\mathrm{n}=4-6)$ Alkalinity $\left(\mathrm{mg} / \mathrm{L} \mathrm{CaCO}_{3}\right) \cdot \mathrm{pH}=$ Minimum $(\mathrm{n}=10) \mathrm{pH}$. 


\begin{tabular}{|c|c|c|c|c|c|c|c|c|}
\hline \multicolumn{4}{|c|}{ Site Description } & \multicolumn{4}{|c|}{ FFG Family and Characteristics } & \multirow{2}{*}{$\begin{array}{l}\text { Total } \\
\text { Family } \\
\text { Richness }\end{array}$} \\
\hline B.A. & C.C. & Alk. & $\mathrm{PH}$ & Gatherer & $\%$ & $\mathrm{mgDM} / \mathrm{m}^{2}$ & $\mathrm{n}$ & \\
\hline 48 & 31 & 22.4 & 5.5 & ND & ND & $\mathrm{ND}$ & ND & ND \\
\hline 98 & 92 & 17.2 & 6.1 & ND & ND & ND & ND & ND \\
\hline \multirow[t]{4}{*}{469} & 92 & 4.2 & 4.5 & Chironomidae & 47 & 21.7 & 749 & 04 \\
\hline & & & & Ephemerellidae & 46 & 20.9 & 17 & \\
\hline & & & & Baetidae & 05 & 2.2 & 04 & \\
\hline & & & & Tipulidae & 03 & 1.2 & 23 & \\
\hline \multirow[t]{4}{*}{540} & 92 & 7.6 & 4.5 & Chironomidae & 79 & 12.3 & 643 & 04 \\
\hline & & & & Baetidae & 12 & 1.9 & 05 & \\
\hline & & & & Ephemerellidae & 08 & 1.3 & 01 & \\
\hline & & & & Tipulidae & 01 & 0.2 & 14 & \\
\hline \multirow[t]{6}{*}{1043} & 84 & 8.3 & 5.8 & Chironomidae & 73 & 14.8 & 515 & 06 \\
\hline & & & & Baetidae & 21 & 4.1 & 23 & \\
\hline & & & & Caenidae & 04 & 0.7 & 02 & \\
\hline & & & & Ephemerellidae & 01 & 0.2 & 05 & \\
\hline & & & & Tipulidae & 01 & 0.2 & 05 & \\
\hline & & & & Siphlonuridae & 01 & 0.3 & 25 & \\
\hline \multirow{3}{*}{1225} & 54 & 8.9 & 5.7 & Chironomidae & 87 & 31.7 & 1081 & 05 \\
\hline & & & & Baetidae & 12 & 4.4 & 13 & \\
\hline & & & & Leptophlebiidae & 01 & 0.2 & 07 & \\
\hline \multirow[t]{7}{*}{1464} & 74 & 10.0 & 6.0 & Chironomidae & 75 & 8.5 & 718 & 07 \\
\hline & & & & Ephemerellidae & 07 & 0.8 & 04 & \\
\hline & & & & Baetiscidae & 07 & 0.7 & 02 & \\
\hline & & & & Baetidae & 06 & 0.6 & 13 & \\
\hline & & & & Leptophlebiidae & 03 & 0.3 & 72 & \\
\hline & & & & Tipulidae & 02 & 0.2 & 14 & \\
\hline & & & & Siphlonuridae & 01 & 0.03 & 08 & \\
\hline \multirow[t]{6}{*}{1640} & 44 & 66.7 & 6.4 & Ephemeridae & 36 & 65.9 & 21 & 09 \\
\hline & & & & Caenidae & 30 & 56.8 & 226 & \\
\hline & & & & Chironomidae & 25 & 46.6 & 1263 & \\
\hline & & & & Leptophlebiidae & 07 & 13.4 & 389 & \\
\hline & & & & Baetidae & 01 & 2.4 & 23 & \\
\hline & & & & Tipulidae & 01 & 1.2 & 75 & \\
\hline \multirow[t]{7}{*}{5106} & 21 & 47.0 & 6.6 & Chironomidae & 64 & 21.5 & 1574 & 09 \\
\hline & & & & Baetidae & 11 & 3.8 & 63 & \\
\hline & & & & Leptophlebiidae & 10 & 3.3 & 127 & \\
\hline & & & & Tipulidae & 10 & 3.2 & 53 & \\
\hline & & & & Caenidae & 03 & 0.9 & 32 & \\
\hline & & & & Ephemerellidae & 02 & 0.7 & 27 & \\
\hline & & & & Siphlonuridae & 01 & 0.2 & 21 & \\
\hline \multirow[t]{8}{*}{10300} & 07 & 39.7 & 6.2 & Chironomidae & 39 & 10.2 & 744 & 09 \\
\hline & & & & Ephemeridae & 19 & 5.0 & 03 & \\
\hline & & & & Baetidae & 18 & 4.7 & 27 & \\
\hline & & & & Leptophlebiidae & 08 & 2.13 & 88 & \\
\hline & & & & Tipulidae & 07 & 1.9 & 82 & \\
\hline & & & & Ephemerellidae & 04 & 1.0 & 19 & \\
\hline & & & & Baetiscidae & 03 & 0.8 & 01 & \\
\hline & & & & Caenidae & 03 & 0.8 & 02 & \\
\hline
\end{tabular}

B.A. $=$ Basin Area (ha). C.C. $=$ Mean $(\mathrm{n}=10)$ Canopy Cover $(\%)$.

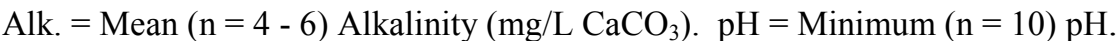




\begin{tabular}{|c|c|c|c|c|c|c|c|c|}
\hline \multicolumn{4}{|c|}{ Site Description } & \multicolumn{4}{|c|}{ FFG Family and Characteristics } & \multirow{2}{*}{$\begin{array}{l}\text { Total } \\
\text { Family } \\
\text { Richness }\end{array}$} \\
\hline B.A. & C.C. & Alk. & $\mathrm{pH}$ & Gatherer & $\%$ & $\mathrm{mgDM} / \mathrm{m}^{2}$ & $\mathrm{n}$ & \\
\hline \multirow[t]{5}{*}{48} & 31 & 22.4 & 5.5 & Ephemerellidae & 59 & 64.7 & 121 & 05 \\
\hline & & & & Tipulidae & 16 & 17.7 & 78 & \\
\hline & & & & Baetidae & 16 & 17.5 & 186 & \\
\hline & & & & Leptophlebiidae & 05 & 5.9 & 158 & \\
\hline & & & & Chironomidae & 04 & 4.0 & 283 & \\
\hline \multirow[t]{5}{*}{98} & 92 & 17.2 & 6.1 & Chironomidae & 32 & 9.3 & 535 & 06 \\
\hline & & & & Baetidae & 25 & 7.2 & 138 & \\
\hline & & & & Ephemerellidae & 23 & 6.7 & 09 & \\
\hline & & & & Tipulidae & 16 & 4.7 & 20 & \\
\hline & & & & Leptophlebiidae & 04 & 1.2 & 125 & \\
\hline \multirow[t]{4}{*}{469} & 92 & 4.2 & 4.5 & Ephemerellidae & 82 & 26.1 & 17 & 05 \\
\hline & & & & Chironomidae & 16 & 5.2 & 598 & \\
\hline & & & & Baetidae & 01 & 0.3 & 35 & \\
\hline & & & & Tipulidae & 01 & 0.3 & 11 & \\
\hline \multirow[t]{6}{*}{540} & 92 & 7.6 & 4.5 & Chironomidae & 74 & 2.1 & 284 & 06 \\
\hline & & & & Ephemerellidae & 13 & 0.4 & 01 & \\
\hline & & & & Tipulidae & 04 & 0.1 & 09 & \\
\hline & & & & Baetidae & 04 & 0.2 & 08 & \\
\hline & & & & Leptophlebiidae & 03 & 0.1 & 05 & \\
\hline & & & & Siphlonuridae & 01 & $<0.01$ & 10 & \\
\hline \multirow[t]{5}{*}{1043} & 84 & 8.3 & 5.8 & Chironomidae & 45 & 3.2 & 367 & 05 \\
\hline & & & & Baetidae & 24 & 1.7 & 190 & \\
\hline & & & & Siphlonuridae & 17 & 1.2 & 52 & \\
\hline & & & & Ephemerellidae & 08 & 0.6 & 07 & \\
\hline & & & & Tipulidae & 06 & 0.4 & 06 & \\
\hline \multirow[t]{4}{*}{1225} & 54 & 8.9 & 5.7 & Chironomidae & 46 & 7.8 & 633 & 05 \\
\hline & & & & Baetidae & 32 & 4.2 & 442 & \\
\hline & & & & Siphlonuridae & 21 & 3.5 & 196 & \\
\hline & & & & Leptophlebiidae & 01 & 0.1 & 10 & \\
\hline \multirow[t]{6}{*}{1464} & 74 & 10.0 & 6.0 & Tipulidae & 45 & 17.7 & 21 & 06 \\
\hline & & & & Baetidae & 18 & 6.9 & 551 & \\
\hline & & & & Siphlonuridae & 11 & 4.1 & 414 & \\
\hline & & & & Chironomidae & 09 & 3.6 & 362 & \\
\hline & & & & Leptophlebiidae & 09 & 3.6 & 126 & \\
\hline & & & & Ephemerellidae & 08 & 3.2 & 17 & \\
\hline \multirow[t]{7}{*}{1640} & 44 & 66.7 & 6.4 & Leptophlebiidae & 42 & 88.2 & 301 & 09 \\
\hline & & & & Chironomidae & 23 & 49.5 & 2761 & \\
\hline & & & & Ephemeridae & 12 & 24.4 & 12 & \\
\hline & & & & Baetiscidae & 09 & 18.5 & 02 & \\
\hline & & & & Ephemerellidae & 07 & 13.9 & 197 & \\
\hline & & & & Tipulidae & 05 & 9.7 & 141 & \\
\hline & & & & Baetidae & 04 & 7.7 & 200 & \\
\hline \multirow[t]{6}{*}{5106} & 21 & 47.0 & 6.6 & Leptophlebiidae & 37 & 40.0 & 957 & 09 \\
\hline & & & & Chironomidae & 26 & 28.0 & 2086 & \\
\hline & & & & Ephemerellidae & 16 & 16.7 & 57 & \\
\hline & & & & Baetiscidae & 11 & 11.8 & 03 & \\
\hline & & & & Tipulidae & 09 & 10.0 & 169 & \\
\hline & & & & Baetidae & 01 & 0.9 & 33 & \\
\hline
\end{tabular}


Fall Gatherer Functional Group continued. Site Description FFG Family and Characteristics

Total

Family

B.A. C.C. Alk. $\mathrm{pH}$ Gatherer $\% \quad \mathrm{mgDM} / \mathrm{m}^{2} \quad \mathrm{n}$ Richness

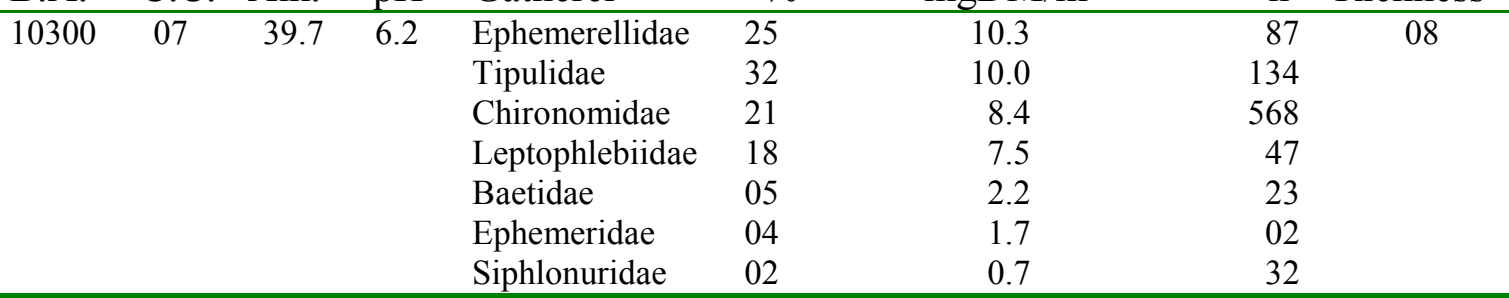

B.A. $=$ Basin Area (ha). C.C. $=$ Mean $(\mathrm{n}=10)$ Canopy Cover $(\%)$.

Alk. $=$ Mean $(\mathrm{n}=4-6)$ Alkalinity $\left(\mathrm{mg} / \mathrm{L} \mathrm{CaCO}_{3}\right) . \mathrm{pH}=\operatorname{Minimum}(\mathrm{n}=10) \mathrm{pH}$. 


\begin{tabular}{|c|c|c|c|c|c|c|c|c|}
\hline \multicolumn{4}{|c|}{ Site Description } & \multicolumn{3}{|c|}{ FFG Family and Characteristics } & \multirow{2}{*}{\multicolumn{2}{|c|}{$\begin{array}{l}\text { Total } \\
\text { Family } \\
\text { Richness }\end{array}$}} \\
\hline B.A. & C.C. & Alk. & $\mathrm{pH}$ & Filterer & $\%$ & $\mathrm{mgDM} / \mathrm{m}^{2}$ & & \\
\hline 48 & 31 & 22.4 & 5.5 & ND & ND & ND & ND & ND \\
\hline 98 & 92 & 17.2 & 6.1 & ND & ND & ND & ND & ND \\
\hline \multirow[t]{2}{*}{469} & 92 & 4.2 & 4.5 & Polycentropodidae & 94 & 3.5 & 11 & 02 \\
\hline & & & & Simulidae & 06 & 0.2 & 06 & \\
\hline 540 & 92 & 7.6 & 4.5 & Polycentropodidae & 100 & 1.3 & 14 & 01 \\
\hline 1043 & 84 & 8.3 & 5.8 & Polycentropodidae & 100 & 6.8 & 10 & 01 \\
\hline \multirow[t]{2}{*}{1225} & 54 & 8.9 & 5.7 & Hydropsychidae & 61 & 4.5 & 03 & 03 \\
\hline & & & & Polycentropodidae & 39 & 2.8 & 10 & \\
\hline 1464 & 74 & 10.0 & 6.0 & Polycentropodidae & 100 & 0.01 & 12 & 01 \\
\hline \multirow[t]{2}{*}{1640} & 44 & 66.7 & 6.4 & Polycentropodidae & 69 & 10.7 & 19 & 03 \\
\hline & & & & Hydropsychidae & 31 & 4.7 & 23 & \\
\hline \multirow[t]{3}{*}{5106} & 21 & 47.0 & 6.6 & Isonychiidae & 59 & 20.1 & 03 & 03 \\
\hline & & & & Hydropsychidae & 36 & 12.4 & 18 & \\
\hline & & & & Polycentropodidae & 05 & 1.8 & 21 & \\
\hline \multirow[t]{3}{*}{10300} & 07 & 39.7 & 6.2 & Polycentropodidae & 53 & 6.4 & 38 & 03 \\
\hline & & & & Hydropsychidae & 46 & 5.6 & 16 & \\
\hline & & & & Simulidae & 01 & 0.1 & 01 & \\
\hline
\end{tabular}

B.A. $=$ Basin Area (ha). C.C. $=$ Mean $(\mathrm{n}=10)$ Canopy Cover $(\%)$.

Alk. $=$ Mean $(n=4-6)$ Alkalinity $\left(\mathrm{mg} / \mathrm{L} \mathrm{CaCO}_{3}\right) . \mathrm{pH}=\operatorname{Minimum}(\mathrm{n}=10) \mathrm{pH}$. 
Summer Filterer Functional Group

\begin{tabular}{|c|c|c|c|c|c|c|c|c|}
\hline \multicolumn{4}{|c|}{ Site Description } & \multicolumn{3}{|c|}{ FFG Family and Characteristics } & \multirow{2}{*}{\multicolumn{2}{|c|}{$\begin{array}{l}\text { Total } \\
\text { Family } \\
\text { Richness }\end{array}$}} \\
\hline B.A. & C.C. & Alk. & $\mathrm{pH}$ & Filterer & $\%$ & $\mathrm{mgDM} / \mathrm{m}^{2}$ & & \\
\hline 48 & 31 & 22.4 & 5.5 & ND & ND & ND & ND & ND \\
\hline 98 & 92 & 17.2 & 6.1 & ND & ND & ND & ND & ND \\
\hline 469 & 92 & 4.2 & 4.5 & Polycentropodidae & 100 & 1.2 & 09 & 01 \\
\hline 540 & 92 & 7.6 & 4.5 & Polycentropodidae & 100 & 1.0 & 10 & 01 \\
\hline 1043 & 84 & 8.3 & 5.8 & Polycentropodidae & 100 & 2.0 & 28 & 01 \\
\hline \multirow[t]{2}{*}{1225} & 54 & 8.9 & 5.7 & Polycentropodidae & 99 & 10.3 & 28 & 02 \\
\hline & & & & Hydropsychidae & 01 & 0.04 & 05 & \\
\hline \multirow[t]{3}{*}{1464} & 74 & 10.0 & 6.0 & Hydropsychidae & 56 & 2.1 & 07 & 03 \\
\hline & & & & Polycentropodidae & 38 & 1.4 & 32 & \\
\hline & & & & Simulidae & 06 & 0.2 & 11 & \\
\hline \multirow[t]{3}{*}{1640} & 44 & 66.7 & 6.4 & Isonychiidae & 72 & 39.3 & 12 & 03 \\
\hline & & & & Polycentropodidae & 18 & 9.9 & 81 & \\
\hline & & & & Hydropsychidae & 10 & 5.8 & 20 & \\
\hline \multirow[t]{3}{*}{5106} & 21 & 47.0 & 6.6 & Hydropsychidae & 62 & 9.2 & 45 & 03 \\
\hline & & & & Isonychiidae & 28 & 4.2 & 06 & \\
\hline & & & & Polycentropodidae & 10 & 1.5 & 23 & \\
\hline \multirow[t]{3}{*}{10300} & 07 & 39.7 & 6.2 & Polycentropodidae & 37 & 5.1 & 96 & 04 \\
\hline & & & & Isonychiidae & 37 & 5.0 & 02 & \\
\hline & & & & Hydropsychidae & 26 & 3.5 & 22 & \\
\hline
\end{tabular}

B.A. $=$ Basin Area (ha). C.C. $=$ Mean $(\mathrm{n}=10)$ Canopy Cover $(\%)$.

Alk. $=$ Mean $(\mathrm{n}=4-6)$ Alkalinity $\left(\mathrm{mg} / \mathrm{L} \mathrm{CaCO}_{3}\right) . \mathrm{pH}=\operatorname{Minimum}(\mathrm{n}=10) \mathrm{pH}$. 


\begin{tabular}{|c|c|c|c|c|c|c|c|c|}
\hline \multicolumn{4}{|c|}{ Site Description } & \multicolumn{4}{|c|}{ FFG Family and Characteristics } & \multirow{2}{*}{$\begin{array}{l}\text { Total } \\
\text { Family } \\
\text { Richness }\end{array}$} \\
\hline B.A. & C.C. & Alk. & $\mathrm{pH}$ & Filterer & $\%$ & $\mathrm{mgDM} / \mathrm{m}^{2}$ & $\mathrm{n}$ & \\
\hline \multirow[t]{4}{*}{48} & 31 & 22.4 & 5.5 & Hydropsychidae & 67 & 25.9 & 52 & 04 \\
\hline & & & & Polycentropodidae & 20 & 7.7 & 12 & \\
\hline & & & & Philopotamidae & 11 & 4.2 & 04 & \\
\hline & & & & Simulidae & 03 & 1.0 & 12 & \\
\hline \multirow[t]{4}{*}{98} & 92 & 17.2 & 6.1 & Polycentropodidae & 86 & 19.5 & 18 & 04 \\
\hline & & & & Simulidade & 10 & 2.2 & 79 & \\
\hline & & & & Hydropsychidae & 04 & 4.2 & 01 & \\
\hline & & & & Philopotamidae & 01 & 0.2 & 01 & \\
\hline \multirow[t]{2}{*}{469} & 92 & 4.2 & 4.5 & Hydropsychidae & 82 & 11.2 & 08 & 02 \\
\hline & & & & Polycentropodidae & 18 & 2.4 & 07 & \\
\hline \multirow[t]{2}{*}{540} & 92 & 7.6 & 4.5 & Polycentropodidae & 90 & 12.3 & 04 & 02 \\
\hline & & & & Hydropsychidae & 10 & 1.3 & 06 & \\
\hline 1043 & 84 & 8.3 & 5.8 & Polycentropodidae & 100 & 2.5 & 05 & 01 \\
\hline \multirow[t]{3}{*}{1225} & 54 & 8.9 & 5.7 & Polycentropodidae & 75 & 3.4 & 45 & 03 \\
\hline & & & & Hydropsychidae & 22 & 1.0 & 19 & \\
\hline & & & & Simulidae & 03 & 0.1 & 11 & \\
\hline \multirow[t]{3}{*}{1464} & 74 & 10.0 & 6.0 & Hydropsychidae & 67 & 7.4 & 80 & 03 \\
\hline & & & & Polycentropodidae & 30 & 3.3 & 37 & \\
\hline & & & & Simulidae & 03 & 0.3 & 109 & \\
\hline \multirow[t]{3}{*}{1640} & 44 & 66.7 & 6.4 & Hydropsychidae & 75 & 36.6 & 140 & 03 \\
\hline & & & & Isonychiidae & 21 & 10.3 & 06 & \\
\hline & & & & Polycentropodidae & 04 & 2.0 & 04 & \\
\hline \multirow[t]{2}{*}{5106} & 21 & 47.0 & 6.6 & Hydropsychidae & 73 & 23.3 & 78 & 02 \\
\hline & & & & Polycentropodidae & 27 & 8.6 & 17 & \\
\hline \multirow[t]{2}{*}{10300} & 07 & 39.7 & 6.2 & Hydropsychidae & 50 & 45.4 & 174 & 03 \\
\hline & & & & Polycentropodidae & 50 & 45.3 & 32 & \\
\hline
\end{tabular}

B.A. $=$ Basin Area (ha). C.C. $=$ Mean $(\mathrm{n}=10)$ Canopy Cover $(\%)$.

Alk. $=$ Mean $(\mathrm{n}=4-6)$ Alkalinity $\left(\mathrm{mg} / \mathrm{L} \mathrm{CaCO}_{3}\right) . \mathrm{pH}=\operatorname{Minimum}(\mathrm{n}=10) \mathrm{pH}$. 


\begin{tabular}{|c|c|c|c|c|c|c|c|c|}
\hline \multicolumn{4}{|c|}{ Site Description } & \multicolumn{3}{|c|}{ FFG Family and Characteristics } & \multirow{2}{*}{\multicolumn{2}{|c|}{$\begin{array}{l}\text { Total } \\
\text { Family } \\
\text { Richness }\end{array}$}} \\
\hline B.A. & C.C. & Alk. & $\mathrm{pH}$ & Predator & $\%$ & $\mathrm{mgDM} / \mathrm{m} 2$ & & \\
\hline 48 & 31 & 22.4 & 5.5 & ND & ND & ND & ND & ND \\
\hline 98 & 92 & 17.2 & 6.1 & ND & ND & ND & ND & ND \\
\hline \multirow[t]{3}{*}{469} & 92 & 4.2 & 4.5 & Perlodidae & 91 & 7.3 & 01 & 04 \\
\hline & & & & Chloroperlidae & 05 & 0.4 & 01 & \\
\hline & & & & Tabanidae & 03 & 0.3 & 01 & \\
\hline \multirow[t]{4}{*}{540} & 92 & 7.6 & 4.5 & Perlodidae & 75 & 5.8 & 01 & 06 \\
\hline & & & & Chloroperlidae & 23 & 1.7 & 15 & \\
\hline & & & & Ceratopogonidae & 01 & 0.1 & 43 & \\
\hline & & & & Tabanidae & 01 & 0.04 & 01 & \\
\hline \multirow[t]{4}{*}{1043} & 84 & 8.3 & 5.8 & Chloroperlidae & 65 & 6.2 & 84 & 05 \\
\hline & & & & Rhyacophilidae & 18 & 1.8 & 02 & \\
\hline & & & & Gomphidae & 13 & 1.2 & 10 & \\
\hline & & & & Empididae & 03 & 0.3 & 05 & \\
\hline \multirow[t]{2}{*}{1225} & 54 & 8.9 & 5.7 & Gomphidae & 64 & 13.1 & 01 & 05 \\
\hline & & & & Chloroperlidae & 36 & 7.4 & 100 & \\
\hline \multirow[t]{3}{*}{1464} & 74 & 10.0 & 6.0 & Gomphidae & 71 & 12.6 & 01 & 06 \\
\hline & & & & Chloroperlidae & 21 & 3.7 & 43 & \\
\hline & & & & Perlodidae & 07 & 1.3 & 01 & \\
\hline \multirow[t]{4}{*}{1640} & 44 & 66.7 & 6.4 & Chloroperlidae & 37 & 8.3 & 54 & 06 \\
\hline & & & & Corydalidae & 36 & 8.0 & 03 & \\
\hline & & & & Gomphidae & 26 & 5.9 & 05 & \\
\hline & & & & Empididae & 01 & 0.3 & 15 & \\
\hline \multirow[t]{6}{*}{5106} & 21 & 47.0 & 6.6 & Perlidae & 29 & 2.4 & 04 & 08 \\
\hline & & & & Corydalidae & 25 & 2.1 & 03 & \\
\hline & & & & Gomphidae & 20 & 1.7 & 03 & \\
\hline & & & & Chloroperlidae & 14 & 1.2 & 33 & \\
\hline & & & & Sialidae & 07 & 0.6 & 01 & \\
\hline & & & & Perlodidae & 05 & 0.5 & 33 & \\
\hline \multirow[t]{5}{*}{10300} & 07 & 39.7 & 6.2 & Corydalidae & 61 & 27.4 & 01 & 08 \\
\hline & & & & Gomphidae & 28 & 12.6 & 16 & \\
\hline & & & & Perlidae & 05 & 2.2 & 07 & \\
\hline & & & & Chloroperlidae & 04 & 1.7 & 17 & \\
\hline & & & & Perlodidae & 02 & 1.0 & 03 & \\
\hline
\end{tabular}

B.A. $=$ Basin Area (ha). C.C. $=$ Mean $(\mathrm{n}=10)$ Canopy Cover (\%).

Alk. $=$ Mean $(\mathrm{n}=4-6)$ Alkalinity $\left(\mathrm{mg} / \mathrm{L} \mathrm{CaCO}_{3}\right) . \mathrm{pH}=\operatorname{Minimum}(\mathrm{n}=10) \mathrm{pH}$. 


\begin{tabular}{|c|c|c|c|c|c|c|c|c|}
\hline \multicolumn{4}{|c|}{ Site Description } & \multicolumn{3}{|c|}{ FFG Family and Characteristics } & & \multirow{2}{*}{$\begin{array}{l}\text { Total } \\
\text { Family } \\
\text { Richness }\end{array}$} \\
\hline B.A. & C.C. & Alk. & $\mathrm{pH}$ & Predator & $\%$ & $\mathrm{mgDM} / \mathrm{m}^{2}$ & $\mathrm{n}$ & \\
\hline 48 & 31 & 22.4 & 5.5 & ND & ND & ND & ND & ND \\
\hline 98 & 92 & 17.2 & 6.1 & ND & ND & ND & ND & ND \\
\hline \multirow{5}{*}{469} & 92 & 4.2 & 4.5 & Ceratopogonidae & 53 & 0.4 & 59 & 05 \\
\hline & & & & Chloroperlidae & 27 & 0.2 & 02 & \\
\hline & & & & Perlodidae & 08 & 0.1 & 02 & \\
\hline & & & & Rhyacophilidae & 07 & 0.1 & 08 & \\
\hline & & & & Empididae & 05 & 0.04 & 03 & \\
\hline \multirow[t]{5}{*}{540} & 92 & 7.6 & 4.5 & Chloroperlidae & 56 & 2.9 & 14 & 06 \\
\hline & & & & Perlodidae & 34 & 1.5 & 09 & \\
\hline & & & & Ceratopogonidae & 06 & 0.3 & 25 & \\
\hline & & & & Rhyacophilidae & 04 & 0.2 & 06 & \\
\hline & & & & Gomphidae & 01 & 0.03 & 02 & \\
\hline \multirow[t]{5}{*}{1043} & 84 & 8.3 & 5.8 & Chloroperlidae & 74 & 6.7 & 100 & 05 \\
\hline & & & & Perlodidae & 11 & 1.0 & 02 & \\
\hline & & & & Gomphidae & 06 & 0.6 & 01 & \\
\hline & & & & Rhyacophilidae & 05 & 0.5 & 06 & \\
\hline & & & & Ceratopogonidae & 04 & 0.4 & 33 & \\
\hline \multirow[t]{4}{*}{1225} & 54 & 8.9 & 5.7 & Chloroperlidae & 92 & 6.9 & 52 & 05 \\
\hline & & & & Rhyacophilidae & 05 & 0.4 & 02 & \\
\hline & & & & Ceratopogonidae & 02 & 0.2 & 27 & \\
\hline & & & & Perlodidae & 01 & 0.1 & 01 & \\
\hline \multirow[t]{5}{*}{1464} & 74 & 10.0 & 6.0 & Chloroperlidae & 81 & 5.0 & 66 & 05 \\
\hline & & & & Ceratopogonidae & 10 & 0.6 & 25 & \\
\hline & & & & Rhyacophilidae & 07 & 0.4 & 22 & \\
\hline & & & & Perlodidae & 01 & 0.03 & 02 & \\
\hline & & & & Empididae & 01 & 0.03 & 02 & \\
\hline \multirow[t]{6}{*}{1640} & 44 & 66.7 & 6.4 & Corydalidae & 57 & 50.0 & 08 & 07 \\
\hline & & & & Perlidae & 19 & 16.7 & 04 & \\
\hline & & & & Gomphidae & 19 & 16.5 & 06 & \\
\hline & & & & Chloroperlidae & 03 & 3.0 & 29 & \\
\hline & & & & Perlodidae & 01 & 1.2 & 06 & \\
\hline & & & & Rhyacophilidae & 01 & 0.6 & 06 & \\
\hline \multirow[t]{6}{*}{5106} & 21 & 47.0 & 6.6 & Corydalidae & 41 & 11.4 & 23 & 09 \\
\hline & & & & Gomphidae & 37 & 10.3 & 05 & \\
\hline & & & & Perlodidae & 13 & 3.7 & 21 & \\
\hline & & & & Sialidae & 04 & 1.1 & 02 & \\
\hline & & & & Chloroperlidae & 04 & 1.0 & 18 & \\
\hline & & & & Rhyacophilidae & 01 & 0.2 & 26 & \\
\hline \multirow[t]{8}{*}{10300} & 07 & 39.7 & 6.2 & Gomphidae & 38 & 5.5 & 06 & 09 \\
\hline & & & & Corydalidae & 21 & 3.0 & 05 & \\
\hline & & & & Perlodidae & 16 & 2.3 & 07 & \\
\hline & & & & Chloroperlidae & 08 & 1.2 & 07 & \\
\hline & & & & Perlidae & 07 & 1.0 & 02 & \\
\hline & & & & Ceratopogonidae & 05 & 0.6 & 42 & \\
\hline & & & & Rhyacophilidae & 04 & 0.6 & 17 & \\
\hline & & & & Muscidae & 01 & 0.1 & 02 & \\
\hline
\end{tabular}

B.A. $=$ Basin Area (ha). C.C. $=$ Mean $(\mathrm{n}=10)$ Canopy Cover $(\%)$.

Alk. $=$ Mean $(\mathrm{n}=4-6)$ Alkalinity $\left(\mathrm{mg} / \mathrm{L} \mathrm{CaCO}_{3}\right) \cdot \mathrm{pH}=\operatorname{Minimum}(\mathrm{n}=10) \mathrm{pH}$. 
Site Description $\quad$ FFG Family and Characteristics

B.A. C.C. Alk. pH Predator $\%$

$\begin{array}{lllll}48 & 31 & 22.4 & 5.5 & \text { Perlodidae }\end{array}$

Gomphidae $\quad 21$

Chloroperlidae $\quad 16$

Rhyacophilidae $\quad 07$

Chloroperlidae

Perlodidae $\quad 46$

Gomphidae $\quad 01$

Rhyacophilidae 01

Ceratopogonidae 01

$\begin{array}{llllll}469 & 92 & 4.2 & 4.5 & \text { Perlodidae } & 73\end{array}$

Chloroperlidae $\quad 21$

Rhyacophilidae 04

Ceratopogonidae 02

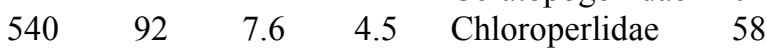

Perlodidae 23

Rhyacophilidae $\quad 18$

Empididae $\quad 01$

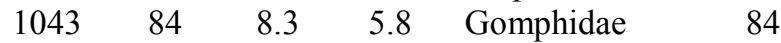

Chloroperlidae $\quad 16$

Perlodidae 01

$\begin{array}{lllll}1225 & 54 & 8.9 & 5.7 & \text { Chloroperlidae }\end{array}$

Perlidae 25

Rhyacophilidae $\quad 12$

Perlodidae 01

Gomphidae $\quad 01$

$\begin{array}{lllll}1464 & 74 & 10.0 & 6.0 & \text { Chloroperlidae } \\ 63\end{array}$

Perlodidae $\quad 33$

Rhyacophilidae 03

Ceratopogonidae 01

$\begin{array}{llllll}1640 & 44 & 66.7 & 6.4 & \text { Perlidae } & 37\end{array}$

Rhyacophilidae $\quad 30$

Corydalidae

Perlodidae

Aeshnidae

Chloroperlidae 05

Chloroperlidae $\quad 27$

Rhyacophilidae 21

Aeshnidae

Perlidae

Corydalidae

Athericidae

Sialidae
$\mathrm{mgDM} / \mathrm{m}^{2}$

45.1

16.7

12.9

5.3

22.9

20.6

0.6

0.4

0.2

2.6

0.7

0.1

0.1

4.1

1.6

1.3

0.04

31.5

5.9

0.3

27.9

11.3

5.3

0.6

0.5

11.0

5.8

0.5

0.2

45.1

36.0

13.1

12.6

7.0

6.4

15.6

12.6

10.0

3.1

2.8

2.3

0.6

0.3
Total

Family

Richness

06

02

80

03

110

34

03

01

17

03

21

05

03

102

09

02

01

01

82

02

158

01

08

03

02

126

09

35

11

05

93

03

07

01

108

14

211

26

02

01

01

01

01

07

04

05

04

06

04

08

11 
Fall Predator Functional Group continued.

Site Description $\quad$ FFG Family and Characteristics

Total

Family

\begin{tabular}{lccclcccc} 
B.A. & C.C. & Alk. & $\mathrm{pH}$ & Predator & $\%$ & $\mathrm{mgDM} / \mathrm{m}^{2}$ & $\mathrm{n}$ & Richness \\
\hline 10300 & 07 & 39.7 & 6.2 & Perlidae & 61 & 142.9 & 02 & 09 \\
& & & & Perlodidae & 22 & 52.1 & 12 & \\
& & & & Corydalidae & 08 & 18.9 & 03 & \\
& & & & Aeshnidae & 04 & 9.9 & 17 & \\
& & & & Rhyacophilidae & 03 & 7.8 & 18 & \\
& & & & Chloroperlidae & 01 & 1.5 &
\end{tabular}

B.A. $=$ Basin Area (ha). C.C. $=$ Mean $(\mathrm{n}=10)$ Canopy Cover $(\%)$.

Alk. $=$ Mean $(\mathrm{n}=4-6)$ Alkalinity $\left(\mathrm{mg} / \mathrm{L} \mathrm{CaCO}_{3}\right) . \mathrm{pH}=\operatorname{Minimum}(\mathrm{n}=10) \mathrm{pH}$. 